\title{
Sustainability on the urban scale: proposal of a structure of indicators for the Spanish context
}

\author{
Marta Braulio-Gonzalo*, María Dolores Bovea, María José Ruá \\ Department of Mechanical Engineering and Construction, Universitat Jaume I, Av. Sos Baynat s/n, 12071 \\ Castellón, Spain \\ E-mail addresses: \\ braulio@uji.es (M. Braulio-Gonzalo, *Corresponding author) \\ bovea@uji.es (M.D. Bovea) \\ rua@uji.es (M.J. Ruá).
}

\begin{abstract}
Some efforts to assess sustainability on the urban scale have been made and different tools for measuring the impact on and caused by cities have emerged. However, the sustainability concept varies from region to region, and indicators to measure it should be suitable for the context-specific conditions of the region under study. After doing a comprehensive review of the indicators included in 13 tools developed to assess urban sustainability of cities, this article proposes a new structure of indicators adapted to a Mediterranean city in Spain. The proposed structure is based on a two-level scheme that consists in 14 categories and 63 subcategories, which agglutinate urban sustainability indicators according to their purpose. This structure suggests a set of comprehensible qualitative and quantitative indicators that are easily applicable on neighbourhood or city scales. Given the similar features of Mediterranean countries in terms of environmental and socio-economic aspects, the proposed structure could be extrapolated to other countries with climatic and cultural similarities. Otherwise, the system is a useful tool in the decisionmaking process to help the different stakeholders involved in new urban developments and regeneration projects in existing neighbourhoods, such as developers, urban planners and public administrations.
\end{abstract}

\section{Keywords}

built environment; urban sustainability; assessment tool; urban indicator

\section{Highlights}

- Comprehensive review of 13 urban sustainability assessment tools

- Proposal of a two-level structure to cluster urban sustainability indicators

- Inclusion of sustainability criteria for urban planning projects and interventions

\section{Introduction}

While urban responses to climate change and impacts have been recently identified and recognised, the relationship between cities and climate change has been increasingly targeted by the research community (Castán and Bulkeley, 2013). Urban centres are now considered to form a vital part of the global impact response (UN-Habitat, 2011). Thus tools to measure the impact of urban ecosystems components are required (Dizdaroglu and Yigitcanlar, 2014) to assess urban sustainability in its three dimensions: environmental, social and economic.

The situation is not always straightforward since cities are complex and rigid systems, where their biological and physical complexities interact with each other. Existing conditions (e.g. urban planning, building blocks 
and zoning of uses) are not easy to change. However, cities must be able to adapt to external shocks and meet the changing demands of society in order to approach the resilient city concept (Pickett et al. 2014). Moreover, urban population growth and the rural exodus to cities have led to a rapid expansion of European cities in recent years, particularly in Spain. This has led to disorganised planning where efforts strongly focused on land use optimisation as an economic asset, instead of taking into account the conservation of those environmental and cultural issues (Rueda et al., 2007).

When a new district is projected, it is possible to conduct an accurate design with sustainable development premises from very early stages (Gil and Duarte, 2013). In contrast, the circumstances for existing neighbourhoods are quite different, where most physical conditions are static and cannot be easily modified. However, it is still possible to work on many aspects of such built neighbourhoods, which may greatly improve the livability and reduce the impact generated on both the environment and population.

It is necessary to do an analysis from the sustainability perspective to organise all the aspects surrounding the city and the interaction among them, and to thus identify the key topics that must be addressed in any new urban development or in existing neighbourhood intervention.

Since the emergence of the term Sustainable Development (Brundtland, 1987), many efforts have been made by the community to measure the level of sustainability of an urban system through indicators (OCDE, 2014). Since the mid-1990s, research into the urban context has focused on municipal strategies and policies, predominantly in North America and Europe, and many policy implementation challenges have been faced by local authorities (Bulkeley, 2010). The first indicators of sustainable development stemmed from a recommendation made by Agenda 21 (United Nations, 1995). This recommendation was to identify and develop indicators of sustainable development that could provide a solid basis for decision making at all levels (regional, national and international) and to also include the incorporation of a suitable set of these indicators into common databases that are widely accessible and regularly updated (UN Sustainable Development, 1998). The list of sustainability indicators included 134, where countries could make a selection when developing their own programmes. However, after participation and having implemented indicators in 22 countries in areas worldwide, it was concluded that not all the listed indicators were relevant for the globalisation of countries since they did not fully capture context-specific issues. Furthermore, as the list was too exhaustive, time restrictions lowered the level of achievement in consultations, and most countries prioritised monitoring indicators using relevant criteria, such as affordability, accessibility of data, usefulness and policy relevance. The need to develop a structure of urban sustainability indicators that adapt to a specific context in each region is clear, and many efforts towards this objective have been recently made through the development of different tools, which aim to analyse the urban sustainability of cities and neighbourhoods (Castanheira and Bragança, 2014).

The objective of this work was to develop a structure of indicators applicable to measure the sustainability of a Mediterranean city in Spain. To achieve this aim, a comprehensive review of tools previously developed internationally and nationally was done to identify those key issues that must be considered when proposing a structure of indicators that adapt to the Spanish context.

\section{Background}

Since the Building Research Establishment Environmental Assessment Method (BREAAM) was introduced in the UK in 1990 to focus on the environmental performance of buildings, different tools have been developed worldwide to assess sustainability of buildings (Haapio and Viitaniemi, 2008; Huedo and LópezMesa, 2013). Nowadays, however, efforts go further and the research community is interested in assessing 
the sustainability of larger areas that come close to the city scale. Thus it is necessary to not only focus on the assessment of the sustainability of buildings as an isolated element, but to also consider more complex aspects which relate them to their surroundings and the environment.

To date, some studies have suggested qualitative and quantitative indicators with a sustainable urban neighbourhood approach (Bourdic et al., 2012). Although other qualitative analyses have been conducted (Gil and Duarte, 2013; Haapio, 2012; Nguyen and Altan 2011), the first quantitative review was by Luederitz et al., (2013). This study sorted the literature indicators into 17 categories and counted the number of papers included in each one. However, not all the sustainability criteria were completely covered by these categories and the indicators included in each one have not been profoundly analysed. This paper aims to bridge this gap by proposing a set of categories that cover all the sustainability criteria based on the analysis of indicators published in the literature.

Different tools have been developed worldwide precisely for this aim. By way of example: Leadership in Energy and Environmental Design for Neighbourhood Development (LEED ND) in 2009 (US GBC, 2009a), Building Research Establishment Environmental Assessment Methodology (BREEAM Communities) in 2007 (BRE Global, 2011), Comprehensive Assessment System for Building Environmental Efficiency for Urban Development (CASBEE UD) in 2006 (IBEC, 2007), Haute Qualité Environnementale et Economique Réhabilitation (HQE2R) in 2001 (Blum, 2007), Ecocity in 2002 (Gaffron et al., 2005), Sustainable Community Rating (SCR) in 2007 (SCR, 2014), EarthCraft Communities (ECC) in 2003 (EarthCraft, 2014), SustainaBle uRban planning Decision support accounting for Urban mEtabolism (BRIDGE) in 2013 (Chrysoulakis et al., 2013) and Key Indicators for Territorial Cohesion and Spatial Planning (KITCASP) (Daly and González, 2013), among others.

Some efforts have also been made to compare these tools. Sharifi and Murayama (2013) compared seven tools (LEED ND, BREEAM Communities, CASBEE UD, HQE2R, Ecocity, SCR and ECC) to highlight the strengths and weaknesses of each one, made recommendations for improvements, proposed a set of themes and criteria that comprised all the indicators included in the above-mentioned tools, and determined the degree of emphasis to place on each theme. Later, Sharifi and Murayama (2014) carried out a crossevaluation of the LEED ND, CASBEE UD and BREEAM Communities in a case study whose goal was to compare results and propose changes to optimise these assessment tools. Similar conclusions were drawn by Bourdic et al. (2012), who concluded that BREEAM Communities, LEED ND and CASBEE UD revealed lack of robustness given the confusing use of qualitative and quantitative criteria, all of which are mixed in a single aggregated rating system. These authors proposed a new quantitative indicators system based on a morphologic approach, where mathematical formulas were used to assess the energy efficiency, social and environmental consequences of different urban forms. In the Spanish context, the VERDE tool was developed only to assess sustainability of buildings (Macías et al., 2010) and no other tool has been developed with a wider approach to assess sustainability on the urban scale. Nevertheless, there are publications in Spain which establish guidelines to follow for the implementation of sustainability criteria into Spanish cities, such as: Spanish White Paper on Sustainable Urban Planning (LB, 2010), Municipal Sustainability Indicator System (SMIS, 2010) and Indicators and Constraints System for Large and Medium Cities (CGYM, 2010). Besides, some indicators systems have been developed specifically for certain municipalities, such as: Special Plan for Environmental Sustainability Indicators for the Urban Development in Seville (SEV, 2007), Municipal Indicators System for Barcelona Provincial Council (BCN, 2009) and Sustainability Indicators for Bilbao (BIL, 2008). 


\section{Selection and description of the neighbourhood sustainability assessment tools under study}

Considering the literature review done, thirteen tools have been selected and analysed in depth in order to propose a common structure for the classification of sustainable urban indicators. Territorial (international, national and regional scale) and temporal (from 2005 to the present-day) criteria have been taken into account to choose the tools.

Three tools were selected at the international level, which are universally applicable (BREEAM Communities, LEED ND and CASBEE UD); two ad hoc developed tools at the European level (ECOCITY and Le Modele INDI-RU 2005, European Union (EU) projects); two other relevant and more recent EU-projects (BRIDGE and KITCASP) and five sets of indicators developed in Spain to be applied state-wide or more closely to regions or provinces (LB, SIDS, CGYM, SEV, BCN, BIL). Table 1 presents the basic characteristics of each tool: developer, year of introduction, country of origin and their potential application to other countries, scope, methodology, and third party (if needed, is an accredited assessor to implement the tool) and rating system. 
Table 1. Main characteristics of the urban sustainability assessment tools under study

\begin{tabular}{|c|c|c|c|c|c|c|c|c|}
\hline Tool & Developer & Country/Region & $\begin{array}{l}\text { Year } \\
\text { public. }\end{array}$ & $\begin{array}{l}\text { Last } \\
\text { version }\end{array}$ & Reference & Scope & $\begin{array}{l}\text { Accredited } \\
\text { Assessor }\end{array}$ & Rating system \\
\hline LEED ND & $\begin{array}{l}\text { United States Green Building Council (USGBC) } \\
\text { Congress for the New Urbanism (CNU) } \\
\text { Natural Resources Defense Council (NRDC) }\end{array}$ & $\begin{array}{l}\text { US } \\
\text { (adaptable to other } \\
\text { regions over the world) }\end{array}$ & 2006 & 2009 & $\begin{array}{l}\text { US GBC (2009a) } \\
\text { US GBC (2009b) }\end{array}$ & $\begin{array}{l}\text { The whole neighbourhood } \\
\text { including residential and } \\
\text { non-residential buildings. } \\
\text { New developments and } \\
\text { regeneration projects. }\end{array}$ & Optional & $\begin{array}{l}\text { Platinum } \geq 80 \\
\text { Gold } \geq 60 \\
\text { Silver } \geq 50 \\
\text { Certified } \geq 40\end{array}$ \\
\hline BREEAM Communities & Building Research Establishment Ltd (BRE Global) & $\begin{array}{l}\text { UK } \\
\text { (adaptable to other } \\
\text { regions over the world) }\end{array}$ & 2007 & 2011 & $\begin{array}{l}\text { BRE Global } \\
\text { (2011a) } \\
\text { BRE Global } \\
\text { (2011b) }\end{array}$ & $\begin{array}{l}\text { Urban scale including } \\
\text { residential and non- } \\
\text { residential buildings, new } \\
\text { developments and } \\
\text { regeneration projects }\end{array}$ & Required & $\begin{array}{l}\text { Outstanding } \geq 85 \\
\text { Excellent } \geq 70 \\
\text { Very Good } \geq 55 \\
\text { Good } \geq 40 \\
\text { Pass } \geq 25 \\
\text { Unclassified }<25\end{array}$ \\
\hline CASBEE UD & $\begin{array}{l}\text { Japan Sustainable Building Consortium (JSBC) } \\
\text { Japan Green Building Council (JaGBC) }\end{array}$ & $\begin{array}{l}\text { Japan } \\
\text { (applicable to Japan and } \\
\text { other Asian regions) }\end{array}$ & 2006 & 2007 & IBEC (2007) & $\begin{array}{l}\text { Groups of buildings and } \\
\text { outdoor surrounding spaces } \\
\text { (excluding the interior of } \\
\text { buildings). } \\
\text { New and regeneration } \\
\text { projects }\end{array}$ & Required & $\begin{array}{l}\text { Excellent (BEE } \geq 3) \\
\text { Very Good }(B E E \geq 1.5) \\
\text { Good (BEE } \geq 1) \\
\text { Fairly Poor }(B E E \geq 0.5) \\
\text { Poor (BEE }<0.5)\end{array}$ \\
\hline ECOCITY & $\begin{array}{l}\text { European Commission } \\
\text { Ph. Gaffron, G. Huismans y F. Skala (Coordinators) }\end{array}$ & $\begin{array}{l}\text { Europe (7 European } \\
\text { countries: Austria, Spain, } \\
\text { Hungary, Finland, } \\
\text { Slovakia, Germany, Italy) } \\
\text { (applicable in European } \\
\text { context) }\end{array}$ & $\begin{array}{l}2002- \\
2005\end{array}$ & 2005 & $\begin{array}{l}\text { Gaffron et al. } \\
\text { (2005) } \\
\text { Gaffron et al. } \\
(2008)\end{array}$ & $\begin{array}{l}\text { Neighbourhood and city } \\
\text { scale } \\
\text { Applicable to European } \\
\text { context }\end{array}$ & $\begin{array}{l}\text { The system } \\
\text { provides } \\
\text { optional } \\
\text { consultancy, but } \\
\text { not compulsory }\end{array}$ & - \\
\hline Le Modele INDI-RU 2005 & $\begin{array}{l}\text { SUDEN (Association européene pour un développement } \\
\text { urbain durable). } \\
\text { The coordinators of the project SUSI-Man are: } \\
\text {-Catherine Charlot-Valdieu, La CALADE (Conseil et } \\
\text { Recherche en Développement Durable) } \\
\text {-Philippe Outrequin, SUDEN }\end{array}$ & $\begin{array}{l}\text { France } \\
\text { (adaptable to other } \\
\text { regions over the world) }\end{array}$ & 2005 & 2010 & $\begin{array}{l}\text { Charlot-Valdieu } \\
\text { and Outrequin } \\
\text { (2005) }\end{array}$ & $\begin{array}{l}\text { Neighbourhood and city } \\
\text { scale }\end{array}$ & - & - \\
\hline $\begin{array}{l}\text { The BRIDGE project } \\
\text { (SustainaBle uRban planning } \\
\text { Decision support } \\
\text { accountinG for Urban } \\
\text { mEtabolism) }\end{array}$ & $\begin{array}{l}\text { European Community's Seventh Framework Programme } \\
\text { (FP7/2007-2013). } 14 \text { partners: } \\
\text { Foundation for research and technology- Hellas } \\
\text { King'S College London } \\
\text { Consiglio Nazionale delle Ricerche } \\
\text { Instytut Ekologii Terenow Uprzamyslowionych } \\
\text { Technical University of Madrid } \\
\text { University of Aveiro } \\
\text { University of Basel } \\
\text { Trinity College Dublin } \\
\text { University of Helsinki } \\
\text { National and Kapodistrian University of Athens } \\
\text { Centro Euro-Mediterraneo per I Cambiamenti Climatici } \\
\text { Meteo-France Centre National de Recherches }\end{array}$ & $\begin{array}{l}\text { Europe (5 European cities } \\
\text { involved: Helsinki, Athens, } \\
\text { London, Firenze, Gliwice) }\end{array}$ & 2013 & 2013 & $\begin{array}{l}\text { Chrysoulakis et } \\
\text { al. (2013) } \\
\text { González et al. } \\
\text { (2013) }\end{array}$ & $\begin{array}{l}\text { Neighbourhood and city } \\
\text { scale }\end{array}$ & - & - \\
\hline
\end{tabular}


ondon

Daly et al. 12

Universitat Politècnica de Catalunya

University of Akureyri Research Centre

Vidzeme University of Applied Sciences

Ministerio de Vivienda 
A more in-depth analysis of each tool allowed the identification of the structure of indicators considered in each one to evaluate the sustainability of an urban area. Table 2 shows how the tools are structured and the nature of the indicators included according to the following aspects:

- Structure of the indicators: the way the indicators are organised in the tool is not unique, but each one uses a different way, which can involve dimensions of sustainability, categories, subcategories, themes, objectives, measures, strategies, etc., until the lowest level, which are the indicators.

- Type of indicator: depending on the inherent characteristics of the indicators, they can be quantitative or qualitative.

- Number of indicators: the exhaustive list of indicators included in each tool can be found in Supplementary Information 1.

- Weighting method: the way the values of the indicators are aggregated.

Table 2. The structure of indicators of the urban sustainability assessment tools analysed

\begin{tabular}{|c|c|c|c|c|c|}
\hline Tool & Structure & Indicator type & No. Indicators & Pre-requisites $^{3}$ & $\begin{array}{l}\text { Indicator weighting } \\
\text { method }\end{array}$ \\
\hline LEED ND & $\begin{array}{l}5 \text { categories } \\
44 \text { indicators }\end{array}$ & Quantitative & 56 & $\begin{array}{l}\text { Includes } 12 \text { pre-requisites in the } \\
\text { categories (except Innovation), } \\
\text { to obtain the certificate. } \\
\text { ( } 21 \% \text { mandatory) }\end{array}$ & $\begin{array}{l}\text { No different score } \\
\text { depending on the region }\end{array}$ \\
\hline $\begin{array}{l}\text { BREEAM } \\
\text { Communities }\end{array}$ & $\begin{array}{l}9 \text { categories } \\
63 \text { Indicators }\end{array}$ & Quantitative & $\begin{array}{l}62+1 \\
\text { (innovation) }\end{array}$ & $\begin{array}{l}\text { Includes } 15 \text { pre-requisites in } \\
\text { some of the categories } \\
\text { (obtaining at least } 1 \text { point), to } \\
\text { obtain the certificate. } \\
\text { ( } 24 \% \text { of the indicators } \\
\text { mandatory, and } 8 \% \text { of the } \\
\text { score/points mandatory) }\end{array}$ & $\begin{array}{l}\text { Different score } \\
\text { depending on the UK } \\
\text { region where the tool is } \\
\text { implemented (London, } \\
\text { South East, South West, } \\
\text { North East, North West, } \\
\text { East Mids, West Mids, } \\
\text { East England) }\end{array}$ \\
\hline CASBEE UD & $\begin{array}{l}6 \text { categories (in two } \\
\text { sections: } \mathrm{Q}^{1} \text { and } \mathrm{L}^{2} \text { ), } \\
31 \text { sub- categories } \\
82 \text { indicators }\end{array}$ & Quantitative & 82 & $\begin{array}{l}\text { No pre-requisites included. } \\
\text { ( } 0 \% \text { mandatory) }\end{array}$ & $\begin{array}{l}\text { Different score } \\
\text { depending on the } \\
\text { location where the tool } \\
\text { is implemented (city- } \\
\text { centre or general) }\end{array}$ \\
\hline ECOCITY & $\begin{array}{l}5 \text { areas } \\
18 \text { themes } \\
39 \text { objectives } \\
186 \text { measures }\end{array}$ & Quantitative & 189 & $\begin{array}{l}\text { No pre-requisites included. } \\
\text { (0\% mandatory) }\end{array}$ & - \\
\hline $\begin{array}{l}\text { Le Modele INDI-RU } \\
2005\end{array}$ & $\begin{array}{l}5 \text { objectives } \\
21 \text { sub-objectives } \\
73 \text { indicators }\end{array}$ & Quantitative & 73 & $\begin{array}{l}\text { No pre-requisites included. } \\
\text { (0\% mandatory) }\end{array}$ & - \\
\hline BRIDGE & $\begin{array}{l}3 \text { dimensions } \\
12 \text { objectives } \\
28 \text { indicators }\end{array}$ & Quantitative & 28 & $\begin{array}{l}\text { No pre-requisites included. } \\
\text { ( } 0 \% \text { mandatory) }\end{array}$ & - \\
\hline KITCASP & $\begin{array}{l}4 \text { policy themes } \\
20 \text { indicators }\end{array}$ & Quantitative & 20 & $\begin{array}{l}\text { No pre-requisites included. } \\
\text { ( } 0 \% \text { mandatory) }\end{array}$ & - \\
\hline LB & $\begin{array}{l}7 \text { criteria } \\
19 \text { strategies } \\
93 \text { indicators }\end{array}$ & Qualitative & 93 & $\begin{array}{l}\text { No pre-requisites included. } \\
\text { ( } 0 \% \text { mandatory) }\end{array}$ & - \\
\hline SMIS & $\begin{array}{l}6 \text { areas } \\
13 \text { sub-areas } \\
39 \text { indicators }\end{array}$ & Quantitative & 39 & $\begin{array}{l}\text { No pre-requisites included. } \\
\text { ( } 0 \% \text { mandatory) }\end{array}$ & - \\
\hline CGYM & $\begin{array}{l}7 \text { areas } \\
18 \text { sub-areas } \\
52 \text { indicators }\end{array}$ & Quantitative & 52 & $\begin{array}{l}\text { No pre-requisites included. } \\
\text { ( } 0 \% \text { mandatory) }\end{array}$ & - \\
\hline SEV & $\begin{array}{l}7 \text { areas } \\
44 \text { indicators }\end{array}$ & Quantitative & 44 & $\begin{array}{l}\text { No pre-requisites included. } \\
\text { (0\% mandatory) }\end{array}$ & - \\
\hline $\mathrm{BCN}$ & $\begin{array}{l}4 \text { categories } \\
13 \text { indicators }\end{array}$ & Quantitative & 13 & $\begin{array}{l}\text { No pre-requisites included. } \\
\text { ( } 0 \% \text { mandatory) }\end{array}$ & - \\
\hline BIL & $\begin{array}{l}12 \text { categories } \\
34 \text { indicators }\end{array}$ & Quantitative & 34 & $\begin{array}{l}\text { No pre-requisites included. } \\
\text { (0\% mandatory) }\end{array}$ & - \\
\hline
\end{tabular}

${ }^{1} \mathrm{Q}$ : Environmental quality in urban development; ${ }^{2} \mathrm{~L}$ : Environmental load in urban development

${ }^{3}$ Pre-requisites are the mandatory requirements to be implemented to obtain certification of the tool/system 
The reality of cities can vary vastly from one country to another depending on factors such as location, weather conditions, and the socio-economic context, which includes these cultural issues. A city in, for instance, the United States (US) would not be comparable where it is advocated for a dispersed city model with a European city, and where the consolidated model is a compact mixed-use city (Rueda, 2007). Thus not all tools are valid in all regions of the world. So formulated tools must exist that adapt to the context, planning, the population, the culture and tradition, as particular features of a given environment.

\section{Comparison of the indicators of the analysed tools}

\subsection{A common structure for comparison and classification}

Prior to comparing the indicators used in each tool, it is necessary to define a common structure as each tool uses a different classification system and a distinct nomenclature. To deal with this, the first step was to form a two-level structure of categories and subcategories with their corresponding objective. To attain this, the structures of the indicators proposed in the literature were thoroughly reviewed. Sharifi and Murayama (2013) proposed the following categories: "resources and environment", "transportation", "social", "economic", "location and site selection", "pattern and design", "innovation", and subdivided some of them into several criteria. Luederitz et al. (2013) set out 11 categories related to the principles of sustainability: "function", "structure", "context", "leakage effects", "socio-ecological system integrity", "livelihood sufficiency and opportunity", "intra-generational equity", "inter-generational equity", "resource maintenance and efficiency", "socio-ecological civility and democratic governance", and "precaution and adaptation". Finally, Bourdic et al. (2012) proposed a set of quantitative indicators, which they distributed into nine context-specific categories: "land use", "mobility", "water", "biodiversity", "equity", "economy", "waste", "culture/well-being", and "energy and bioclimatic".

In all these ratings, categories are generally defined and each can include all sorts of indicators with different aims. This study, however, proposes a two-level structure, 14 categories and 69 subcategories, according to the findings from the review in Section 3 and Supplementary Information 1, as Figure 1 shows.

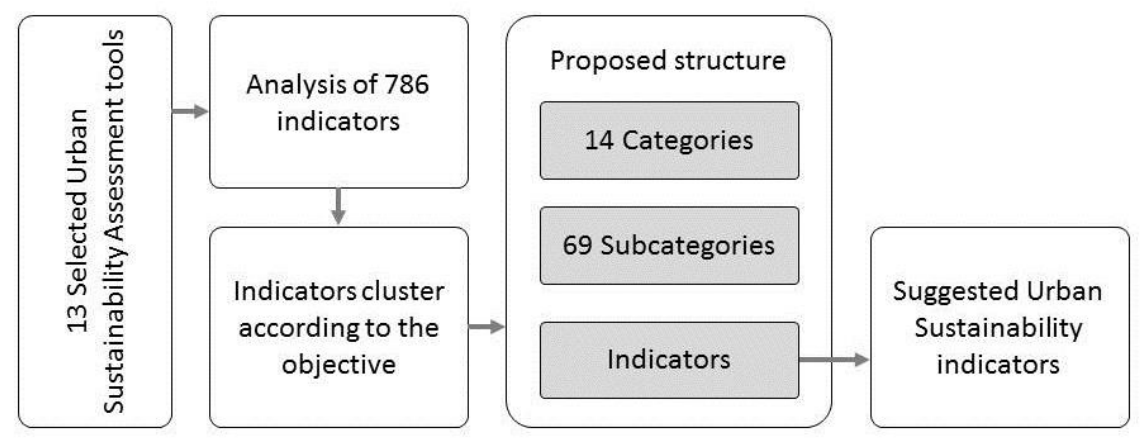

Figure 1. Methodological approach applied for proposing a structure of indicators for the Spanish context

The proposed structure of categories and subcategories, and the objective that the latter ones involve, are shown in Table 3.

Table 3. The two-level structure of categories and subcategories

\begin{tabular}{lll}
\hline Category & Subcategory & Objective \\
\hline Site and soil & Weather and site conditions & Harness the optimal conditions (topography, prevailing winds, sunlight) \\
& Land occupation & Encourage efficient land use \\
& Soil and heritage reuse and conservation & Encourage reuse of existing land and abandoned buildings
\end{tabular}


Compact city vs dispersed city (Rueda, 2007)

\begin{tabular}{ll}
\hline Urban & Design and quality of public space \\
morphology & Mixed-used development \\
& Equipment
\end{tabular}

Promote multi-family building in front of the detached (Ghosh and Vale, 2009) Ensure proper design of the city

Equipment

Encourage mixed-use buildings (residential, commercial, etc.)

Universal design and architectural barriers Provide neighbourhood with schools, healthcare facilities, commercial activities, etc.

Parking space

Safety, health and hygiene

Ensure that urban elements are usable by all people, even with disabilities Reduce parking spaces for private vehicles

Eliminate risks and ensure public safety

\begin{tabular}{lll}
\hline $\begin{array}{l}\text { Mobility and } \\
\text { transport }\end{array}$ & Distances reduction and private vehicle use & $\begin{array}{l}\text { Encourage compact city, reduce commuting time (Zhao et al., 2014) and improve } \\
\text { walking routes }\end{array}$ \\
& Public transport and other sustainable & Encourage the use of public transport and cycling and improving connections
\end{tabular}

alternatives

Efficiency of public transport

Efficiently use energy for transportation and promote compact forms (Byrd and Ho, 2012

Transport management

Improve logistics system and provide information to citizens on mobility

$\begin{array}{ll}\text { Nature and } & \text { Green areas } \\ \text { biodiversity } & \text { Urban farming and food }\end{array}$

Natural resources

Species biodiversity

Architectural elements with vegetation

Provide neighbourhoods with greenery and vegetation corridors

Integrating organic agriculture for own consumption or sale without intermediaries

Prevent the destruction of natural habitats of flora and fauna

Conserve biodiversity

Include vegetation on roofs and facades of buildings

Building and Fulfilment of standards and regulations

housing Building renovation and adaptation of use

Building resource efficiency

Building energy demand

Bioclimatic building design

Promote the use of environmental certification signs in buildings

Promote energy refurbishment of existing buildings and the adaptation of use

Perform a controlled use of resources in households

Design buildings with high energy efficiency to reduce energy demand (Okeil,

2010)

Condition of buildings naturally harnessing good microclimatic environmental

conditions (sunlight, natural ventilation and lighting)

Diversity of housing

Maintenance of buildings

Ensure diversity of housing according to status of occupants and size

Reduce the need for building maintenance

\begin{tabular}{ll}
\hline Energy & Sunlight and shadows \\
& Bioclimatic urban design \\
& Urban heat island \\
& Energy efficiency of facilities and monitoring \\
& Renewable energy \\
& Energy supply \\
& Energy consumption \\
\hline Water & Water consumption
\end{tabular}

Rainwater and wastewater management Mitigate solar obstructions in winter and provide protection and vegetation in summer

Condition urban spaces harnessing optimal microclimatic environmental conditions (sunlight, natural ventilation and lighting)

Mitigate "heat island" effect in cities

Improve energy efficiency (district heating, cooling and cogeneration plants in the neighbourhood)

Implement renewable energy to promote energy self-sufficiency

Secure energy supplies and encourage local energy production to limit external energy dependency

Quantify the energy consumption

Reduce water consumption through water-saving devices in sanitary appliances

Avoid losses in distribution networks

Enhancing water self-sufficiency

Reuse rainwater for irrigation, laundry, car washing and toilet flushing

Water quality

Materials Low-impact materials

Avoid water contamination and infiltration of other polluted waters

\begin{tabular}{|c|c|c|}
\hline \multirow[t]{4}{*}{ Materials } & Low-impact materials & $\begin{array}{l}\text { Use materials with low environmental impact during their life cycle (manufacture, } \\
\text { implementation and demolition) } \\
\text { Use materials with high durability and inventariables }\end{array}$ \\
\hline & Certified reference materials & Use materials with environmental labelling that provides reliable information \\
\hline & Reused and recycled materials & Minimize the use of materials and promoting the use of recycled / reused \\
\hline & Local materials & Encourage the use of local materials to reduce the impact caused by transport \\
\hline \multirow[t]{2}{*}{ Waste } & Minimising waste production & Minimize waste production \\
\hline & Waste treatment & Waste treatment \\
\hline \multirow[t]{6}{*}{ Pollution } & Soil & Prevent soil pollution \\
\hline & Air & Prevent soil pollution and ensure air quality \\
\hline & Water & Prevent soil pollution and ensure water quality \\
\hline & Noise & Prevent noise pollution \\
\hline & Light & Prevent light pollution \\
\hline & Resources and others & Prevent natural resources pollution and other pollution sources \\
\hline \multirow[t]{3}{*}{ Social aspect } & Social cohesion and mixed neighbourhoods & $\begin{array}{l}\text { Encourage mixed population of different age, origin and purchasing power, to } \\
\text { avoid the risk of poverty and social exclusion }\end{array}$ \\
\hline & Citizen participation & $\begin{array}{l}\text { Consider the views of citizens by local authorities in decision-making processes } \\
\text { Increase the level of satisfaction of the population }\end{array}$ \\
\hline & Civil association & Promote the association and visibility of citizens \\
\hline
\end{tabular}




\begin{tabular}{|c|c|c|}
\hline & Affordable housing & $\begin{array}{l}\text { Make available to the citizen affordable housing in all neighbourhoods through } \\
\text { housing development with state subsidy } \\
\text { Tackle fuel poverty }\end{array}$ \\
\hline & Education & Reduce the rate of truancy and delinquency in schools \\
\hline \multirow{13}{*}{$\begin{array}{l}\text { Economic } \\
\text { aspect }\end{array}$} & \multirow[t]{4}{*}{ Local, social and green jobs } & Hire local staff with different skill levels \\
\hline & & Create jobs next to residential areas to reduce commuting \\
\hline & & Encourage the marketing of local products \\
\hline & & Encourage economic exchange with the rural world \\
\hline & Employment rates & Measure employment and unemployment rate \\
\hline & \multirow[t]{3}{*}{ New business and investment } & Attract new businesses to neighbourhoods \\
\hline & & Encourage new business through the granting of loans \\
\hline & & Boost the local economy \\
\hline & \multirow[t]{3}{*}{ Quality of employment } & $\begin{array}{l}\text { Promote the smooth operation of small and medium enterprises (mixed-use in } \\
\text { the neighbourhood) }\end{array}$ \\
\hline & & $\begin{array}{l}\text { Provide information to citizens and companies about business available in the } \\
\text { neighbourhood }\end{array}$ \\
\hline & & Integrate environmental activity in the municipality \\
\hline & Tourism & Revitalize tourism \\
\hline & Return on investment and affordable costs & Assess investment and benefits that businesses involve \\
\hline \multirow{12}{*}{$\begin{array}{l}\text { Management } \\
\text { and institution }\end{array}$} & \multirow[t]{3}{*}{ Institutional management } & Encourage cooperation procedures between administrations \\
\hline & & Assist in implementation of Agenda 21 \\
\hline & & Seek alternative models for funding green infrastructure \\
\hline & Process management & $\begin{array}{l}\text { Implement certified management systems (ISO 9001, ISO 14001) to improve the } \\
\text { quality of procedures }\end{array}$ \\
\hline & Administrative transparency & Ensure administrative transparency in the processes of political decision-making \\
\hline & \multirow[t]{3}{*}{ Knowledge and information management } & Ensure good citizen information \\
\hline & & Develop reports that provide objective data \\
\hline & & Generate communication channels between institutions and citizens \\
\hline & $\begin{array}{l}\text { Information and Communications Technology } \\
\text { (ICT) }\end{array}$ & Incorporate ICT and ensure citizen access \\
\hline & Investment on activities for society & $\begin{array}{l}\text { Quantify the municipal spending in activities that reverse in society (actions on } \\
\text { the environment, social policy, solidarity and culture) }\end{array}$ \\
\hline & Environmental education & $\begin{array}{l}\text { Raise public awareness on issues such as energy and water consumption, use of } \\
\text { transport and waste management }\end{array}$ \\
\hline & Regulations to improve the sustainability & $\begin{array}{l}\text { Implement rate systems or incentives that help to regulate the habits of citizens } \\
\text { (discounted parking rates for the use of public transport, subsidies for the } \\
\text { renovation of buildings, or taxes for parking in city centres) }\end{array}$ \\
\hline Innovation & Innovation & Implement innovative solutions in different urban areas \\
\hline
\end{tabular}

Table 3 provides each category divided into subcategories, which are evaluated by a set of indicators (at least one) to help to measure the degree of fulfilment of the objective of the subcategory by an urban area. The list of indicators in each subcategory is reported in Supplementary Information 2.

When we look at the proposed structure in depth, it is noteworthy that many categories relate with each other. For example, the topic of "energy" is closely related to "mobility and transport", and also to "urban morphology", which determines the type of buildings and, therefore, their energy performance.

As concluded from Tables S2.1-S2.14 in Supplementary Information 2, the aspects that are more strongly related to other categories are "site and soil" and "urban morphology" as the design of a city shapes many physical, environmental and socio-economic aspects. Furthermore, these two first categories are closely linked. This is because both refer to the physical conditions of the environment, and determine important conditions such as location, climate, urban design, compactness and mixed use, among others.

"Mobility and transport" is closely related to urban layout because the city structure determines the distances people have to travel from home to school, work or shopping areas, which condition accessibility (Gaffron et al., 2008). The results of the study conducted by Zhao et al. (2014) reveal the close relationship between the compactness of the city and the time that residents spend commuting. It also indicates that a high rate of urbanisation without adequate planning has contributed to poor compactness of cities which has, consequently, led to longer commuting times. The relationship between both aspects is so close that 
the SEV tool proposes a unique theme to address urban morphology and transport issues across the "public space and mobility" category.

In relation to the "energy" category, the urban structure determines the type of buildings that can be built in an urban area. Accordingly, building types and morphology are very significant aspects for the energy efficiency performance of buildings (Okeil, 2010), the electricity used (Wilson, 2013) and greenhouse gas emissions. In their study, Makido et al. (2012) demonstrated that compact and tall buildings provide better energy efficiency results on a neighbourhood scale, while detached houses provide worse results.

The "building and housing" category is another aspect that relates closely to others since urban sustainability necessarily implies sustainability in the buildings making up the city. On a smaller scale, building sustainability is achieved through many intrinsic aspects of the building; e.g., "energy", "water", "materials", "waste", "pollution" and the "social aspect".

"Urban morphology" is also related to socio-economic aspects. Strong city compactness cuts distances among citizens and promotes relations among them, which encourages associations. The mixed use of residential and commercial uses in the same district also attracts new businesses to the area, which helps make the local economy more dynamic.

"Management and institution" is very important to ensure the smooth functioning of society. Good management and administrative transparency are necessary to ensure objectivity during the process of diagnosing, decision making, drafting and approving urban plans, and also while integrating Agenda 21.

Finally, "innovation" positively evaluates the implementation of innovative solutions in different aspects of urban sustainability. However, no specific correlations were identified between this category and others.

One conclusion drawn from this discussion is indicated in Table 4, which shows the level of relationship among the 14 categories proposed in this study.

Table 4. The level of relationship among the 14 proposed categories

\begin{tabular}{|c|c|c|c|c|c|c|c|c|c|c|c|c|c|c|}
\hline Category & SS & UM & MT & NB & $\mathrm{BH}$ & $E$ & Wr & $M$ & Ws & $P$ & SA & EA & $\mathrm{Ml}$ & I \\
\hline \multicolumn{15}{|l|}{ Site and soil (SS) } \\
\hline Urban morphology (UM) & $\bullet \bullet$ & & & & & & & & & & & & & \\
\hline Mobility and transport (MT) & $\bullet \bullet$ & $\bullet \bullet$ & & & & & & & & & & & & \\
\hline Nature and biodiversity (NB) & $\bullet \bullet$ & $\bullet$ & - & & & & & & & & & & & \\
\hline Building and housing $(\mathrm{BH})$ & $\bullet \bullet$ & $\bullet \bullet$ & - & $\bullet$ & & & & & & & & & & \\
\hline Energy (E) & $\bullet \bullet$ & $\bullet \bullet$ & $\bullet \bullet$ & $\bullet$ & $\bullet \bullet$ & & & & & & & & & \\
\hline Water (Wr) & $\bullet$ & - & - & $\bullet$ & $\bullet \bullet$ & $\bullet$ & & & & & & & & \\
\hline Materials (M) & $\bullet$ & - & $\bullet$ & $\bullet$ & $\bullet \bullet$ & $\bullet$ & - & & & & & & & \\
\hline Waste (Ws) & $\bullet$ & - & - & & $\bullet \bullet$ & - & - & $\bullet$ & & & & & & \\
\hline Pollution (P) & $\bullet$ & - & $\bullet$ & $\bullet$ & $\bullet \bullet$ & $\bullet$ & $\bullet \bullet$ & $\bullet$ & $\bullet$ & & & & & \\
\hline Social aspect (SA) & - & $\bullet$ & - & - & $\bullet$ & - & - & - & - & - & & & & \\
\hline Economic aspect (EA) & - & $\bullet$ & - & - & - & - & - & - & - & - & $\bullet$ & & & \\
\hline Management and institution (MI) & - & $\bullet$ & $\bullet$ & - & - & $\bullet$ & $\bullet$ & - & $\bullet$ & $\bullet$ & $\bullet \bullet$ & $\bullet \bullet$ & & \\
\hline Innovation (I) & - & - & - & - & - & - & - & - & - & - & - & - & - & \\
\hline
\end{tabular}

$[\bullet \bullet$ Strong relationship; [•] Medium relationship; [-] No relationship 


\subsection{Comparative analysis}

This section aims to analyse the indicators proposed for all 13 tools and per category and subcategory indicators. In order to determine which aspects are the most and least discussed in the analysed tools, and to be able to compare them all, the number of indicators in each category and subcategory is determined. The results are shown in Figure 2 and Figure 3, respectively.

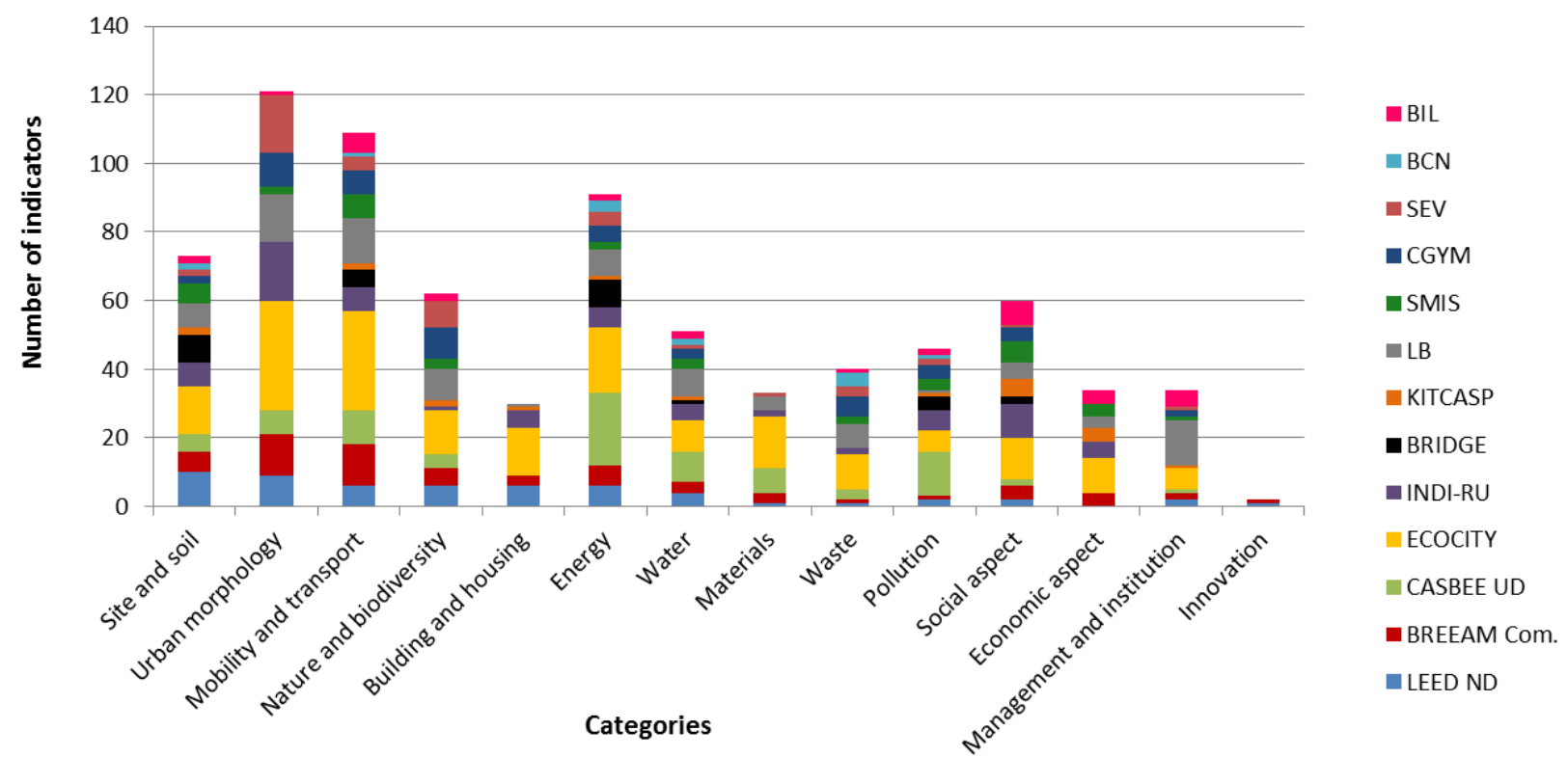

Figure 2. Number of indicators that each tool confers to the 14 study categories
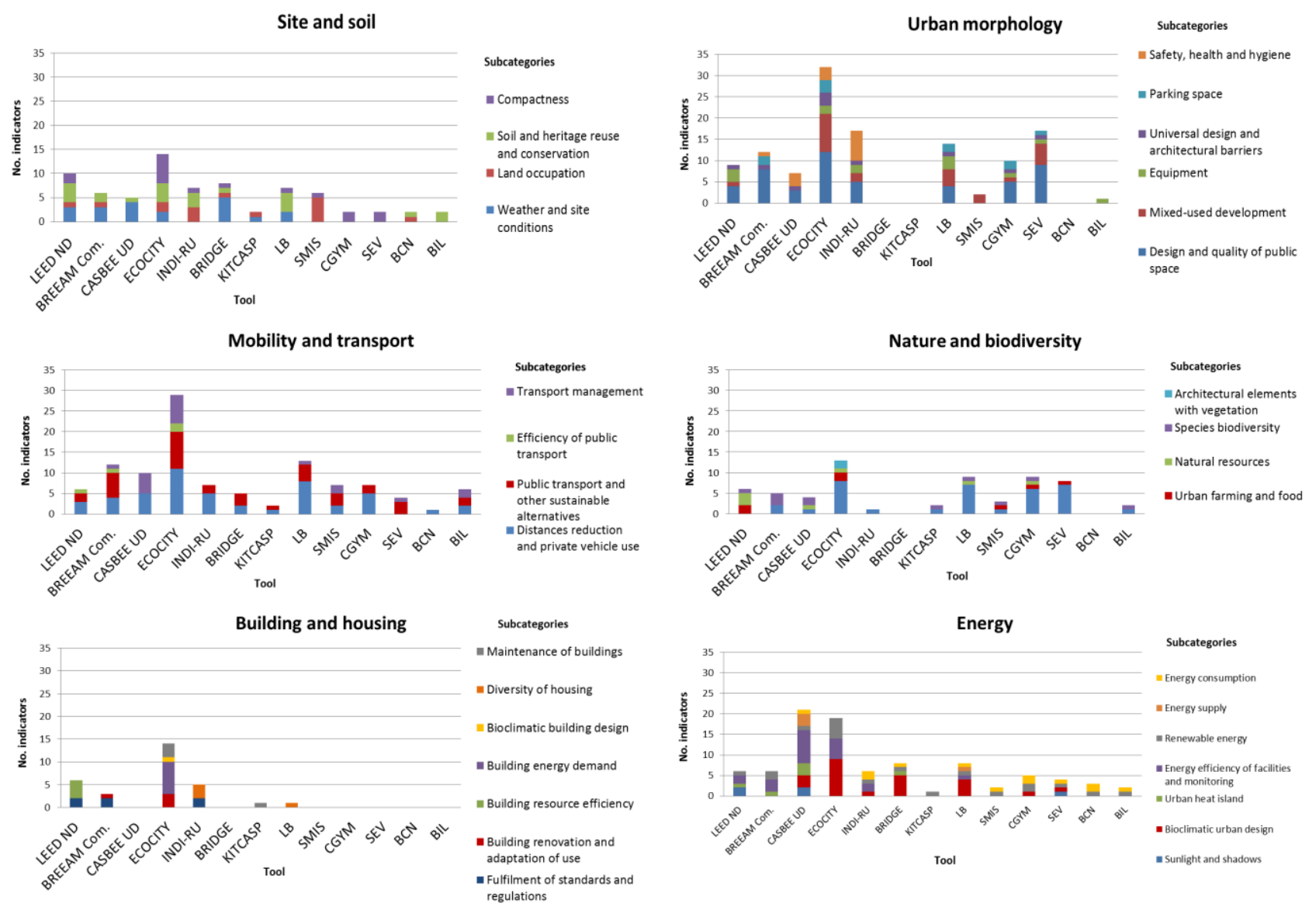

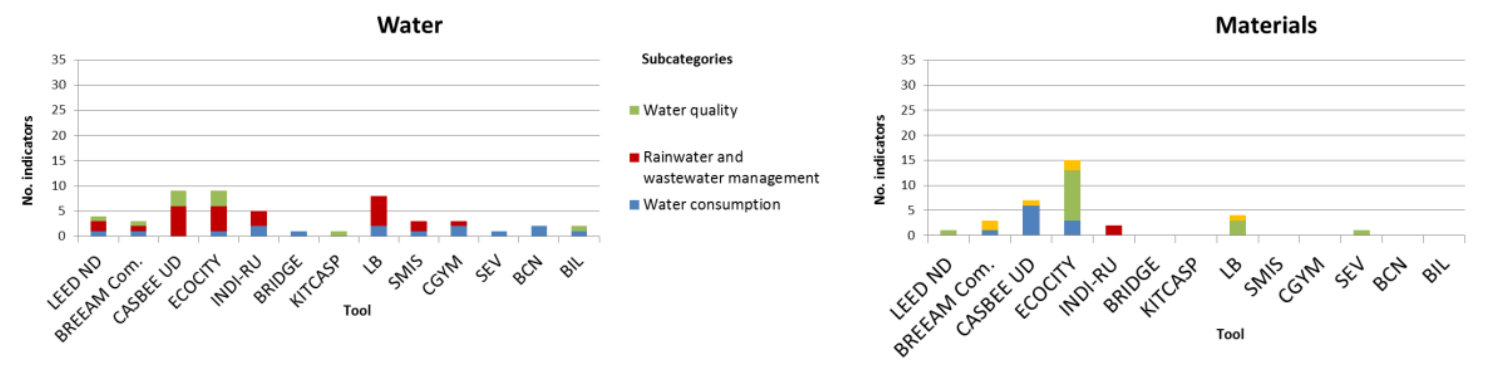

Subcategories

In Local materials

= Reused and recycled

Meused and recycled
materials materials - Certified reference materials - Low-impact materials
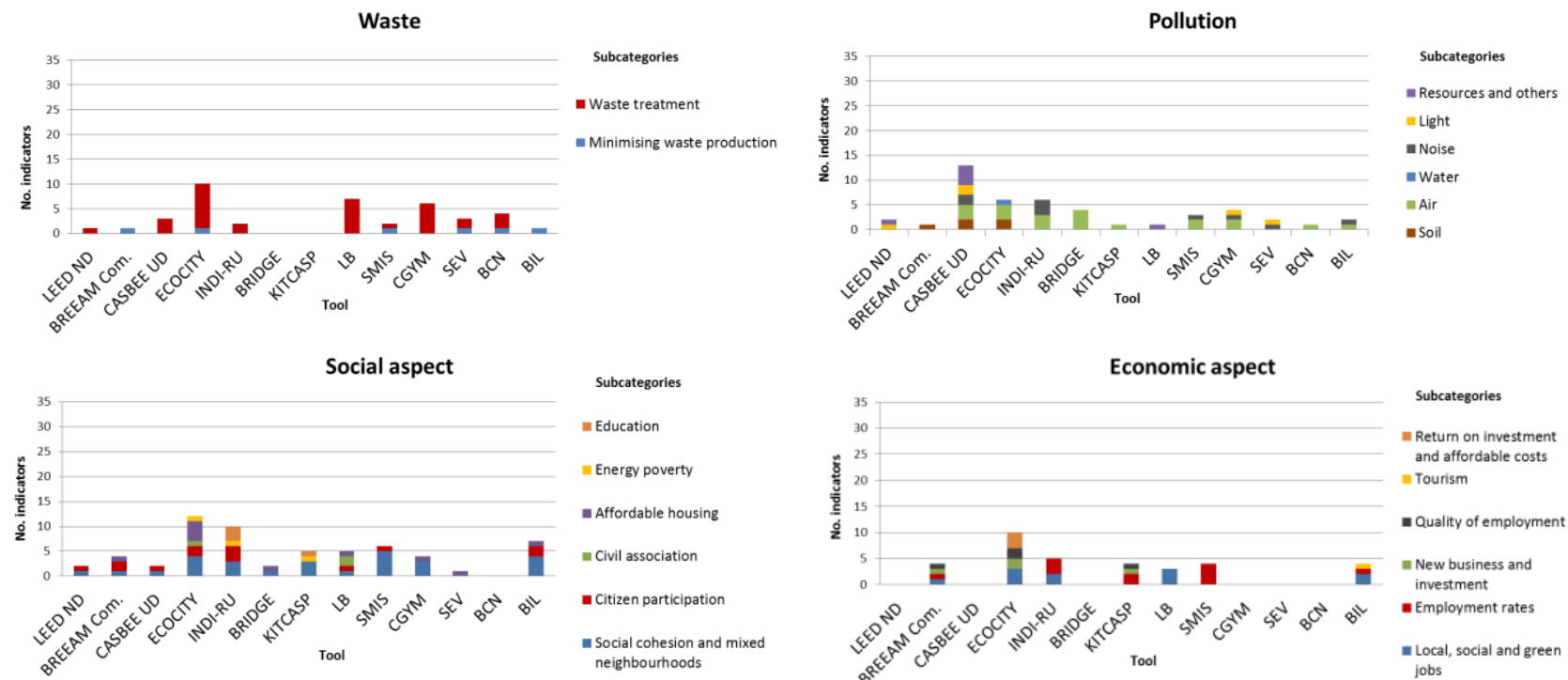

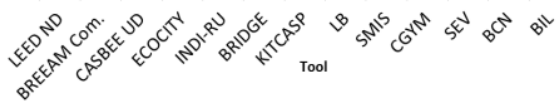

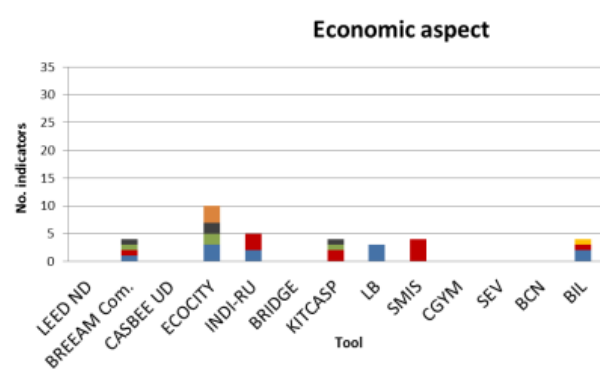

Subcategories

- Return on investmen and affordable costs " Tourism

- Quality of employment

- New business and investment - Employment rates Social cohesion and mixe

Subcategories

Managment and institution - Regulations to improve sustainability
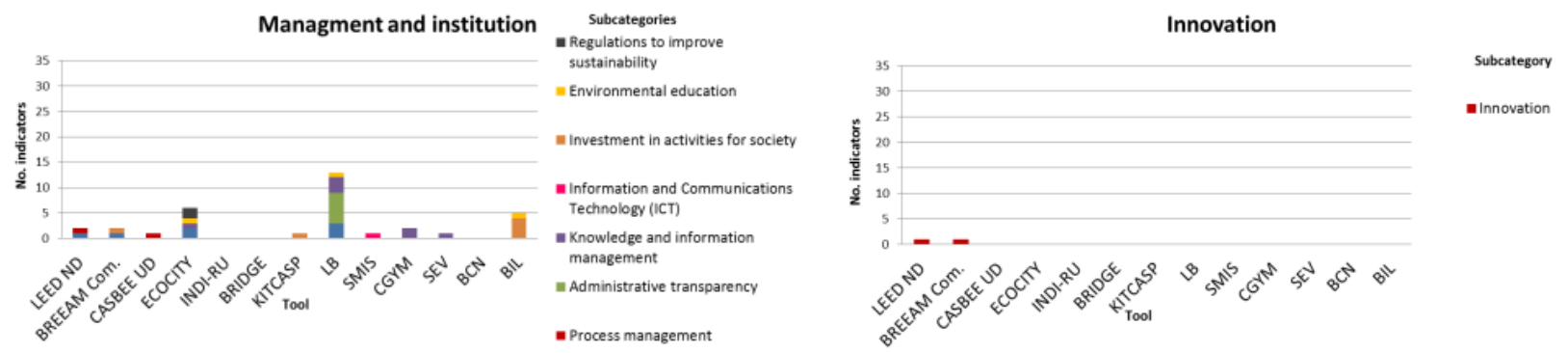

Figure 3. Number of indicators in each sub-category of the 13 selected tools 


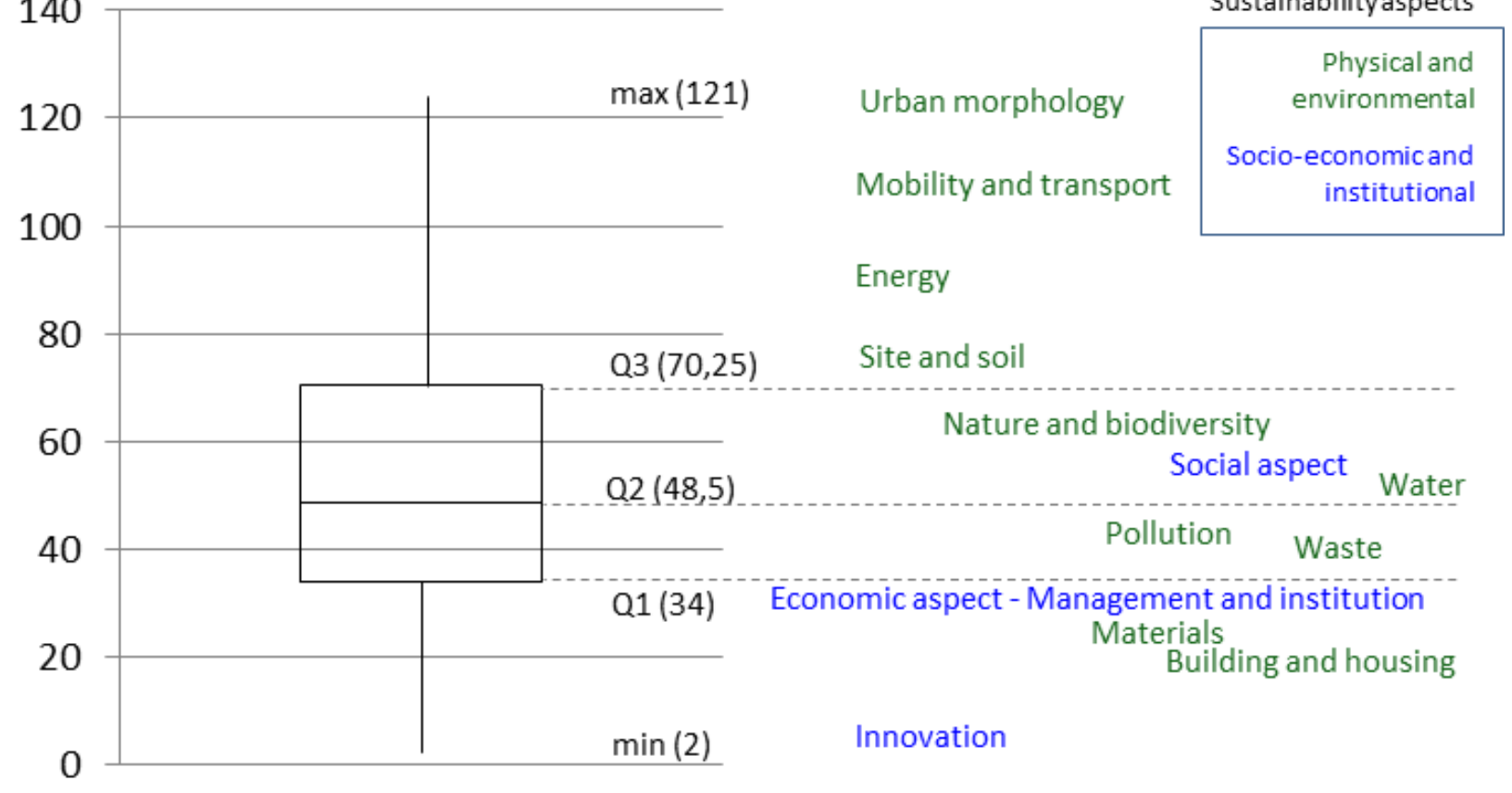

Figure 4. Statistical distribution of the number of indicators in the 14 categories

While Figure 2 represents the number of indicators that the 13 tools being studied include in the 14 categories, Figure 4 shows the statistical distribution of these data. The box plot diagram allows us to discover the most and least emphasised categories. The plotted results also evidence the balance of pillars of sustainability, which are the following, in order of coverage by tools: environmental, social, economic and institutional. In fact, the institutional aspect should be considered as the fourth pillar of sustainability, just as Sharifi and Murayama (2013) emphasised in their study. It is worth noting that it is treated as such in this work given the importance it deserves.

As seen in the box plot diagram in Figure 4, the categories of "urban morphology", "mobility and transport", "energy" and "site and soil" are the most highlighted by the tools since the number of indicators included in each one $(121,109,91$ and 73, respectively) are above the upper quartile $(70,25)$. Hence tools confer more importance to these three categories than to others. Indeed "urban morphology" is the category with more grouped indicators, thus it is more relevant than others.

Those categories in which the number of indicators is below and above the median $(48,5)$, within box length, represent $50 \%$ of the statistical data distribution. These are: "nature and biodiversity", "social aspect", "water", "pollution" and "waste". The number of indicators of these five categories falls between 40 and 62 , which is in the middle of the distribution.

The categories below the first quartile (34) represent the least emphasised ones in the tools, these being "economic aspect", "management and institution", "materials", "building and housing" and "innovation". These five categories bring together only a few indicators; e.g., "innovation" only has two.

Figure 3 provides an in-depth comparative analysis of the subcategories as it provides information about the number of indicators that the 13 tools confer to each subcategory. As estimated, the ECOCITY tool addresses the three most highlighted categories. Nonetheless, CASBEE is the tool that confers more indicators to "energy". It is noteworthy that "urban morphology" is also substantially reinforced by the SEV 
and INDI-RU tools, which consider urban design an essential aspect to achieve sustainability. However, BCN does not concede any indicator for this aspect.

The central subcategory identified in "urban morphology" is "design and quality of public space" as 8 of the 13 tools address it in depth. "Mixed-use" development is also a notable issue in this category. For "mobility and transport", all the tools, except SEV, make huge efforts to integrate "distances reduction and private vehicle use" to shorten commuting distances for inhabitants and to mitigate the impact of using private transport.

Differences among tools are less marked in "site and soil", where each tool has at least two indicators for this topic. Here it should be stated that a clear association is found between this aspect and "urban morphology". "Compactness" is the major issue in the "site and soil" category because it is present in eight of the tools, especially in European and Spanish ones, along with "mixed use", and "compactness" is a remarkable feature of Mediterranean cities.

"Nature and biodiversity" is considered mainly by ECOCITY, LB, CGYM and SEV, and the highlighted subcategory corresponds to the generation of green areas in neighbourhoods. Conservation of "species biodiversity" is also underlined by many tools, such as BREEAM Communities and CASBEE UD

Although the "social aspect" is considered by almost all the analysed tools, except BCN, it is worth noting that it is generally poorly treated, especially if we consider that it is one of the fundamental pillars of sustainability. In this category, "social cohesion and mixed neighbourhoods" is the key topic since 13 of the tools integrate several indicators to deal with it. "Affordable housing" is also an objective to achieve in social issues, which is targeted in seven tools. However, "energy poverty" is identified as a theme that requires further discussion because a larger number of European households are unable to access the socially and materially required level of energy services at home (Bouzarovski et al., 2011). Nevertheless, only ECOCITY, INDI-RU and KITCASP slightly consider it and no other tool covers this subcategory.

"Water" and "pollution" are considered in all 13 tools, but to a limit. For "water", the most notable subcategory is "rainwater and wastewater management", while six subcategories are distinguishable for "pollution", including pollution of "soil", "air", "water", "noise", "light" and resources", where "air" and "noise" are the most highlighted ones. In particular, BRIDGE is the tool that most stresses the "air" pollution subcategory as it integrates urban metabolism components into the impact assessment of planning interventions (González, 2013).

The "waste" category is also addressed by all the tools, especially by the "waste treatment" subcategory, whose accurate management is the objective, which is becoming more important (CEC, 2008).

Another somewhat forgotten area is the "economic aspect". LEED ND, CASBEE UD, BRIDGE, CGYM, SEV and $B C N$ do not contemplate this topic, and ECOCITY is the tool that best attempts to. The most targeted subcategory is "local, social and green jobs", which aims to promote the commercialisation of local products and employment in relation to environmental and social issues. As for the "social aspect", the "economic aspect" should be enhanced and encouraged to become a real consolidated pillar of sustainability.

"Materials" is a category that focuses on the implementation of low-impact, locally-produced materials, and of the recycled and reused products promotion. Materials of environmental quality signs are also rewarded in this category. Seven of the tools consider this aspect and the "reused and recycled materials" subcategory is the best extended one among all the tools. 
"Management and institution" comes over as a poorly managed issue because, despite it being considered by 10 of the tools, very few indicators are included in the proposed subcategories. However, this is a most important topic given the need to establish communication channels which enable administrative transparency. The LB tool, the best focused one, assigns a more prominent role to "administrative transparency", while BIL considers "investment in activities for society" to be a more important one. This category poses a challenging question for institutions to address their efforts to invest in the quality operation of cities. Indeed, as pointed out above, it should be considered to be the fourth pillar of sustainability.

Finally, "Building and housing" is poorly treated, possibly because it is usually considered in other kinds of tools, especially for design to assess the sustainability of a single building.

As reflected in Table 2, only three tools (LEED ND, BREEAM Communities and CASBEE UD) are quantitative and contemplate a rating score by categories and subcategories. Therefore, making an objective comparison of the weighting and importance assigned to each category is only possible with these three tools. The results are provided in Figure 5.
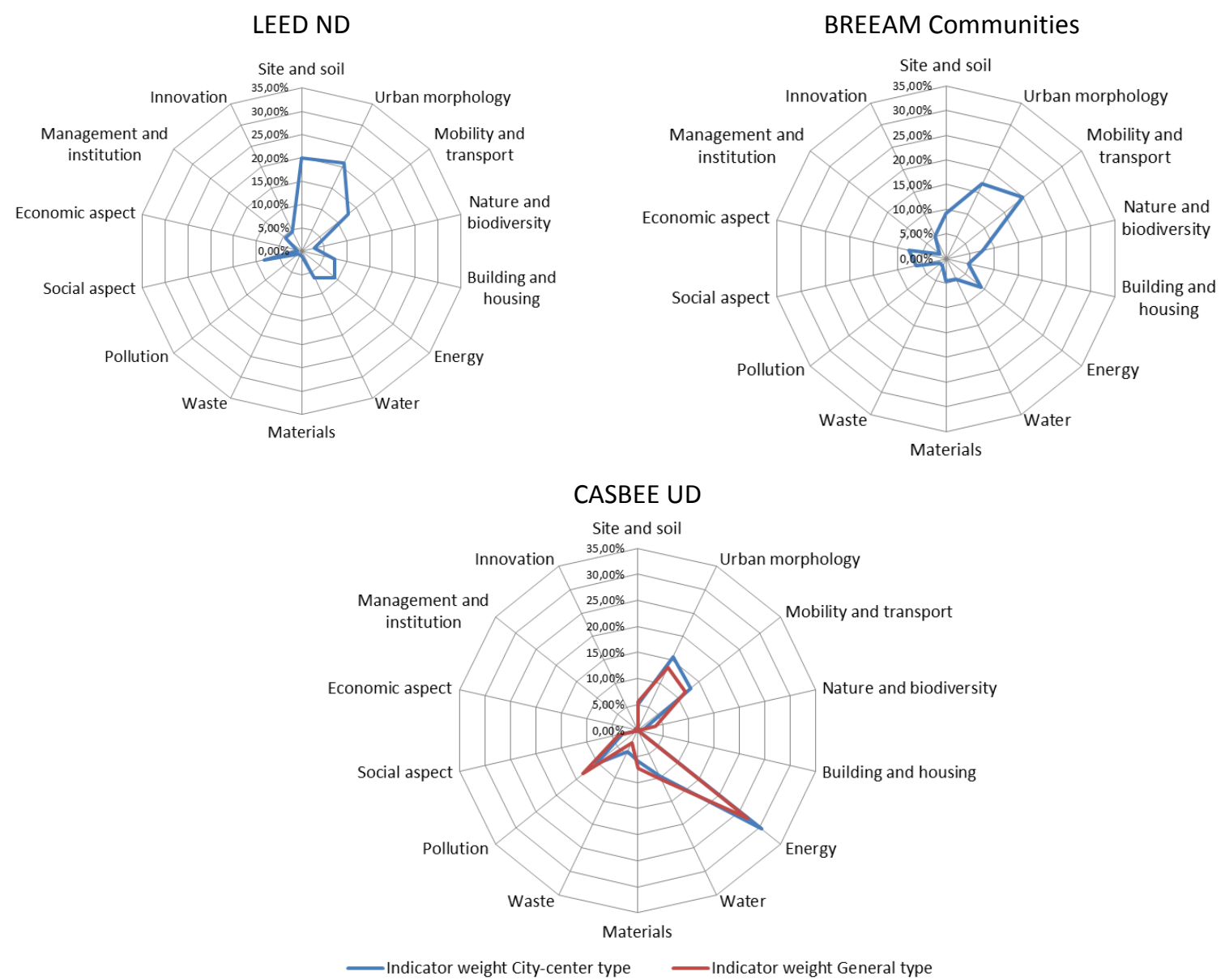

Figure 5. Percentage distribution of the weighting of categories in quantitative parametric tools

It is clear that the three tools place more importance on issues relating to environmental and physical aspects ("site and soil", "urban morphology", "mobility and transport", "nature and biodiversity", "buildings", "energy", "water", "materials", "waste" and "pollution"), and downplay the socio-economic and institutional aspects. Table 5 displays the percentage distribution numerically, where the LEED ND and 
BREEAM Communities grant about $80 \%$ of the weight to the former and only $20 \%$ to the latter. The difference for CASBEE UD is even wider as these percentages are approximately $95 \%$ and $5 \%$, respectively.

Table 5. Comparison of percentage distribution among the tools LEED ND, BREEAM Communities

\begin{tabular}{|c|c|c|c|c|c|c|c|}
\hline \multirow[t]{2}{*}{ Aspect } & \multirow[t]{2}{*}{ Category } & \multicolumn{2}{|l|}{ LEED ND } & \multicolumn{2}{|c|}{ BREEAM Communities } & \multicolumn{2}{|l|}{ CASBEE UD } \\
\hline & & $\%$ & Total \% & $\%$ & Total \% & $\%$ & Total \% \\
\hline \multirow{10}{*}{$\begin{array}{l}\text { Physical and } \\
\text { environmental } \\
\text { aspects }\end{array}$} & Site and soil & 20,00 & 81,82 & 9,18 & 79,59 & 5,50 & 94,90 \\
\hline & Urban morphology & 20,91 & & 16,84 & & 13,50 & \\
\hline & Mobility and transport & 12,73 & & 19,90 & & 11,75 & \\
\hline & Nature and biodiversity & 2,73 & & 7,65 & & 3,50 & \\
\hline & Building and housing & 7,27 & & 4,59 & & 0,00 & \\
\hline & Energy & 9,09 & & 9,18 & & 26,93 & \\
\hline & Water & 6,36 & & 4,59 & & 10,50 & \\
\hline & Materials & 0,91 & & 4,59 & & 7,23 & \\
\hline & Waste & 0,91 & & 1,53 & & 2,63 & \\
\hline & Pollution & 0,91 & & 1,53 & & 13,37 & \\
\hline \multirow{4}{*}{$\begin{array}{l}\text { Socio-economic and } \\
\text { institutional aspects }\end{array}$} & Social aspect & 8,18 & 18,18 & 6,12 & 20,41 & 4,15 & 5,10 \\
\hline & Economic aspect & 0,91 & & 7,65 & & 0,00 & \\
\hline & Management and institution & 4,55 & & 1,53 & & 0,95 & \\
\hline & Innovation & 4,55 & & 5,10 & & 0,00 & \\
\hline
\end{tabular}

\section{Discussion of urban sustainability indicators for the Spanish context}

Having analysed the 13 tools internationally and nationally, and classified the indicators, this section presents a discussion of the possible indicators to include in the proposed two-level structure, which was specifically built for the Spanish context. This structure involves those aspects that match the particular conditions of a region in terms of aspects such as climate, city urban form and socio-economic context, among others. The study also presents the objective or objectives to be achieved in each subcategory. Thus any included indicator should focus on fulfilling these specific objectives.

For each subcategory, at least one indicator has been suggested, which is intended to be intelligible and easy to apply. All 73 indicators presented in Table 6 are both qualitative and quantitative. For the quantitative ones, a set of mathematical expressions is provided to determine them. The qualitative indicators are advisory in nature and provide some sustainability trends to carry out good practices on the neighbourhood scale.

The indicators presented in this study involve all aspects of sustainability on the neighbourhood and city scales, and the objectives to be fulfilled have been taken from the review and analysis of 786 indicators from different tools with top-down applicability internationally and nationally. All 73 indicators proposed in Table 6 have already been previously tested and implemented in any region since they come from some of the reviewed tools. For this reason and because most of them can be obtained from data handled by municipalities and taken into account when designing or modifying urban plans or from public statistical databases, their implementability is guaranteed. Table 6 provides a formula that includes the way to calculate each indicator and a reference for those that have been taken from the literature review.

The proposed scheme can be implemented into other regions on the Mediterranean coast with similar characteristics regarding both urban planning and cultural issues. Even in Spain, cities could present 
significant differences across regions and specific factors, such as population, traditions or weather conditions, which affect the transferability of any resulting indicators set. Thus in order to meet the whole objective of each subcategory, other ad hoc indicators can be added to achieve the specific goals in a given region.

Table 6. The proposed indicators system structure to assess urban sustainability

\begin{tabular}{|c|c|c|c|c|}
\hline Category & Subcategory & Indicator and reference (if appropriate) & Type & Measurement Method \\
\hline \multirow[t]{5}{*}{ Site and soil } & $\begin{array}{l}\text { Weather and site } \\
\text { conditions }\end{array}$ & Consideration of weather conditions to design the city & Ql & $\begin{array}{l}\text { Designing according to climatic } \\
\text { zones in Spanish Building Code }\end{array}$ \\
\hline & Land occupation & Urbanised area of the municipality. SMIS (2010) & Qt & $\frac{\text { urban develeopment land }}{\text { total surf.of municipality }}=\%$ \\
\hline & Soil and heritage reuse & Percentage of abandoned buildings & Qt & $\%$ \\
\hline & and conservation & Percentage of land without use & & $\%$ \\
\hline & Compactness & Absolute compactness. SEV (2007) & Qt & $\frac{\text { cubic } V\left(m^{3}\right)}{\text { total urban } S\left(m^{2}\right)}=m$ \\
\hline \multirow[t]{8}{*}{$\begin{array}{l}\text { Urban } \\
\text { morphology }\end{array}$} & $\begin{array}{l}\text { Design and quality of } \\
\text { public space }\end{array}$ & Corrected compactness. SEV (2007) & Qt & $\frac{\text { cubic } V\left(m^{3}\right)}{\text { mitigating space }{ }^{1} S\left(m^{2}\right)}=m$ \\
\hline & Mixed-used & Proportion of residential buildings with integrated economic & Qt & No.of shops \\
\hline & development & activities & & $\overline{\text { No. of residentialbuildings }}$ \\
\hline & Equipment & Proportion of activities to meet daily needs in the neighbourhood & Qt & No.daily activities \\
\hline & & & & $\overline{\text { No.of total activities }}$ \\
\hline & $\begin{array}{l}\text { Universal design and } \\
\text { architectural barriers }\end{array}$ & Number of urban architectural barriers & Qt & No. architectural barriers \\
\hline & Parking space & Proportion of area designated for car parking on roads & Qt & $\frac{\text { Scar parking }\left(m^{2}\right)}{\text { Stotal }\left(m^{2}\right)}$ \\
\hline & $\begin{array}{l}\text { Safety, health and } \\
\text { hygiene }\end{array}$ & $\begin{array}{l}\text { Proportion of unhealthy housing (Charlot-Valdieu and Outrequin, } \\
\text { 2005) }\end{array}$ & Qt & $\frac{\text { No.of unhealthy households }}{\text { No.of total households }}$ \\
\hline \multirow[t]{5}{*}{$\begin{array}{l}\text { Mobility and } \\
\text { transport }\end{array}$} & $\begin{array}{l}\text { Distances, reduction } \\
\text { and private vehicle use }\end{array}$ & $\begin{array}{l}\text { Distance between home and daily activities (business, schools, health } \\
\text { centres) (IBEC, 2007) }\end{array}$ & Qt & $m$ \\
\hline & $\begin{array}{l}\text { Public transport and } \\
\text { other sustainable }\end{array}$ & $\begin{array}{l}\text { Distance to public transport from anywhere in the neighbourhood } \\
\text { Distance to public bicycle network from anywhere in the }\end{array}$ & Qt & $m$ \\
\hline & alternatives & neighbourhood & & $m$ \\
\hline & $\begin{array}{l}\text { Efficiency of public } \\
\text { transport }\end{array}$ & $\begin{array}{l}\text { Existence of alternative mobility (car sharing, etc.) (Gaffron et al., } \\
\text { 2008) }\end{array}$ & Ql & Yes/No \\
\hline & $\begin{array}{l}\text { Transport } \\
\text { management }\end{array}$ & $\begin{array}{l}\text { Citizen access to ICT information panels on public transport (Gaffron } \\
\text { et al., 2008) }\end{array}$ & Qt & $m$ \\
\hline \multirow[t]{5}{*}{$\begin{array}{l}\text { Nature and } \\
\text { biodiversity }\end{array}$} & Green areas & $\begin{array}{l}\text { Proportion of green spaces housing (Charlot-Valdieu and Outrequin, } \\
\text { 2005) }\end{array}$ & Qt & $\frac{\text { S green spaces }\left(m^{2}\right)}{\text { No.inhabi } \tan t s}=\frac{m^{2}}{\text { inhab. }}$ \\
\hline & $\begin{array}{l}\text { Urban farming and } \\
\text { food }\end{array}$ & $\begin{array}{l}\text { Proportion of area used for urban gardens in relation to the total } \\
\text { green surface }\end{array}$ & Qt & $\frac{\text { agricultural area }\left(\mathrm{m}^{2}\right)}{\text { green spacetotal } S\left(\mathrm{~m}^{2}\right)}$ \\
\hline & Natural resources & Existence of a conservation plan for natural resources & Ql & Yes/No \\
\hline & Species biodiversity & Proportion of autochthonous vegetation & Qt & $\frac{\text { autochthonous vegetation }\left(\mathrm{m}^{2}\right)}{\text { green spacetotal } S\left(\mathrm{~m}^{2}\right)}$ \\
\hline & $\begin{array}{l}\text { Architectural elements } \\
\text { with vegetation }\end{array}$ & Proportion of green roofs based on SEV (2007) & Qt & $\frac{\text { green roof } S\left(\mathrm{~m}^{2}\right)}{\text { roof total } S\left(\mathrm{~m}^{2}\right)}$ \\
\hline \multirow[t]{8}{*}{$\begin{array}{l}\text { Building and } \\
\text { housing }\end{array}$} & $\begin{array}{l}\text { Fulfilment of standards } \\
\text { and regulations }\end{array}$ & $\begin{array}{l}\text { Proportion of buildings certified by an environmental quality sign. } \\
\text { Based on (US GBC, 2009a, 2009b) }\end{array}$ & Qt & $\frac{\text { No.certified buildings }}{\text { No.of total buildings }}$ \\
\hline & Building renovation & Proportion of abandoned or unused buildings that have been & Qt & No.renovated buildings \\
\hline & and adaptation of use & renovated. & & No.abandoned / unused buildings \\
\hline & $\begin{array}{l}\text { Building resource } \\
\text { efficiency }\end{array}$ & $\begin{array}{l}\text { Water consumption per occupant } \\
\text { Electricity consumption per occupant }\end{array}$ & Qt & $\begin{array}{l}\text { litre / person } \\
K W h / m^{2} \cdot \text { year.person }\end{array}$ \\
\hline & $\begin{array}{l}\text { Building energy } \\
\text { demand }\end{array}$ & $\begin{array}{l}\text { Proportion of buildings with insulation in the thermal envelope } \\
\text { based on (Gaffron et al., 2008) }\end{array}$ & Qt & $\frac{\text { No.insulated buildings }}{\text { No.total buildings }}$ \\
\hline & $\begin{array}{l}\text { Bioclimatic building } \\
\text { design }\end{array}$ & Consideration of the solar orientation in the building design & Ql & Yes/No \\
\hline & Diversity of housing & Balanced ratio of different types of housing & Qt & $\%$ \\
\hline & $\begin{array}{l}\text { Maintenance of } \\
\text { buildings }\end{array}$ & $\begin{array}{l}\text { Minimise maintenance and operating costs by selecting appropriate } \\
\text { materials and HVAC systems and building services (Gaffron et al., } \\
\text { 2008) }\end{array}$ & Ql & Yes/No \\
\hline \multirow[t]{4}{*}{ Energy } & Sunlight and shade & Tree incorporation to mitigate the effect of sun during summer & Qt & No.trees \\
\hline & & periods. SEV (2007) & & $\overline{S \text { public spaces }\left(\mathrm{m}^{2}\right)}$ \\
\hline & $\begin{array}{l}\text { Bioclimatic urban } \\
\text { design }\end{array}$ & Consideration of ventilation flows for urban design & Ql & Yes/No \\
\hline & Urban heat island & $\begin{array}{l}\text { Proportion of green space and water surfaces in the area to reduce } \\
\text { the rise in surface temperature. Based on CASBEE UD (IBEC, 2007) }\end{array}$ & Qt & $\frac{\text { Green \& water area }\left(m^{2}\right)}{\text { public space }\left(m^{2}\right)}$ \\
\hline
\end{tabular}




\begin{tabular}{|c|c|c|c|c|}
\hline & $\begin{array}{l}\text { Energy efficiency of } \\
\text { facilities and } \\
\text { monitoring }\end{array}$ & $\begin{array}{l}\text { Proportion of buildings whose energy rating is higher than average } \\
(A, B, C)\end{array}$ & Qt & $\frac{\text { No.buildings } A B C}{\text { No.totalbuildings }}$ \\
\hline & Renewable energy & Proportion of self-sufficiency with renewable energy. SMIS (2010) & Qt & $\frac{\text { Userenewable energy }}{U \text { Useconientionalenerav }}$ \\
\hline & Energy supply & $\begin{array}{l}\text { Proportion of local energy production in the district based on LB } \\
\text { (2010) }\end{array}$ & Qt & $\frac{\text { local energy produced }}{\text { consumedenergy }}$ \\
\hline & Energy consumption & Energy consumption per sector based on CGYM (2010) & Qt & $k W h \cdot y e a r / s e c t o r$ \\
\hline \multirow[t]{5}{*}{ Water } & Water consumption & Proportion of public buildings using water saving (WST) techniques. & Qt & No.buildings with WST \\
\hline & & Charlot-Valdieu and Outrequin (2005) & & $\overline{\text { No.total public buildings }}$ \\
\hline & Rainwater and & Proportion of storm water reused & Qt & litres of stormwater reused \\
\hline & $\begin{array}{l}\text { wastewater } \\
\text { management }\end{array}$ & & & litres of stormwater collected \\
\hline & Water quality & $\begin{array}{l}\text { Using a water purification treatment system employing natural } \\
\text { purification mechanisms (i.e. stimulating microorganisms). Based on } \\
\text { CASBEE UD (IBEC, 2007) }\end{array}$ & Ql & Yes/No \\
\hline \multirow[t]{6}{*}{ Materials } & Low-impact materials & Carry out inventory of materials used in public works & QI & -Yes/No \\
\hline & $\begin{array}{l}\text { Certified reference } \\
\text { materials }\end{array}$ & $\begin{array}{l}\text { Proportion of use of materials with environmental certification for } \\
\text { public works }\end{array}$ & Qt & $\frac{\text { No.certified materials }}{\text { No.total materials used }}$ \\
\hline & Reused and recycled & Proportion of reused or recycled materials in public works & Qt & No.recycled materials \\
\hline & materials & & & No.total materials used \\
\hline & Local materials & Proportion of local materials used in public works & Qt & No.local materials \\
\hline & & & & $\overline{\text { No.total materials used }}$ \\
\hline \multirow[t]{2}{*}{ Waste } & $\begin{array}{l}\text { Minimising waste } \\
\text { production }\end{array}$ & $\begin{array}{l}\text { Proportion of construction and demolition waste (CDW) treated by } \\
\text { an authorised waste manager }\end{array}$ & Qt & $\frac{T C D W \text { well }- \text { treated }}{T C D W \text { produced }}$ \\
\hline & Waste treatment & Distance from housing to selective garbage containers & Qt & $m$ \\
\hline \multirow[t]{6}{*}{ Pollution } & Soil & Level of soil contamination & Qt & Mg/litre \\
\hline & Air & $\begin{array}{l}\text { Proportion of population exposed to pollution of } \mathrm{NO}_{2} \text { above } 50 \\
\mathrm{ug} / \mathrm{m}^{3} \text { average annual hourly. Charlot-Valdieu and Outrequin (2005) }\end{array}$ & Qt & $\frac{\text { No.inhab.exp osed }}{\text { No.inhab.total }}$ \\
\hline & Water & Level of heavy metals in the water & & Mg/litre \\
\hline & Noise & $\begin{array}{l}\text { Proportion of population exposed to noise ratio } \geq 65 \mathrm{~dB}(\mathrm{~A}) \text {. Based } \\
\text { on housing. Charlot-Valdieu and Outrequin (2005) }\end{array}$ & Qt & $\frac{\text { No.inhab.exp osed }}{\text { No.inhab.total }}$ \\
\hline & Light & $\begin{array}{l}100 \% \text { Provision of luminaire street lamps without light pollution } \\
\text { based on SEV (2007) }\end{array}$ & Qt & $\%$ \\
\hline & Resources and others & Distance of neighbourhoods to industrial areas & Qt & $m$ \\
\hline \multirow[t]{10}{*}{ Social aspect } & Social cohesion and & Proportion of population with low income & Qt & Lowincome population \\
\hline & mixed neighbourhoods & & & Total population \\
\hline & Citizen participation & Proportion of adopted consultation with citizens & Qt & No.consultations \\
\hline & & & & $\overline{\text { No.adopted decisions }}$ \\
\hline & Civil association & Proportion of spaces where citizens can co-exist & Qt & No.meeting spaces \\
\hline & & & & No.public spaces \\
\hline & Affordable housing & Proportion of social housing in the neighbourhood. CGYM (2010) & Qt & No.social houses \\
\hline & & & & No.houses \\
\hline & Energy poverty & Proportion between energy expenditure and household income & Qt & $\frac{\text { Energy exp enditure }}{\text { Householdincome }}$ \\
\hline & Education & Percentage of truancy & Qt & $\%$ \\
\hline \multirow[t]{6}{*}{$\begin{array}{l}\text { Economic } \\
\text { aspect }\end{array}$} & $\begin{array}{l}\text { Local, social and green } \\
\text { jobs }\end{array}$ & $\begin{array}{l}\text { Proportion of economic activities dedicated to green jobs in the } \\
\text { neighbourhood (waste management, local products, etc.) }\end{array}$ & Qt & $\frac{\text { No. green jobs }}{\text { No.economic activities }}$ \\
\hline & Employment rates & Unemployment rate in the district & Qt & $\%$ \\
\hline & $\begin{array}{l}\text { New business and } \\
\text { investment }\end{array}$ & $\begin{array}{l}\text { Proportion of new businesses financially supported based on Gaffron } \\
\text { et al. (2008) }\end{array}$ & Qt & $\frac{\text { No. financiated businesses }}{\text { No.businesses }}$ \\
\hline & Quality of employment & Level of qualifications & Qt & $\begin{array}{l}\text { \% people with Primary studies; } \\
\text { \% Secondary; \% University } \\
\text { Degree }\end{array}$ \\
\hline & Tourism & Tourist vitality in the neighbourhood & Qt & n. of visitors \\
\hline & $\begin{array}{l}\text { Return on investment } \\
\text { and affordable costs }\end{array}$ & Feasibility of investment & Qt & TIR \\
\hline \multirow{8}{*}{$\begin{array}{l}\text { Managemen } \\
\text { t and } \\
\text { institution }\end{array}$} & $\begin{array}{l}\text { Institutional } \\
\text { management }\end{array}$ & Cooperation among administrations & Qt & No. of workshops held \\
\hline & Process management & $\begin{array}{l}\text { Proportion of companies and institutions with an implemented } \\
\text { management system. Based on IBEC (2007) }\end{array}$ & Qt & $\frac{\text { No.well - managed companies }}{\text { No.companies }}$ \\
\hline & $\begin{array}{l}\text { Administrative } \\
\text { transparency }\end{array}$ & Integrating Agenda 21 into urban planning & Ql & Yes/No \\
\hline & $\begin{array}{l}\text { Knowledge and } \\
\text { information } \\
\text { management }\end{array}$ & $\begin{array}{l}\text { Development of information material with official data and technical } \\
\text { reports }\end{array}$ & Qt & No. of campaigns \\
\hline & ICT & Citizens' access to Information and Communications Technology (ICT) & Qt & $\%$ dwellings with Internet access \\
\hline & $\begin{array}{l}\text { Investment in activities } \\
\text { for society }\end{array}$ & Proportion of public expenditure relating to activities for society & Qt & $\frac{\text { Public exp enditure for society }}{\text { Total public exp enditure }}$ \\
\hline & $\begin{array}{l}\text { Environmental } \\
\text { education }\end{array}$ & Development of information material on environmental matters & Qt & No. of campaigns \\
\hline & $\begin{array}{l}\text { Regulations to improve } \\
\text { sustainability }\end{array}$ & $\begin{array}{l}\text { Incorporating public parking rates into city centres } \\
\text { Incorporation of discounts and bonuses to use public transport }\end{array}$ & Qt & $\%$ users of public transport \\
\hline
\end{tabular}


Mitigating public space is one that ensures the interrelationship of people and the relationship of the subject with nature (green and living spaces) SEV (2007)

[QI]: Qualitative indicator; [Qt]: Quantitative indicator; [S]: Surface; [V]: Volume; [N]: Number; [T]: Tone

\section{Conclusions}

This paper presents a comprehensive analysis of the 13 tools used to assess urban sustainability internationally and nationally to approach the Spanish case study. The results of the analysis indicate a huge difference among the approaches that each tool uses to meet its goal. Although almost all the tools cover the majority of the categories proposed in the study, they all focus closely on physical and environmental issues, and generally overlook social, economic and institutional ones.

Based on the review done of the state-of-the-art literature, a classification of the indicators in the tools was made. The most and least stressed topics were identified by means of a comparative analysis of the number of indicators included, and of the tools that target each topic found. A new urban sustainability indicators structure based on a two-level scheme is provided, which consists in a set of 14 major categories that must be covered to achieve urban sustainability, and a set of 69 subcategories that go into categories in more detail. Within this structure, at least one indicator per subcategory is suggested. The proposed structure generates a comprehensive scheme to cover all the aspects that must be considered in any indicators system to assess urban sustainability on the Mediterranean coast.

In fact the sustainability concept varies from region to region. Hence a context-specific set of indicators integrated into the proposed scheme should be provided to address the characteristics of the region. Not all aspects are necessarily covered in all regions and for all tools because the specific conditions of each region may have various requirements, thus the approach of indicators. For example, while LEED ND covers specific aspects of the dispersed city, and BREEAM Communities and CASBEE UD do not refer to compact urban development, this disperse model is inconceivable in Mediterranean countries where the urban structure is usually compact. The tools discussed at European and Spanish levels provide guidelines to promote compact cities. It is obvious that the operation of the city varies vastly depending on its urban layout.

Consequently sustainability is deeply rooted in the urban form in not only physical and environmental issues, but also socio-economic and institutional aspects. Thus "urban morphology" conditions such diverse aspects as: "site and soil" for urban compactness and efficient land use; "mobility and transport" for the distances commuted by the population; "nature and biodiversity" given the possibility of integrating green areas into the city; "building and housing", since it determines the shape and type of buildings, and therefore their energy performance; "energy" because the urban form enables the possibility of sunlight and shade, and the use of natural conditioning strategies for urban spaces and buildings; the "social aspect" due to short distances that bring inhabitants and their relationships together; the "economic aspect" given the revival of commercial activities in the neighbourhood; and "management and institution" as a result of transparent decision making. Therefore, the "site and soil" and "urban morphology" categories are those that are best rooted in others, and are strongly related to most, which conditions their development.

As the features of Mediterranean countries are similar in terms of environment, culture and socioeconomic aspects, the proposed structure can be extrapolated to other countries in the same geographical area with similarities. Therefore, this system enables most of the indicators suggested herein to be applied to other countries. The structure can also be extended with more indicators, which attempt to further 
detail each specific objective of the subcategories in order to provide a flexible, living tool that offers the opportunity to continuously adapt to the complex system involving the city.

The structure of indicators herein proposed is a useful tool for the decision-making process to help the different stakeholders involved in urban projects: developers, urban planners, architects and professionals in the construction sector, officers of public administrations, politicians, and civic associations. The system will assess and provide indications on sustainability patterns for both new urban developments and regeneration projects in existing neighbourhoods, which will lead the way towards sustainability.

\section{Supplementary Information}

Supplementary Information 1: List of existing indicators included in the 13 analysed tools.

Supplementary Information 1 includes the detailed description of the indicators considered in all the 13 analysed tools.

Supplementary Information 2: Classification of the indicators into the 14 categories and 69 subcategories

Supplementary Information 2 includes the classification of the indicators contained in the 13 analysed tools according to the common proposed structure.

\section{References}

BCN. Sistema de Indicadores Municipales de la Diputación de Barcelona (Municipal Indicators System for Barcelona Provincial Council); 2009. URL: http://www.diba.cat/documents/63810/508804/xarxasostpdf-memoriaindicadors08-pdf.pdf (last access, October 2014)

BIL. Indicadores de Sostenibilidad de Bilbao (Sustainability Indicators for Bilbao); 2008. URL: http://www.bilbao.net/agenda21/pdf/indicadores2008.pdf (last access, October 2014).

Blum A. HQE2R-research and demonstration for assessing sustainable neighborhood development. In: Deakin M, Mitchell G, Nijkamp P, Vreeker R, editors. Sustain urban Dev Vol 2 Environ Assess methods. New York; 2007. p. 412-28.

Bourdic L, Salat S. Building energy models and assessment systems at the district and city scales: a review. Build Res Inf 2012; 40(4):518-26.

Bourdic L, Salat S, Nowacki C. Assessing cities: a new system of cross-scale spatial indicators. Build Res Inf 2012; 40(5):592-605.

Bouzarovski S, Sarlamanov R, Petrova S. The Governance of Energy Poverty in Southeastern Europe. 2011.

BRE Global. SD5065 technical guidance manual: version 1. BREEAM for Communities assessor manual: development planning application stage. 2011.

BRE Global. BREEAM URL: http://www.breeam.org/page.jsp?id=346 (last access, April 2014)

Brundtland GH. Our Common Future. United Nations World Commission on Environment and Development. Oslo; 1987.

Bulkeley H. Cities and the Governing of Climate Change. Annu Rev Environ Resour 2010; 35(1):229-53. 
Byrd, Ho. Transport energy and city density: A case study of how renewable energy can reverse the curve. 6th Australas Hous Res Conf. Adelaide; 2012.

Castán V, Bulkeley H. A survey of urban climate change experiments in 100 cities. Glob Environ Change 2013; 23(1):92-102

Castanheira G, Bragança L. The evolution of the sustainability assessment tool SBTooIPT: from buildings to the built environment. ScientificWorldJournal 2014; (2356-6140), 62 (4), p. 1.

CEC. Directive $2008 / 98 / C E$, of $19^{\text {th }}$ Novembe, on waste and repealing certain Directives. Off J Eur Union 2008: L 312/3 [22.11.2008].

CGYM. Sistema de Indicadores y Condicionantes para Ciudades Grandes y Medianas (Indicators and Constraints System for Large and Medium Cities); 2010. URL: http://www.magrama.gob.es/es/calidady-evaluacion-ambiental/temas/medio-ambiente-

urbano/indicadores_ciudades_grandes_y_medianas_tcm7-177731.pdf (last access, October 2014).

Charlot-Valdieu C, Outrequin P. Des indicateurs de developpement Durable pour l'evaluation des Projets de renouvellement urbain: Le modele INDI - RU 2005.

Chrysoulakis N, Lopes M, San José R, Grimmond CSB, Jones MB, Magliulo V, Klostermann JE, Synnefa A, Mitraka Z, Castro EA, González A, RVogt, Spano D, Pigeon G, Freer-Smith P, Staszewski T, Hodges N, Mills $\mathrm{G}$, Cartalis $\mathrm{C}$. Sustainable urban metabolism as a link between bio-physical sciences and urban planning: The BRIDGE project. Landsc Urban Plan 2013; 112:100-117

Daly G, González A. Key Indicators for Territorial Cohesion and Spatial Planning: The Reform of the EU Cohesion Policy and the New Role of Spatial Indicators. Borderlands: The Journal of Spatial Planning in Ireland. 2013; 3: 77-89.

Daly G, González A, Gleeson J, McCarthy E, Adams N, Pinch P, Burns MC, Johannesson H, Sigurbjarnarson V, Valtenbergs V, Livina A, et al. KITCASP Key Indicators for Territorial Cohesion and Spatial Planning. Final Report. Part B. ESPON and National University of Ireland, Maynooth; 2013.

Dizdaroglu D, Yigitcanlar T. A parcel-scale assessment tool to measure sustainability through urban ecosystem components: The MUSIX model. Ecol Indic 2014; 41:115-30.

EarthCraft. Homepage of EarthCraft. 2014. URL: http://earthcraft.org/communities (last access, March 2014)

Gaffron P, Huismans G, Skala F. Ecocity book I: a beter place to live. Vienna; 2005.

Gaffron P, Huismans G, Skala F. Ecocity book II: how to make it happen. Vienna; 2008.

Gil J, Duarte JP. Tools for evaluating the sustainability of urban design: a review. Proc ICE - Urban Des Plan 2013; 166(6):311-25.

Ghosh S, Vale R. Typologies and Basic Descriptors of New Zealand Residential Urban Forms. J Urban Des 2009; 14(4):507-36.

González A, Donnelly A, Jones M, Chrysoulakis N and Lopes M. A Decision-Support System for Sustainable Urban Metabolism in Europe. Environ Impact Assess Rev 2013; 38: 109-119. 
Haapio A, Viitaniemi P. A critical review of building environmental assessment tools. Environ Impact Assess Rev 2008; 28(7):469-82.

Haapio A. Towards sustainable urban communities. Environ Impact Assess Rev 2012; 32(1):165-9.

Huedo P, López-Mesa B. Revisión de herramientas de asistencia en la selección de soluciones constructivas sostenibles de edificación. Inf la Construcción 2013; 65(529):77-88.

IBEC. CASBEE for Urban Development. Technical manual 2007 edition.

LB. Libro Blanco Planeamiento Urbano Sostenible (Spanish White Paper on Sustainable Urban Planning); 2010.

URL: http://www.fomento.gob.es/MFOM/LANG_CASTELLANO/DIRECCIONES_GENERALES/ARQ_VIVIENDA/ SUELO_Y_POLITICAS/ESTUDIOS/Libro_blanco/EI_Libro_Blanco.htm (last access, October 2014).

Luederitz C, Lang DJ, Von Wehrden H. A systematic review of guiding principles for sustainable urban neighborhood development. Landsc Urban Plan 2013; 118:40-52.

Macías M, García Navarro J. Metodología y herramienta VERDE para la evaluación de la sostenibilidad en edificios. Inf la Construcción 2010; 62(517):87-100.

Makido Y, Dhakal S, Yamagata Y. Relationship between urban form and $\mathrm{CO} 2$ emissions: Evidence from fifty Japanese cities. Urban Clim 2012; 2:55-67.

Nguyen BK, Altan H. Comparative Review of Five Sustainable Rating Systems. Procedia Eng 2011; 21(0):37686.

OECD. Organisation for Economic Co-operation and Development webpage. 2014. URL: http://www.oecd.org (last access, September 2014)

Okeil A. A holistic approach to energy efficient building forms. Energy Build 2010 Sep; 42(9):1437-44.

Pickett STA, McGrath B, Cadenasso ML, Felson AJ. Ecological resilience and resilient cities. Build Res Inf 2014; 42(2):143-57.

Rueda S. Barcelona, ciudad mediterránea, compacta y compleja. Una visión de futuro más sostenible. Ayuntamiento de Barcelona; 2007.

Rueda S, Cuchí A, Subirats J, de Mingo M, Díaz A. Libro Verde de Medio Ambiente Urbano. Madrid: Ministerio de Medio Ambiente; 2007.

SEV. Plan Especial de Indicadores de Sostenibilidad Ambiental de la Actividad Urbanística de Sevilla (Special Plan for Environmental Sustainability Indicators for the Urban Development in Seville); 2007. URL: http://www.sevilla.org/urbanismo/plan_indicadores/Index.html (last access, October 2014).

SCR. Homepage of sustainable community rating. 2014. URL: http://www.places.vic.gov.au/?c=VPage\&cid=1192185989323\&pagename=Sustainability\%2FLayout (last access, September 2014)

Sharifi A, Murayama A. A critical review of seven selected neighborhood sustainability assessment tools. Environ Impact Assess Rev 2013; 38:73-87. 
Sharifi A, Murayama A. Neighborhood sustainability assessment in action: Cross-evaluation of three assessment systems and their cases from the US, the UK, and Japan. Build Environ 2014; 72:243-58.

SMIS. Sistema Municipal de Indicadores de Sostenibilidad (Municipal Sustainability Indicator System); 2010 URL: http://www.fomento.gob.es/NR/rdonlyres/82B973EA-5970-46F0-8AE665370D40A1F5/111505/SIST_MUNI_INDI_SOSTE_tcm7177732.pdf (last access, October 2014).

United Nations. Agenda 21. 1995. URL: http://web.archive.org/web/20090420073232/http://www.un.org/esa/sustdev/documents/agenda2 1/spanish/agenda21sptoc.htm (last access, October 2014)

UN-Habitat. Global Report on Human Settlements 2011. Cities and Climate Change. London; 2011.

UN Sustainable Development. Indicators of sustainable development: Guidelines and methodologies. 1998.

US GBC. LEED for neighborhood development. The U.S. Green Building Council, 2009.

US GBC. LEED. 2009. URL: http://www.usgbc.org/leed\#rating (last access, May 2014)

Wilson B. Urban form and residential electricity consumption: Evidence from Illinois, USA. Landsc Urban Plan 2013; 115:62-71

Zhao J, Xiao L, Tang L, Shi L, Su X, Wang H, Song Y, Shao, G. Effects of spatial form on urban commute for major cities in China. Int J Sustain Dev World Ecol 2014; 21 (4): 361. 
Supplementary Information 1: List of existing indicators included in the 11 tools analysed.

Supplementary Information 1 includes the detailed description of the indicators considered in all the 11 tools analysed.

Table S1.1 LEED ND

\begin{tabular}{|c|c|}
\hline \multirow[t]{2}{*}{ Code } & \multirow{2}{*}{$\begin{array}{l}\text { Categories / Indicators } \\
\text { SMART LOCATION AND LINKAGE }\end{array}$} \\
\hline & \\
\hline LEED.1 & Smart Location \\
\hline LEED. 2 & Imperilled Species and Ecological Communities \\
\hline LEED.3 & Wetland and Water Body Conservation \\
\hline LEED.4 & Agricultural Land Conservation \\
\hline LEED.5 & Floodplain Avoidance \\
\hline LEED.6 & Preferred Locations \\
\hline LEED.7 & Brownfield Redevelopment \\
\hline LEED. 8 & Locations with Reduced Automobile Dependence \\
\hline LEED.9 & Bicycle Network and Storage \\
\hline LEED.10 & Housing and Jobs Proximity \\
\hline LEED.11 & Steep Slope Protection \\
\hline LEED.12 & Site Design for Habitat or Wetland and Water Body Conservation \\
\hline LEED.13 & Restoration of Habitat or Wetlands and Water Bodies \\
\hline \multirow[t]{2}{*}{ LEED.14 } & Long-Term Conservation Management of Habitat or Wetlands and Water Bodies \\
\hline & NEIGHBORHOOD PATTERN AND DESIGN \\
\hline LEED.15 & Walkable Streets \\
\hline LEED.16 & Compact Development \\
\hline LEED.17 & Connected and Open Community \\
\hline LEED.18 & Walkable Streets \\
\hline LEED.19 & Compact Development \\
\hline LEED. 20 & Mixed-Use Neighbourhood Centres \\
\hline LEED. 21 & Mixed-Income Diverse Communities \\
\hline LEED. 22 & Reduced Parking Footprint \\
\hline LEED.23 & Street Network \\
\hline LEED.24 & Transit Facilities \\
\hline LEED. 25 & Transportation Demand Management \\
\hline LEED.26 & Access to Civic and Public Spaces \\
\hline LEED. 27 & Access to Recreation Facilities \\
\hline LEED. 28 & Visitability and Universal Design \\
\hline LEED.29 & Community Outreach and Involvement \\
\hline LEED.30 & Local Food Production \\
\hline LEED.31 & Tree-Lined and Shaded Streets \\
\hline \multirow[t]{2}{*}{ LEED.32 } & Neighbourhood Schools \\
\hline & GREEN INFRASTRUCTURE AND BUILDINGS \\
\hline LEED.33 & Certified Green Building \\
\hline LEED.34 & Minimum Building Energy Efficiency \\
\hline LEED.35 & Minimum Building Water Efficiency \\
\hline LEED.36 & Construction Activity Pollution Prevention \\
\hline LEED.37 & Certified Green Buildings \\
\hline LEED.38 & Building Energy Efficiency \\
\hline LEED.39 & Building Water Efficiency \\
\hline LEED.40 & Water-Efficient Landscaping \\
\hline LEED.41 & Existing Building Reuse \\
\hline LEED.42 & Historic Resource Preservation and Adaptive Use \\
\hline LEED.43 & Minimized Site Disturbance in Design and Construction \\
\hline LEED.44 & Stormwater Management \\
\hline LEED.45 & Heat Island Reduction \\
\hline LEED.46 & Solar Orientation \\
\hline LEED.47 & On-Site Renewable Energy Sources \\
\hline LEED.48 & District Heating and Cooling \\
\hline
\end{tabular}




\begin{tabular}{ll} 
LEED.49 & Infrastructure Energy Efficiency \\
LEED.50 & Wastewater Management \\
LEED.51 & Recycled Content in Infrastructure \\
LEED.52 & Solid Waste Management Infrastructure \\
LEED.53 & Light Pollution Reduction \\
\hline & INNOVATION AND DESIGN PROCESS \\
LEED.54 & Innovation and Exemplary Performance \\
LEED.55 & LEED $^{\circledR}$ Accredited Professional
\end{tabular}

REGIONAL PRIORITY CREDIT

LEED.56 Regional Priority 
Table S1.2 BREEAM Communities

Code Categories / Indicators

\begin{tabular}{|c|c|}
\hline & CLIMATE \& ENERGY \\
\hline BRE.1 & Flood and risk assessment (Location) \\
\hline BRE.2 & Surface water runoff \\
\hline BRE.3 & Rainwater SUDS \\
\hline BRE.4 & Heat Island \\
\hline BRE.5 & Energy Efficiency \\
\hline BRE.6 & Onsite Renewables \\
\hline BRE.7 & Future Renewable(s) \\
\hline BRE.8 & Services \\
\hline BRE.9 & Water consumption \\
\hline BRE.10 & Design-Weather Resilience \\
\hline \multirow[t]{2}{*}{ BRE.11 } & Sub/smart-metering \\
\hline & RESOURCES \\
\hline BRE.12 & Low impact \\
\hline BRE.13 & Locally sourced materials \\
\hline BRE.14 & Road Construction \\
\hline BRE.15 & Resource Efficiency \\
\hline BRE.16 & Groundwater \\
\hline \multirow[t]{2}{*}{ BRE.17 } & Land Remediation \\
\hline & PLACE SHAPING \\
\hline BRE.18 & Sequential Approach \\
\hline BRE.19 & Land Reuse \\
\hline BRE.20 & Building Reuse \\
\hline BRE.21 & Landscaping \\
\hline BRE.22 & Design and access \\
\hline BRE.23 & Green areas \\
\hline BRE.24 & Local Demographics \\
\hline BRE.25 & Affordable Housing \\
\hline BRE.26 & Secured by Design \\
\hline BRE.27 & Active Frontages \\
\hline BRE.28 & Defensive Spaces \\
\hline BRE.29 & Local Vernacular \\
\hline BRE.30 & Security Lighting \\
\hline BRE.31 & Form of Development-Connectivity \\
\hline \multirow[t]{2}{*}{ BRE.32 } & Form of Development-Pedestrian Movement \\
\hline & TRANSPORT \\
\hline BRE.33 & Location/Capacity \\
\hline BRE.34 & Availability-Frequency \\
\hline BRE.35 & Facilities \\
\hline BRE.36 & Local Amenities \\
\hline BRE.37 & Network-cycling \\
\hline BRE.38 & Facilities-cycling \\
\hline BRE.39 & Car clubs \\
\hline BRE.40 & Flexible parking-Traffic \\
\hline BRE.41 & Local parking-Traffic \\
\hline BRE.42 & Home Zones-Traffic \\
\hline BRE.43 & Transport Assessment-Traffics \\
\hline BRE.44 & Electric vehicle charching points-Low carbon transport \\
\hline BRE.45 & Transport Impacts-Road design \\
\hline \multirow[t]{2}{*}{ BRE.46 } & Commercial LGV Plan-Vehicular Access \\
\hline & COMMUNITY \\
\hline BRE.47 & Inclusive Design \\
\hline BRE.48 & Consultation \\
\hline BRE.49 & Development user guide \\
\hline \multirow[t]{2}{*}{ BRE.50 } & Management and operation \\
\hline & ECOLOGY \\
\hline BRE.51 & Ecological Survey \\
\hline
\end{tabular}


BRE.52 Biodiversity Action Plan

BRE.53 Native Flora

BRE.54 Wildlife corridors

BUSINESS

BRE.55 Business Priority Sectors

BRE.56 Labour and Skills

BRE.57 Employment

BRE.58 New business

BRE.59 Investment

BUILDINGS

BRE.60 Domestic-Code for sustainable homes

BRE.61 Domestic-Code for sustainable homes

BRE.62 Building refurbishment

INNOVATION

BRE.63 Innovation 
Table S1.3 CASBEE UD

\begin{tabular}{|c|c|}
\hline Code & Categories/Indicators \\
\hline & QUD1 Natural Environment (microclimates and ecosystems) \\
\hline & 1.1.1 Consideration and conservation of microclimates in pedestrian space in summer \\
\hline CASBEE.1 & 1.1.1.1 Mitigation of heat island effect with the passage of air \\
\hline CASBEE.2 & 1.1.1.2 Mitigation of heat island effect with shading \\
\hline CASBEE.3 & 1.1.1.3 Mitigation of heat island effect with green space and open water etc. \\
\hline \multirow[t]{2}{*}{ CASBEE.4 } & 1.1.1.4 Consideration for the positioning of heat exhaust \\
\hline & 1.1.2 Consideration and conservation of terrain \\
\hline CASBEE.5 & 1.1.2.1 Building layout and shape design that consider existing topographic character \\
\hline CASBEE.6 & 1.1.2.2 Conservation of topsoil \\
\hline \multirow[t]{2}{*}{ CASBEE.7 } & 1.1.2.3 Consideration of soil contamination \\
\hline & 1.1.3 Consideration and conservation of water environment \\
\hline CASBEE.8 & 1.1.3.1 Conservation of water bodies \\
\hline CASBEE. 9 & 1.1.3.2 Conservation of aquifers \\
\hline \multirow[t]{2}{*}{ CASBEE.10 } & 1.1.3.3 Consideration of water quality \\
\hline & 1.1.4 Conservation and creation of habitat \\
\hline CASBEE.11 & 1.1.4.1 Grasping the potential of the natural environment \\
\hline CASBEE.12 & 1.1.4.2 Conservation or regeneration of natural resources \\
\hline CASBEE.13 & 1.1.4.3 Creating ecosystem networks \\
\hline \multirow{2}{*}{ CASBEE.14 } & 1.1.4.4 Providing a suitable habitat for flora and fauna \\
\hline & 1.1.5 Other consideration for the environment inside the designated area \\
\hline CASBEE.15 & 1.1.5.1 Ensuring good air quality, acoustic and vibration environments \\
\hline CASBEE.16 & 1.1.5.2 Improving the wind environment \\
\hline \multirow[t]{3}{*}{ CASBEE.17 } & 1.1.5.3 Securing sunlight \\
\hline & QUD2 Service functions for the designated area \\
\hline & 1.2.1 Performance of supply and treatment systems(mains water, sewerage and energy) \\
\hline CASBEE.18 & 1.2.1.1 Reliability of supply and treatment systems \\
\hline \multirow[t]{2}{*}{ CASBEE.19 } & 1.2.1.2 Flexibility to meet changing demand and technical innovation in supply and treatment systems \\
\hline & 1.2.2 Performance of information systems \\
\hline CASBEE.20 & 1.2.2.1 Reliability of information systems \\
\hline CASBEE.21 & 1.2.2.2 Flexibility to meet changing demand and technical innovation in information systems \\
\hline \multirow[t]{2}{*}{ CASBEE.22 } & 1.2.2.3 Usability (information systems) \\
\hline & 1.2.3 Performance of transportation systems \\
\hline CASBEE.23 & 1.2.3.1 Sufficient capacity of transportation systems \\
\hline \multirow{2}{*}{ CASBEE.24 } & 1.2.3.2 Securing safety in pedestrian areas etc. \\
\hline & 1.2.4 Disaster and crime prevention performance \\
\hline CASBEE.25 & 1.2.4.1 Understanding the risk from natural hazards \\
\hline CASBEE.26 & 1.2.4.2 Securing open space as wide area shelter \\
\hline CASBEE.27 & 1.2.4.3 Providing proper evacuation routes \\
\hline \multirow[t]{2}{*}{ CASBEE.28 } & 1.2.4.4 Crime prevention performance (surveillance and territoriality) \\
\hline & 1.2.5 Convenience of daily life \\
\hline CASBEE.29 & 1.2.5.1 Distance to daily-use stores and facilities \\
\hline CASBEE.30 & 1.2.5.2 Distance to medical and welfare facilities \\
\hline CASBEE.31 & 1.2.5.3 Distance to educational and cultural facilities \\
\hline \multirow[t]{3}{*}{ CASBEE.32 } & 1.2.6 Consideration for universal design \\
\hline & QUD3 Contribution to the local community (history, culture, scenery and revitalization) \\
\hline & 1.3.1 Use of local resources \\
\hline CASBEE.33 & 1.3.1.1 Use of local industries, personnel and skills \\
\hline CASBEE.34 & 1.3.1.2 Conservation and use of historical, cultural and natural assets \\
\hline \multirow[t]{2}{*}{ CASBEE.35 } & 1.3.2 Contribution to the formation of social infrastructure \\
\hline & 1.3.3 Consideration for nurturing a good community \\
\hline CASBEE.36 & 1.3.3.1 Formation of local centres and fostering of vitality and communication \\
\hline \multirow[t]{2}{*}{ CASBEE.37 } & 1.3.3.2 Creation of various opportunities for public involvement \\
\hline & 1.3.4. Consideration for urban context and scenery \\
\hline CASBEE.38 & 1.3.4.1 Formation of urban context and scenery \\
\hline CASBEE.39 & 1.3.4.2 Harmony with surroundings \\
\hline
\end{tabular}


LRUD1 Environmental impact on microclimates, façade and landscape

2.1.1 Reduction of thermal impact on the environment outside the designated area in summer

CASBEE.40 2.1.1.1 Planning of building group layout and forms to avoid blocking wind

CASBEE.41 2.1.1.2 Consideration for paving materials

CASBEE.42 2.1.1.3 Consideration for building cladding materials

CASBEE.43 2.1.1.4 Consideration for reduction of waste heat

2.1.2 Mitigation of impact on geological features outside the designated area

CASBEE.44 2.1.2.1 Prevention of soil contamination

CASBEE.45 2.1.2.2 Reduction of ground subsidence

2.1.3 Prevention of air pollution affecting outside the designated area

CASBEE.46 2.1.3.1 Source control measures

CASBEE.47 2.1.3.2 Measures concerning means of transport

CASBEE.48 2.1.3.3 Atmospheric purification measures

2.1.4 Prevention of noise, vibration and odor affecting outside the designated area

CASBEE.49 2.1.4.1 Reduction of the impact of noise

CASBEE.50 2.1.4.2 Reduction of the impact of vibration

CASBEE.51 2.1.4.3 Reduction of the impact of odor

2.1.5 Mitigation of wind hazard and sunlight obstruction affecting outside the designated area

CASBEE.52 2.1.5.1 Mitigation of wind hazard

CASBEE.53 2.1.5.2 Mitigation of sunlight obstruction

2.1.6 Mitigation of light pollution affecting outside the designated area

CASBEE.54 2.1.6.1 Mitigation of light pollution from lighting and advertising displays etc.

CASBEE.55 2.1.6.2 Mitigation of sunlight reflection from building facade and landscape materials

LRUD2 Social infrastructure

2.2.1 Reduction of mains water supply (load)

CASBEE.56 2.2.1.1 Encouragement for the use of stored rainwater

CASBEE.57 2.2.1.2 Water recirculation and use through a miscellaneous water system

2.2.2 Reduction of rainwater discharge load

CASBEE.58 2.2.2.1 Mitigation of surface water runoff using permeable paving and percolation trenches

CASBEE.59 2.2.2.2 Mitigation of rainwater outflow using retaining pond and flood control basins

2.2.3 Reduction of the treatment load from sewage and graywater

CASBEE.60 2.2.3.1 Load reduction using high-level treatment of sewage and graywater

CASBEE.61 2.2.3.2 Load levelling using water discharge balancing tanks etc.

2.2.4 Reduction of waste treatment load

CASBEE.62 2.2.4.1 Reduction of collection load using centralized-storage facilities

CASBEE.63 2.2.4.2 Installation of facilities to reduce the volume and weight of waste and employ composting

CASBEE.64 2.2.4.3 Classification, treatment and disposal of waste

2.2.5 Consideration for traffic load

CASBEE.65 2.2.5.1 Reduction of the total traffic volume through modal shift

CASBEE.66 2.2.5.2 Efficient traffic assignment on local road network

2.2.6 Effective energy use for the entire designated area

CASBEE.67 2.2.6.1 Area network of unused and renewable energy

CASBEE.68 2.2.6.2 Load levelling of electrical power and heat through area network

CASBEE.69 2.2.6.3 Area network of high-efficient energy system

\section{LRUD3 Management of the local environment}

2.3.1 Consideration of global warming

CASBEE.70 2.3.1.1 Construction and materials, etc. (global warming)

CASBEE.71 2.3.1.2 Energy (global warming)

CASBEE.72 2.3.1.3 Transportation (global warming)

2.3.2 Environmentally responsible construction management

CASBEE.73 2.3.2.1 Acquisition of ISO14001 certification

CASBEE.74 2.3.2.2 Reduction of by-products of construction

CASBEE.75 2.3.2.3 Energy saving activity during construction

CASBEE.76 2.3.2.4 Reduction of construction-related impact affecting outside the designated area

CASBEE.77 2.3.2.5 Selection of materials with consideration for the global environment

CASBEE.78 2.3.2.6 Selection of materials with consideration for impact on health

2.3.3 Regional transportation planning

CASBEE.79 2.3.3.1 Coordinating with the administrative master plans for transportation system

CASBEE.80 2.3.3.2 Measures for transportation demand management

2.3.4 Monitoring and management system 
CASBEE.81 2.3.4.1 Monitoring and management system to reduce energy usage inside the designated area

CASBEE.82 2.3.4.2 Monitoring and management system to conserve the surrounding environment of the designated area 


\section{Table S1.4 ECOCITY}

\subsection{NATURAL ENVIRONMENT}

1.1.1 strive for the protection of the surrounding landscape and its natural elements

ECO.1 Consider the boundaries of the city as a zone for exchange between the city and surroundings (water cycle, vegetation, wildlife, recreation) and create conditions for the penetration of the surrounding landscape into the city.

ECO.2 Establish sound measures to avoid unplanned future extensions of settlements.

ECO.3 Strive for a recreation of landscape/natural habitats in areas with a declining population or industry ("shrinking cities").

ECO.4 Preserve bio-diversity and habitats in the surrounding landscape.

ECO.5 Minimise the impact of harmful substances on vegetation, wildlife and water systems.

ECO.6 Preserve or re-establish green corridors on the regional and municipal scale as open-space connections.

Offer recreational areas in the surrounding landscape with attractive connections from the urban area to help people relate to the natural environment and to offer opportunities for weekend recreation close to residential areas.

ECO.8 Develop and foster sustainable regional agriculture (e.g. organise direct marketing of regional food), forestry and tourism, also maintaining the cultural landscape.

ECO.9 Use surplus biomass from regional agriculture and forestry for energy generation.

1.1.3 Plan in accordance with the climatic, topographical and geological setting

ECO.10 Use (and preserve) landscape and topographic elements that are important for the urban climate (e.g. groves and forests as cold air sources, lakes as climatic balancing elements, valleys and mountain sides as air exchange corridors) and avoid barriers in air exchange corridors.

ECO.11 Keep industry and unavoidable sources of air pollution out of areas and corridors which are important for the urban climate and consider the main wind directions when expanding settlement areas.

ECO.12 Consider the local climatic conditions for the design of public spaces (wind protection, roofs as rain protection, exposure to the sun, shadowing elements) and for building design (shape, materials, energy concept, etc.).

ECO.13 Take the local topography into account for the transport systems (e.g. for walking and cycling pathways), for energyefficiency (e.g. by avoiding settlements on shadowy northern inclinations) and for water systems (e.g. rainwater management on the surface).

ECO.14 Plan with the geological conditions (soil, groundwater, etc.) e.g. for urban greenery, rainwater management and constructing buildings.

\subsection{BUILT ENVIRONMENT}

1.2.1 Strive for a polycentric, compact and transit-oriented urban structure

ECO.15 Strive for a polycentric structure of the city with good accessibility of basic facilities and of the city centre as the main provider of higher-order infrastructures and working places.

ECO.16 Organise the city as a network of mixed-use urban quarters with individual characteristics and identities.

ECO.17 Concentrate urban development at sites with a high potential for public transport, locating new settlements (and new buildings in existing settlements) along (potential) axes of public transport (Transit Oriented Development), and avoid developments that disturb open-space patterns between these axes (green fingers).

ECO.18 Integrate new and existing developments into public transport and communication networks on the local, metropolitan, regional, national and global scale.

ECO.19 Strive for land management on the regional and local scale.

ECO.20 Structure prices and subsidies to achieve changes in development patterns and the transportation system (e.g. building subsidies, road pricing, PT fares etc. differentiated according to location and time).

1.2.2 Consider concentration and decentralisation for supply and disposal systems

ECO.21 Consider the decentralised concentration of energy supply systems such as district heating networks (rather than either huge community heating systems on the scale of entire cities or quarters or very small individual systems).

ECO.22 Maximise the share of renewable energy sources on the regional and local level (e.g. wind power stations or biomass cogeneration power plants from regional sources).

ECO.23 Strive for the decentralisation of wastewater treatment on the site (wastewater wetland facilities) or in buildings (grey water purification plants). 
ECO.25 Offer possibilities for composting and re-using organic waste on site.

1.2.3 Promote use, re-use and revitalisation of the cultural heritage

ECO.26 Respect the cultural heritage of the region regarding the historical urban grain (e.g. phases of growth and development, hierarchy and design of street network, texture of building lots, land-use patterns).

ECO.27 Refer to the regional and local building typologies (also regarding protection from sun, wind, rain, snow, etc.), regional culture for living, aesthetics based on local craft skills, etc. and strive to maintain and re-use existing elements such as buildings, open-space elements and infrastructure (also as a contribution to a genius loci based on the continuity of the urban cultural heritage).

\section{URBAN STRUCTURE}

\subsection{DEMAND FOR LAND}

2.1.1 Promover la reutilización de suelo y de las edificaciones existentes para reducir la demanda de suelo y de nuevas edificaciones

ECO.28 Strive for a compact city using all possibilities for internal development e.g. in gaps between blocks or buildings (but avoiding overcrowding and ensuring adequate green spaces).

ECO.29 Prioritise the reuse of existing sites (brown field developments) in suitable locations.

ECO.30 Minimise the share of vacant dwellings, buildings and plots through municipal management (e.g. register of available plots/properties within the city, activities for inner city developments).

2.1.2 Develop structures of qualified high density

ECO.31 Aim at qualified high density to reduce land consumption and to promote a high social density as well as to promote viability and cost effectiveness of public transport, community heating systems and provision of basic facilities.

ECO.32 Consider issues which limit density such as passive and active use of solar energy, good day-lighting conditions, sufficient open spaces, surfaces for water management, air exchange corridors.

ECO.33 Concentrate the highest development densities around public transport stops.

ECO.34 Use compact and multi-storey building typologies for residential housing and commercial uses.

ECO.35 Consider increasing density by minimising land-demand for motorised traffic and parking.

\subsection{LAND USE}

2.2.1 Organise a balance of residential, employment and educational uses as well as supply (of goods and services), and social and recreational facilities

ECO.36 Provide a balanced ratio of residential housing and working places.

ECO.37 Provide a balanced ratio of residential housing and commercial units (especially retail for daily needs) as well as cultural, educational and social facilities (e.g. kindergarten, primary, secondary schools, general practitioners, pubs restaurants).

ECO.38 On new sites, include facilities attracting inhabitants of the entire community as focal points (community building).

ECO.39 Maintain and strengthen existing mix of uses while adding new uses into existing mono-functional areas.

ECO.40 Ensure that these facilities are distributed well to enable short travel distances (on foot, by bike or by public transport) within the neighbourhood or the city.

2.2.2 Enable fine-meshed, mixed-use structures at building, block or neighbourhood level

ECO.41 Strive for variability and flexibility of urban and building structures to facilitate changes of use over time.

ECO.42 Optimise the locations for mixed-use at building level (e.g. with commercial uses on the lower floors, residential uses higher up) or at block level (with commercial buildings on the northern edge of blocks or with west or east orientation).

ECO.43 Create differentiated areas with different meshes of mixed structures and different ratios of uses.

\subsection{PUBLIC SPACE}

2.3.1 Provide attractive and liveable public space for everyday life, including considerations of legibility and connectivity

ECO.44 Plan for sufficient public space (squares, convivial streetscapes, green areas) close to living and working environments.

ECO.45 Strive for multi-functionality (avoid mono-functionality) and a strong identity of public spaces.

ECO.46 Create varying urban fabrics of open spaces, building typologies and landscape elements for vivid neighbourhoods with a distinctive genius loci.

ECO.47 Plan a hierarchical system of public spaces (squares, parks, streetscapes) that is interconnected through pedestrian networks and provides changing attractions along spatial sequences; avoid architectural barriers. 

quality of possible social contacts in (high density) neighbourhood areas (e.g. in neighbourhood centres).

ECO.49 Orientate buildings towards public spaces (windows, entrances, attractive ground floor facades, which front appropriate uses).

ECO.50 Provide open-space elements and architecture of high aesthetic quality (water design, surfaces in streets and squares, facades, street furniture, etc.), enabling a variety of sensory experiences, also for children.

ECO.51 Minimise the share of road space provided solely for motor vehicles and the disturbance of public spaces by motorised traffic (bearing in mind especially safety and noise issues).

\subsection{LANDSCAPE / GREEN SPACES}

2.4.1 Integrate natural elements and cycles into the urban tissue

ECO.52 Create and conserve habitats for urban wildlife (animals and plants) and habitat networks (use linear elements to connect open spaces, avoid barriers, create stepping-stone habitats, consider ecological bridges), including green corridors into the surrounding landscape.

ECO.53 Maximise soft landscaping areas for planting (at ground level as well as on facades and roofs).

ECO.54 Create, maintain or recultivate/restore green and water elements within the city (trees, hedges, grassland, planting areas and containers, watercourses, fountains, etc.), especially those of bioclimatic importance.

ECO.55 Maintain the natural embankments and shore areas of surface waters (ponds, lakes, streams or rivers), where necessary restore them.

ECO.56 Minimise sealed surfaces (footprints of buildings, treatment of pavements, parking spaces, etc.).

ECO.57 Strive for a balanced hierarchy of public, semi-public and private green spaces, providing opportunities for gardening for the inhabitants, considering also city farms in appropriate locations.

ECO.58 Offer accessible areas to provide children with personal experience of and conscious perception of the natural environment.

\subsection{URBAN COMFORT}

2.5.1 Strive for a high daily, seasonal and annual outdoor comfort

ECO.59 Consider the exposure of public spaces to bioclimatic conditions (light, wind, sun, rain, snow, etc.) to permit the use of public spaces throughout the day and the seasons.

ECO.60 Develop the geometry of quarters and neighbourhoods according to the requirements of urban ventilation (choose climatically favourable layouts and materials for green spaces, blocks and buildings).

ECO.61 Plan for and use water surfaces (e.g. as part of a rainwater management systems) to improve urban comfort and to contribute to natural ventilation on the block or building level.

ECO.62 Increase the absorption capacity of urban land for rainwater (and the filtering capacity for emissions) by planting and maintaining trees and other vegetation, constructing green roofs and facades and by leaving ground unsealed where appropriate.

ECO.63 Reduce the impact of infrastructure for mobile telecommunications, electricity supply, electric railway systems and other technical devices on people's health and well-being (avoiding their exposure to electromagnetic radiation by keeping sufficient distances and using screening materials and structures).

2.5.2 Minimise noise and air pollution

ECO.64 Avoid noise emissions at source by taking active measures to reduce emissions from traffic, commercial uses, leisure and sports activities.

ECO.65 Improve the air quality by reducing gaseous and particulate emissions from traffic, commercial and industrial units, power stations and household heating systems at source.

ECO.66 Control imissions through passive measures (sufficient distances, protective walls/embankments, shelterbelt plantings, layout of blocks, buildings and floors).

ECO.67 Minimise the impact of construction works on urban comfort.

\subsection{BUILDINGS}

2.6.1 Maximise indoor comfort and resource conservation throughout the lifecycle of buildings

ECO.68 Maintain and re-use existing buildings for existing uses or convert them for new uses and promote their refurbishment (especially regarding energy demand and supply).

ECO.69 Strive for low-energy or passive-house standard in terms of construction and heating, ventilation and air-conditioning (HVAC) equipment (building services).

ECO.70 Use building materials which are 'healthy' in production, construction, use and demolition.

ECO.71 Maximise the durability, detachability and the recyclability of materials and structures.

ECO.72 Allow for reverse-engineering, e.g. to enable later installation of HVAC equipment (building services).

ECO.73 Reduce maintenance requirements of buildings.

2.6.2 Plan flexible, communicative and accessible buildings 
ECO.74 Use flexible building designs to facilitate change of use over time (e.g. from residential to commercial) as well as transformation and adaptation of internal spaces by the user.

ECO.75 Strive for the close connections of buildings to public spaces and for active frontages (facades, allocation of uses and entrances), avoiding architectural barriers to accessibility (lay-out of buildings causing detours, steps, etc.).

ECO.76 Strive for communicative buildings with innovative ideas for living.

ECO.77 Seek new housing concepts for senior citizens including mixed generation housing concepts ('young and old' projects).

ECO.78 Consider that buildings are suitable for mixed-use structures (e.g. for commercial uses on the lower floors, residential uses higher up).

3. TRANSPORT

\subsection{SLOW MODES/PUBLIC TRANSPORT}

3.1.1 Minimise distances (in time and space) between activities to reduce travel demand

ECO.79 Design pedestrian-oriented urban structures with short distances (see density, mixed use) also situating buildings so that they allow the planning of pedestrian networks without long detours (also avoiding main traffic arteries, which are difficult to cross, within a neighbourhood).

ECO.80 Integrate all important destinations (shops, schools, major employment locations) within mixed use neighbourhoods and/or close to public transport stops and ensure good connections to external destinations.

ECO.81 Create high quality open spaces and structures (squares, parks, streetscapes, etc.) close to residential areas to reduce demand for leisure travel.

3.1.2 Give priority to pedestrian and cycle paths as the main network for internal neighbourhood traffic

ECO.82 Interconnect pedestrian and cycle paths to a dense network, which is as far as possible independent from major routes for motorised travel but not so isolated as to create security problems.

ECO.83 Integrate public spaces and streetscapes of high spatial quality and changing public activities into the network for non-motorised modes (for attractive walking/cycling and for social control).

ECO.84 Plan for an attractive cycling network that allows speedy circulation also beyond the neighbourhood scale.

ECO.85 Eliminate danger and disturbances from motorised traffic.

ECO.86 Provide barrier-free accessibility to transport networks and buildings for everyone - including the handicapped and those with prams, pushchairs or carts to transport goods.

ECO.87 Provide attractive supporting infrastructure for pedestrians - with e.g. continuous weather protection (arcades, passages, roofed pavements) along the main routes as well as benches/seats - and for cyclists (parking and storage facilities for bikes, weather protection, etc.).

3.1.3 Give priority to public transport for the connections beyond the neighbourhood level

ECO.88 Integrate well-aligned public transport lines and corridors (close to people and allowing rapid connections) into the urban structure and design the structure of a new neighbourhood around the (optimised) routes of public transport.

ECO.89 Develop an integrated system of public transport (demand-responsive transport services, bus, light rail, heavy rail) to provide connections both within the municipalities and in regional networks and provide bike \& ride / kiss \& ride facilities at stops and interchanges.

ECO.90 Optimise distances between public transport stops to maximise rider catchments and provide central stops in the centre of new neighbourhoods.

ECO.91 Allocate stops to uses and vice versa in such a way that the majority of important public facilities are situated near the stops.

3.1.4 Provide mobility management measures to support modal shift to environmentally compatible modes

ECO.92 Establish mobility centres providing comprehensive and easily accessible information on local public transport and railway including schedules and inter-modal travel options (mobility help-desk, internet platform) and offering comprehensive services for diverse transport demands (e.g. sale of public transport tickets; reservation for demand responsive transport; bicycle station for parking, repair, hire, etc.; car-sharing and hire systems, ride-share agency).

ECO.93 Provide real-time information on timetables for passengers at stations, in vehicles and on the internet (arrivals, departures, connections and schedule changes) from a control station.

ECO.94 Target new households with tailored advice on mobility alternatives, possibly including introductory offers on public transport season tickets, car clubs, etc.

ECO.95 Offer „mobility packages“, e.g. including car sharing offers, public transport information, reduced cost season ticket, low cost home delivery services, discounts on taxi services, etc. 


\subsection{INDIVIDUAL MOTORISED TRAVEL}

ECO.97 Reduce the speed of motorised traffic by using traffic calming measures and appropriate regulations.

ECO.98 Strive for a differentiated shape and hierarchy of the road network (lane width, speeds, etc.) with lower levels of the hierarchy not dominated by motorised traffic (e.g. home zones, bicycle streets) and with minimum through traffic.

ECO.99 Plan car-free or car-reduced areas of sufficient size to allow all the advantages of living and moving without a car to be experienced.

ECO.100 Minimise land consumption for motorised traffic (length and width of streets, areas for parking).

ECO.101 Promote efficient use of cars (e.g. through car-sharing or an agency for ride-sharing).

ECO.102 Restrict access to particular areas for non-public motorised traffic (e.g. to city or neighbourhood centres).

3.2.2 Support the reduction of motorised traffic through parking management

ECO.103 Reduce the provision of parking spaces (i.e. the required ratio of parking space per dwelling or work space), especially in central areas with good public transport access; develop car-reduced and car-free areas.

ECO.104 Manage demand for parking through parking charges in central areas to reduce car traffic there.

ECO.105 Minimise parking spaces in public areas to reduce the impact of private cars on the quality of public spaces and reduce overall land consumption for remaining parking places (multi-storey parking, mechanical systems).

ECO.106 Concentrate parking spaces in collective car parks and district parking garages within an acceptable distance to dwellings and not directly at the front door or even inside residential buildings (locating district parking lots at least the same average distances away as public transit stops).

\subsection{TRANSPORT OF GOODS}

3.3.1 develop a neighbourhood logistics and delivery concept to minimise the need for individual load carrying by car

ECO.107 Organise a neighbourhood logistics system (neighbourhood logistics / distribution centre, shopping boxes, etc.) including co-ordinated goods delivery to private households (also for products ordered via e-commerce); using alternatively fuelled vehicles (e.g. electricity from renewable sources or hydrogen).

ECO.108 Integrate locations for waste collection and storage facilities (containers, etc.) in the urban and building structure to ensure efficient access for collection vehicles.

ECO.109 Locate facilities generating demand for goods transportation at sites allowing short distances for city logistics.

ECO.110 Use information system technologies to optimise routes of delivery, waste collection and (construction) material transport.

3.3.2 Plan efficient construction logistics

ECO.111 Promote the use of local materials to minimise construction traffic.

ECO.112 Plan the re-use of excavation materials on-site as far as possible.

ECO.113 Organise necessary construction traffic (removal, delivery, distribution) in an effective way.

\section{ENERGY AND MATERIAL FLOWS}

\subsection{ENERGY}

4.1.1 Optimise energy efficiency of the urban structure

ECO.114 Design compact settlements and compact buildings weighing up low surface to volume ratios against the need for solarisation (next measure) and day-lighting.

ECO.115 Solarise the urban structure: layout of buildings for passive heating/cooling and for natural day-lighting (orientate buildings to the sun, avoid shading by optimising the heights of buildings in relation to distances between them, design roofs to use solar applications efficiently).

ECO.116 Strive for high-density developments enabling the economic application of district heating systems or co-generation plants.

4.1.2 Minimise energy demand of buildings

ECO.117 Reduce energy losses by striving for a high insulation standard in new and existing buildings (low energy houses, passive-houses) and for a compact design of buildings (low surface-to-volume ratio).

ECO.118 Reduce the heating demand in temperate and cold climates by maximising passive solar energy gains (i.e. high ratio of windows and glass facades on south facades). 
ECO.119 Reduce energy demand for cooling in hot climates by reducing uncontrollable solar irradiation into buildings (including devices for protection against overheating, e.g. shades, blinds, etc.) and by reducing the electricity consumption (to avoid additional internal heat generation i.e. through computers, electric devices).

ECO.120 Reduce electricity demand through efficient lighting systems, natural day-light systems (reflectors, light-shelves, light pipes).

ECO.121 Reduce hot water consumption through use of water saving installations.

ECO.122 Use efficient ventilation systems (controlled ventilation, heat recovery, natural ventilation systems including indoor planting zones, do not use conventional air-conditioning).

ECO.123 Use efficient cooling systems (cooling of concrete components, ground ducts, absorption heat pumps, indoor planting zones, water elements, atriums and courtyards).

4.1.3 Maximise the efficiency of energy use and supply

ECO.124 124. Use efficient heating, ventilating and cooling equipment as well as electrical devices controlled by IT based facility management.

ECO.125 Use energy-saving lighting appliances in buildings and for public space.

ECO.126 Use co-generation plants (CHP) for district heating networks of appropriate size for short pipe lengths preferentially, when demand for heat ensures a useful application of the waste heat.

4.1.4 Give preference to renewable sources for energy supply

ECO.127 Use solar energy, biomass and/or heat recovery for room heating/cooling and water heating.

ECO.128 Use photovoltaics, wind engines and/or biomass co-generation plants.

ECO.129 Provide surfaces for active solar systems on roofs and facades.

\subsection{WATER}

4.2.1 Minimise primary water consumption

ECO.130 Use water saving devices for baths, toilets, kitchens etc. and where appropriate use compost toilets.

ECO.131 Collect rainwater for use in toilets, washing machines, gardening, car wash, etc.

ECO.132 Recycle grey water (all domestic waste water but faeces) for use in toilets, washing machines, gardening, car wash, etc.

ECO.133 Use an efficient watering system for green areas (and preferably use plants with low water demand).

4.2.2 Minimise impairment of the natural water cycle

ECO.134 Maximise permeability of urban soil and paved surfaces (e.g. parking and play areas, informal foot \& cycle paths, etc.).

ECO.135 Strive for unsealing of existing sealed surfaces where appropriate.

ECO.136 Practise storm water management using rain water retention and infiltration measures to maintain the natural water balance and relieve the waste water treatment plants (green roofs, infiltration swales and hollows, trench drain infiltration, retention ponds) taking into account natural flow rates.

ECO.137 Avoid infiltration of natural water cycles by polluted effluent (discharge) (such as from extensive metallic surfaces e.g. zinc and copper roofs and from intensively used traffic areas) and/or use filter technologies.

ECO.138 Maintain or revitalise natural water bodies (ponds, lakes streams and rivers with soft embankments).

ECO.139 Use rainwater fed landscaping elements to provide a sensory experience to increase the quality of public space, to improve urban comfort and to make people aware of water cycle.

ECO.140 Where appropriate purify black and grey water in wastewater wetland areas on site (e.g. reed-bed sewage treatment).

\subsection{WASTE}

4.3.1 Minimise the volume of waste generated and of waste going to disposal

ECO.141 Promote sharing of goods and devices ("sharing instead of ownership") by supporting the exchange of goods and providing hire / loan services in neighbourhoods.

ECO.142 Promote re-use and recycling of waste by separately collecting valuable products and providing interim storage and collection services.

ECO.143 Promote composting systems for treating the biological fractions of waste on site.

ECO.144 Avoid the disposal of untreated waste and creation / disposal of waste with negative impacts on health, well-being and the environment.

ECO.145 Minimise the amount of excavated material to be disposed of (during construction phases) by reducing the amount of soil to be excavated and by using the excavated soil on site, e.g. as building material (concrete aggregates, refilling), as landscaping material, for noise embankments, as cover material, for backfilling, etc.

ECO.146 Maximise separate collection and recycling of construction / demolition rubble (preferably on site).

\subsection{BUILDING MATERIALS}

4.4.1 Minimise primary building material consumption and maximise recyclability of materials

ECO.147 Maximise the re-use of buildings and building components. 
ECO.149 Reduce the demand for building materials by reducing hard transport surfaces (particularly tarmacked roads for motorised traffic), by reducing basement areas and by designing lightweight constructions (e.g. timber).

ECO.150 Use recycled materials.

ECO.151 Consider the construction, use and deconstruction phases of buildings when selecting materials (design for recycling): maximise detachability (e.g. screws instead of glue), reusability and recyclability of materials (possibility for re-use of structures is preferential to practicable material recovery); consider reverse-engineering for hvac equipment (building services, supply networks).

ECO.152 Introduce a building inventory (Material Accounting System): information on quantity and quality (i.e. composition) of all building materials to document the recycling as well as pollutant potential of the building.

ECO.153

4.4.2 Maximise the use of environmentally friendly and non-hazardous building materials

ECO.154 Use materials of high durability.

ECO.155 Maximise the use of recycled materials for buildings (e.g. recycle concrete or building rubble on site)

ECO.156 Maximise the share of renewable materials (e.g. timber structures, paper pellets for insulation).

ECO.157 Avoid harmful substances (e.g. pvc, solvents, phthalates).

ECO.158 Use building materials with a low demand for primary and non-renewable energy.

\section{SOCIO-ECONOMY}

\subsection{SOCIAL ISSUES}

5.1.1 Promote social diversity and integration for a balanced social structure

ECO.159 Aim at a mixed population in terms of income, age, cultural background and lifestyle concepts.

ECO.160 Provide a balanced variety of dwelling types for different population groups (e.g. singles, families, senior citizens) and ownership models (owner-occupied flats and rented apartments, including subsidised / social housing).

ECO.161 Consider social diversity and integration early on in the planning stage since the planning processes for different types of projects (types of accommodation, target user groups) vary considerably.

ECO.162 Ensure participation of citizens, stakeholders and users in decision-making throughout all phases of the project.

ECO.163 Increase the identification of people with the new development by starting participation processes early on in the planning process and by establishing building cooperatives (fostering contacts among future neighbours before moving to new dwellings).

5.1.2 Provide social and other infrastructure with good accessibility

ECO.164 Provide social services (child care, care for the elderly and other persons in need of support) and health care services (general practitioner, pharmacy etc.) within walking distances (from public transport stops) for most people.

ECO.165 Provide retail facilities for daily needs easily accessibly on foot and by bike.

\subsection{ECONOMY}

5.2.1 Offer incentives for businesses and enterprises to move to the area

ECO.166 Use regional and local economic strengths for attracting businesses and enterprises.

ECO.167 Take existing and emerging regional clusters of businesses into account when selecting businesses to be addressed

ECO.168 Investigate the possibility of offering start-up credits (are there local credit institutions and are they willing to provide loans?) for appropriate small and medium sized enterprises (SMEs) wanting to establish themselves in the area.

ECO.169 Prepare targeted information on access to markets for appropriate goods and services (e.g. can businesses find suppliers and customers in the area and are there markets that can easily be opened up from the location in question?).

ECO.170 Favour SMEs, which are appropriate for fine meshed, mixed-use structures.

ECO.171 Pay attention to the "communication potential" by providing good access to the transport network and information and communication media.

5.2.2 Use the available labour resources

ECO.172 Analyse the strengths and local specifics of the labour force including the availability of workers with different qualifications.

ECO.173 Where possible, promote the employment of people living near to their work places.

ECO.174 Where possible, promote the relocation of employees (potential commuters) to dwellings near their working places.

ECO.175 Look for particular educational institutions (e.g. universities) that enhance the attractiveness of the location. 


\subsection{COSTS}

5.3.1 Strive for a long-lived economic infrastructure

ECO.176 Consider the availability of land in the planning area at fair prices (comparison of land prices in this area and in others, restrictions regarding the usage / purchase of land in this area in comparison to others).

ECO.177 Consider potential problems with respect to property rights (does the acquisition of land constitute a problem?).

ECO.178 Consider life-cycle cost models for infrastructure integrating all costs (many ecological measures with higher investment cost lead to lower operating costs and resulting lower life-cycle cost).

ECO.179 Develop a compact urban form with sufficient density as a precondition for attractive and economically viable public transport systems and retail services as well as lower costs for the technical infrastructure (length of energy and water supply networks per head of population, etc.).

ECO.180 Seek alternative models to finance ecological infrastructure (i.e. sale of shares for photovoltaic solar power plants, green electricity collectives).

ECO.181 Consider contracting models for operating the technical infrastructure (e.g. companies operating co-generation plants (chp) or wood chip energy supply facilities).

5.3.2 Offer low cost housing, workplaces and space for non-profit uses

ECO.182 Minimise life-cycle costs for buildings (construction, operation, recovery, disposal).

ECO.183 Integrate high-density areas with compact building typologies to decrease construction costs and proportional plot costs.

ECO.184 Offer low-price dwellings through special procedures for low price plots (e.g. Städtebauliche Entwicklungsmaßnahme24), long-term plot-lease, etc.) as well as through low construction costs and thus low sales costs in order to give more social groups the possibility to own property.

ECO.185 Minimise construction costs for buildings through selection of appropriate materials and heating, ventilation and airconditioning systems, prefabricated modules, appropriate tendering procedures.

ECO.186 Provide conditions for lower household expenditure (i.e. in car-free areas with high-quality provision for other modes; through energy efficient buildings, etc.).

ECO.187 Provide favourable conditions for establishing building cooperatives (advice, long-term lease options for plots, etc.) such groups generally achieve lower building costs than developers.

ECO.188 Minimise maintenance and operating costs by selecting appropriate materials and HVAC systems and building services.

ECO.189 Offer semi-refurbished existing buildings or new buildings, which are not ready-to-use (i.e. needing some work input from the future users) as an offer to non-profit or low-profit uses. 


\section{PRESERVE AND ENHANCE HERITAGE AND CONSERVE RESOURCES}

\subsection{Reduce energy consumption and improve energy management}

INDI.1 1.1.1 Percentage of households with heating - ventilation - insulation better than the average of existing stock (lower consumption than the national average)

INDI.2 1.1.2 Percentage of park buildings with new heating - ventilation - insulation better than that required by regulation (RT 2000-Réglementation thermique)

INDI.3 1.1.3 Measures to save energy consumption in the residential and tertiary sector

INDI.4 1.1.4 Amount of energy costs in the social housing sector

INDI.5 1.1.5. Energy consumption of public buildings

INDI.6 1.1.6 Energy consumption of public lighting.

INDI.7 1.1.7 Percentage of homes and public buildings (including lighting) that use renewable energy

INDI.8 1.1.8 Measures to reduce greenhouse gases emissions caused by heating residential buildings and public tertiary

\subsection{Improve water resources management and quality}

INDI.9 1.2.1 Water consumption in the residential sector

INDI.10 1.2.2 Percentage of public facilities using water-saving techniques

INDI.11 1.2.3 Percentage of residential and commercial buildings reusing rainwater

INDI.12 1.2.4 Percentage of stormwater managed in the urban plot from waterproofed areas.

INDI.13 1.2.5 Quality of the sewage network

\subsection{Avoid urban sprawl and improve space management}

INDI.14 1.3.1 Urban density

INDI.15 1.3.2 Area of public open space per capita available (depending on the location of the neighbourhood)

INDI.16 1.3.3 Percentage of brownfield and contaminated land

INDI.17 1.3.4 Number of criteria in the implementation and regulation of the Local Town Planning Plan (compared with $21 \%$ obj. Of HQE2R)

\subsection{Optimise the use of materials (raw materials) and their management}

INDI.18 1.4.1 Percentage of constructed / rehabilitated / demolished buildings that use recycled / environmental labelling / environmental certifications or standards / ACV standards of materials and equipment.

INDI.19 1.4.2 Percentage of public facilities constructed / renovated / demolished, including an environmental quality approach

\subsection{Preserve and enhance what has been built and natural heritage}

INDI.20 1.5.1 Measures to preserve and enhance architectural heritage

INDI.21 1.5.2 Percentage of green space subjected to measures to preserve or enhance natural heritage and biodiversity

2. IMPROVE THE QUALITY OF THE LOCAL ENVIRONMENT

2.1 Preserve and enhance the landscape and visual quality

INDI.22 2.1.1 Requirements and measures taken to maintain or improve the quality of entries, the neighbourhood and continuity of spaces.

INDI.23 2.1.2 Measures and requirements to be considered in urban furniture and the visual quality of public lighting. 2.2 Improve the quality of housing and buildings

INDI.24 2.2.1 Building shabby facades (in the urban environment of the district to be treated)

INDI.25 2.2.2 Percentage of projects or constructed or renovated buildings that take into account the context and immediate environment (orientation, ventilation, insolation, shade, proximity to public transport, etc.)

INDI.26 2.2.3 Number of vacant homes.

INDI.27 2.2.4 Number of adapted housing in new developments or housing that can be adapted for the elderly and disabled

2.3 Improve cleanliness, hygiene and health

INDI.28 2.3.1 Importance of public and private spaces that are poorly maintained

INDI.29 2.3.2 Percentage of unhealthy dwellings that do not meet standards of comfort

INDI.30 2.3.3 Proportion of overcrowded housing ( 2 children or more per room)

INDI.31 2.3.4 Medical supply: public or private sector or hospitals

2.4 Improve safety and risk management (housing and neighbourhood)

INDI.32 2.4.1 Number of crimes, and theft crimes per 1,000 citizens

INDI.33 2.4.2 Number of victims of trafficking involving pedestrians and two-wheelers per 1,000 inhabitants

INDI.34 2.4.3 Proportion of the population exposed to hazardous products or materials requiring special monitoring

INDI.35 2.4.4 Proportion of the population exposed to natural unprotected hazards

$\mathbf{2 . 5}$ Improve air quality (indoors and surroundings)

INDI.36 2.5.1 Proportion of new buildings that meet specifications for indoor air quality.

INDI.37 2.5.2 Proportion of the population exposed to $\mathrm{NO}_{2}$ pollution exceeding $50 \mathrm{ug} / \mathrm{m}^{3}$ average annual hourly 
INDI.39 2.6.1 Percentage of the population exposed to noise

INDI.40 2.6.2 Proportion of the population exposed to noise of $65 \mathrm{~dB}(\mathrm{~A})$ Leq and between 18:00 to 10:00 p.m.

INDI.41 2.6.3 Proportion of construction / demolition / rehabilitation considering the noise problem for residents

2.7 Minimise waste and improve management

INDI.42 2.7.1 Proportion of household waste collected by sorting and separate collection

INDI.43 2.7.2 Proportion of construction / demolition / rehabilitation that considers waste management

\section{ENHANCE DIVERSITY}

\subsection{Ensure the diversity of the population}

INDI.44 3.1.1 Diversity of the workforce by professional category

INDI.45 3.1.2 Employment rate (employed persons / population of working age)

INDI.46 3.1.3 Population distribution by age

3.2 Ensure diversity of functions (economic and social)

INDI.47 3.2.1 Number of jobs per 1,000 inhabitants

INDI.48 3.2.2 Number of points of sale per 1,000 persons

INDI.49 3.2.3 Number of facilities and public services within $300 \mathrm{~m}$ of homes

\subsection{Ensure diversity of housing supply}

INDI.50 3.3.1 Diversity of housing according to their status: owner-occupied, private rental, social, public, etc.

INDI.51 3.3.2 Diversity of housing by size

INDI.52 3.3.3 Diversity of housing by type: single, grouped individually, small group, large scale, etc.

\section{ENHANCE INTEGRATION}

4.1 Increase levels of education and skills.

INDI.53 4.1.1 Proportion of children leaving primary school late.

INDI.54 4.1.2 Truancy rate

INDI.55 4.1.3 Number of cases of violence and crime in schools in the area.

4.2 Promote public access to employment, services and facilities of the city

INDI.56 4.2.1 Population living within $300 \mathrm{~m}$ of a facility or public service, or public transport stop, to travel directly to equipment or a public service.

INDI.57 4.2.2 Unemployment rate

INDI.58 4.2.3 Presence of urban voids between the district and the city-district or facilities or attractions.

4.3 Improve the attractiveness of the area by creating living spaces and meeting places for all city residents

INDI.59 4.3.1 Presence of facilities or services of common interest

INDI.60 4.3.2 Number of days a year marked by a market-type event, show, exhibit, etc.

INDI.61 4.3.3 Proportion of main dwellings in the total housing stock

4.4 Avoid motorised travel and improve transportation infrastructure of low environmental impact (transport, two wheels, on foot)

INDI.62 4.4.1 Length of streets in the district (public transport, pedestrian walkways, bike path) in linear feet per inhabitant

INDI.63 4.4.2 Proportion of journeys made by public transport

INDI.64 4.4.3 Proportion of journeys made on foot or bicycle, depending on the location of the district regarding the city

INDI.65 4.4.4 Length of streets without footpaths or footpaths in disrepair

INDI.66 4.4.5 Municipal or private systems that favour motorised traffic and public transport.

INDI.67 4.4.6 Quality of parking system

\section{STRENGTHEN SOCIAL RELATIONSHIPS}

5.1 Strengthen social cohesion and participation

INDI.68 5.1.1 Percentage of the population participating in sustainable development initiatives in the area (especially in Agenda 21).

INDI.69 5.1.2 Number of built and rehabilitated landscaped public spaces as part of a consultation with residents' buildings.

5.2 Improve solidarity networks and social capital

INDI.70 5.2.1 Percentage of the population participating in community activities and solidarity actions

INDI.71 5.2.2 Presence of activities in the social and solidarity economy field

INDI.72 5.2.3 Presence of integration of economic activities into the area (construction waste, wood, maintenance, etc.)

INDI.73 5.2.4 Presence of North / South solidarity 
Table S1.6 BRIDGE

Code Sustainability dimension/Category/Indicator

ENVIRONMENTAL

\begin{tabular}{|c|c|}
\hline & 1. ENERGY \\
\hline BRDG.1 & Energy consumption by cooling/heating \\
\hline BRDG.2 & Anthropogenic heat \\
\hline BRDG.3 & Bowen ratio \\
\hline \multirow[t]{2}{*}{ BRDG.4 } & Percentage of energy from renewable sources \\
\hline & 2. THERMAL COMFORT \\
\hline BRDG.5 & Thermal comfort index (cooling power) \\
\hline BRDG.6 & Air temperature \\
\hline \multirow[t]{2}{*}{ BRDG.7 } & Number of days above air temperature threshold \\
\hline & 3. WATER \\
\hline BRDG.8 & Water consumption \\
\hline BRDG.9 & Evapotranspiration \\
\hline BRDG.10 & Infiltration \\
\hline BRDG.11 & Surface run-off \\
\hline \multirow[t]{2}{*}{ BRDG.12 } & Potential flood risk \\
\hline & 4. GREENHOUSE GASES \\
\hline \multirow[t]{2}{*}{ BRDG.13 } & Emissions $(\mathrm{CO} 2, \mathrm{CH} 4)$ \\
\hline & 5. AIR QUALITY \\
\hline BRDG.14 & Concentrations (NOx, PM10, PM2.5, O3, CO, SO2) \\
\hline BRDG.15 & Exceedances (NOx, PM10, O3, SO2) \\
\hline BRDG.16 & Potential population exposure (NOx, PM10, O3, SO2) \\
\hline \multicolumn{2}{|l|}{ SOCIAL } \\
\hline & 6. LAND USE \\
\hline BRDG.17 & New urbanized areas \\
\hline BRDG.18 & Brownfields re-used \\
\hline \multirow[t]{2}{*}{ BRDG.19 } & Density of development \\
\hline & 7. MOBILITY/ACCESSIBILITY \\
\hline BRDG.20 & Quality of pedestrian \\
\hline BRDG.21 & Length of cycle-ways provided \\
\hline BRDG.22 & Length of new roads provided \\
\hline BRDG.23 & Percentage of use of public transport \\
\hline \multirow[t]{2}{*}{ BRDG.24 } & Number of inhabitants with access to public transport \\
\hline & 8. SOCIAL INCLUSION \\
\hline BRDG.25 & Number of inhabitants with access to services \\
\hline \multirow[t]{2}{*}{ BRDG.26 } & Number of inhabitants with access to social housing \\
\hline & 9. HUMAN WELL-BEING \\
\hline BRDG.27 & Number of inhabitants affected by flash flooding \\
\hline BRDG.28 & Number of inhabitants affected by heat waves \\
\hline \multirow[t]{4}{*}{ ECONOMI } & \\
\hline & 10. COST OF PROPOSED DEVELOPMENT \\
\hline & 11. EFFECTS ON LOCAL ECONOMY (EMPLOYMENT) \\
\hline & 12. EFFECTS ON LOCAL ECONOMY (REVENUE) \\
\hline
\end{tabular}


Table S1.7 KITCASP

\begin{tabular}{|c|c|}
\hline \multirow[t]{2}{*}{ Code } & \multirow{2}{*}{$\begin{array}{l}\text { Policy Theme/Indicator } \\
\text { 1. ECONOMIC COMPETITIVENESS AND RESILIENCE }\end{array}$} \\
\hline & \\
\hline KIT.1 & GDP per capita/GVA per capita \\
\hline KIT.2 & Employment rate of population aged $20-64$ \\
\hline KIT.3 & Total R \& D expenditure as \% of GDP \\
\hline KIT.4 & Balance of external trade \\
\hline \multirow[t]{2}{*}{ KIT.5 } & Economic structure \\
\hline & 2. INTEGRATED SPATIAL DEVELOPMENT \\
\hline KIT.6 & Population density - Population change \\
\hline KIT.7 & House completions \\
\hline KIT.8 & Modal split \\
\hline KIT.9 & Land use change \\
\hline \multirow[t]{2}{*}{ KIT.10 } & Access to services (hospitals and schools) \\
\hline & 3. SOCIAL COHESION AND QUALITY OF LIFE \\
\hline KIT.11 & Population aged 30-34 with tertiary education \\
\hline KIT.12 & Population at risk of poverty \\
\hline KIT.13 & Green space accessibility \\
\hline KIT.14 & Well-being index \\
\hline \multirow[t]{2}{*}{ KIT.15 } & Dependency ratio \\
\hline & 4. ENVIRONMENTAL RESOURCE MANAGEMENT \\
\hline KIT.16 & Renewable energy production (wind, hydro, biomass, etc.) \\
\hline KIT.17 & Greenhouse gas emissions \\
\hline KIT.18 & Population at risk of flooding (living in flood-prone areas) \\
\hline KIT.19 & Number and status of protected European habitats and species \\
\hline KIT.20 & Water quality status \\
\hline
\end{tabular}


Table S1.8 LB

Code Category/Subcategory/Indicator

1. CITY ENVIRONMENT CRITERIA

1.0. Preserve, maintain and protect the natural capital

LB.1 1.01. Preserve existing (natural and artificial) ecosystems

LB.2 1.02. Respect and integrate into the territory

LB.3 1.03. Connect protected areas

LB.4 1.04. Respect the landscape

LB.5 1.05. Soil conservation (reduce consumption and preserve its productivity)

LB.6 1.06. Prioritise local production

\section{URBAN CONTEXT CRITERIA}

2.0. Define a more sustainable urban structure and model

LB.7 2.01. Complexify land use

LB.8 2.02. Encourage urban compactness (density, constructability, etc.)

LB.9 2.03. Encourage polycentricity

2.1. Promote a more sustainable use of built heritage

LB.10 2.11. Foster intensive and efficient use of built heritage.

LB.11 2.12. Encourage rehabilitation (over new buildings)

LB.12 2.13. Adopt bioclimatic criteria for urban development and building

LB.13 2.14. Encourage diversity of housing types

LB.14 2.15. Complexify uses of buildings

2.2. Promote diversity, quality and versatility of urban public spaces

LB.15 2.21. Remove architectural barriers

LB.16 2.22. Design multifunctional legible spaces

LB.17 2.23. Apply bioclimatic criteria to open spaces

LB.18 2.24. Incorporate multipurpose street furniture

LB.19 2.25. Reduce typologies that favour privatisation of open spaces

2.3. Promote access to nature (green areas)

LB.20 2.31. Define a minimum size of green areas (per person, home, etc.)

LB.21 2.32. Define criteria of the shape and minimum size of green areas

LB.22 2.33. Promote biodiversity

LB.23 2.34. Introduce green networks on the neighbourhood and city scales

LB.24 2.35. Promote citizens' access to green areas

LB.25 2.36. Incorporate vegetation into public spaces

LB.26 2.37. Connect ecologically different green areas

\subsection{Improve access to facilities}

LB.27 2.41. Define an adequate supply of public facilities and services

LB.28 2.42. Foster proximity to amenities and facilities

\section{TRANSPORTATION ISSUES CRITERIA}

\subsection{Reduce distances}

LB.29 3.01. Associate home and jobs

LB.30 3.02. Establish logistics distribution platforms in each neighbourhood

LB.31 3.03. Reserve spaces for marketing local products

LB.32 3.04. Reduce the infrastructure needed for the city to operate

\subsection{Enhance non-motorised transportation}

LB.33 3.11. Integrate pedestrian and cycling networks with green areas

LB.34 3.12. Enlarge pedestrian areas

LB.35 3.13. Build pedestrian and cycling networks in the neighbourhood

LB.36 3.14. Provide bicycle parking

LB.37 3.15. Integrate cycling with public transport

3.2. Reduce private motorised traffic by strengthening public transport

LB.38 3.21. Establish an adequate supply of public transport on the urban scale

LB.39 3.22. Build integrated public transport networks

LB.40 3.23. Reduce the speed of private motorised traffic

LB.41 3.24. Reduce the area used by private vehicles

LB.42 3.25. Restrict the use of private vehicles

LB.43 3.26. Restrict parking spaces for private vehicles

4.0. Optimise and reduce energy consumption 
LB.44 4.01. Encourage savings and promote energy efficiency

LB.45 4.02. Adapt urban morphology to bioclimatic conditions

LB.46 4.03. Harness sunlight and wind benefits in buildings and outdoor spaces

LB.47 4.04. Make urban structures compatible with centralised heating systems

LB.48 4.05. Encourage the use of renewable energy

LB.49 4.06. Encourage local energy production

4.1. Optimise and reduce water consumption

LB.50 4.11. Reduce losses in distribution networks

LB.51 4.12. Encourage building types with lower water demands

LB.52 4.13. Foster efficient irrigation systems

LB.53 4.14. Encourage rainwater harvesting in buildings

LB.54 4.15. Use systems to retain and filter stormwater

LB.55 4.16. Treat and recover natural watercourses

LB.56 4.17. Encourage the use of permeable paving

4.2. Minimise the impact of construction materials

LB.57 4.21. Reduce earthmoving works

LB.58 4.22. Encourage the use of local materials

LB.59 4.23. Use building techniques that facilitate reuse

LB.60 4.24. Foster the use of easily recyclable materials

LB.61 4.25. Encourage sharing service networks

\begin{tabular}{|c|c|}
\hline & 5. WASTE CRITERIA \\
\hline & 5.0. Reduce waste \\
\hline LB. 62 & 5.01. Foster selective collection and separate sewer systems \\
\hline LB.63 & 5.02. Users' proximity to collection systems \\
\hline LB.64 & 5.03. Promote reserves for composting and vegetable waste \\
\hline LB. 65 & 5.04. Use systems to reuse wastewater \\
\hline \multirow[t]{2}{*}{ LB.66 } & 5.05. Encourage recycling and reuse \\
\hline & 5.1. Manage waste to reduce its impact \\
\hline LB.67 & 5.11. Make hazardous waste treatment compulsory \\
\hline LB.68 & 5.12. Manage the waste generated by construction and demolition \\
\hline LB.69 & 5.13. Construct debugging systems with a non-aggressive environment \\
\hline \multirow[t]{3}{*}{ LB.70 } & 5.14. Reduce emissions and pollutant discharge \\
\hline & 6. SOCIAL COHESION ISSUES CRITERIA \\
\hline & 6.0. Promote social cohesion and prevent exclusion \\
\hline LB.71 & 6.01. Promote citizens associations \\
\hline LB.72 & 6.02. Reserve spaces for non-profit organisations \\
\hline LB.73 & 6.03. Foster social complexity \\
\hline LB.74 & 6.04. Encourage citizens identify themselves with their environment (cultural heritage) \\
\hline \multirow[t]{2}{*}{ LB.75 } & 6.05. Promote access to affordable housing \\
\hline & 6.1. Complexity of the social fabric \\
\hline LB.76 & 6.11. Encourage a mixed use in the neighbourhood \\
\hline LB.77 & 6.12. Improve supply and access to services and facilities in the neighbourhood \\
\hline LB.78 & 6.13. Encourage an economic exchange with the rural world \\
\hline LB.79 & 6.14. Promote a minimum percentage of local activities \\
\hline \multirow[t]{3}{*}{ LB. 80} & 6.15. Encourage activities that promote diversity of use \\
\hline & 7. GOVERNMENTAL ISSUES CRITERIA \\
\hline & 7.0. Enhance administrative transparency \\
\hline LB.81 & 7.01. Provide access to information (including technical data and reports) \\
\hline LB. 82 & 7.02. Provide channels for information to flow in both directions \\
\hline \multirow[t]{2}{*}{ LB.83 } & 7.03. Establish procedures for cooperation between administrations \\
\hline & 7.1. Favour citizens' training and education \\
\hline LB.84 & 7.11. Make and provide specific educational materials \\
\hline LB. 85 & 7.12. Develop courses and run workshops and debates on urban planning \\
\hline LB.86 & 7.13. Promote environmental education and awareness \\
\hline \multirow[t]{2}{*}{ LB. 87} & 7.14. Support the implementation of Agenda 21 \\
\hline & 7.2. Integrate participation in planning \\
\hline LB. 88 & 7.21. In the diagnosis process \\
\hline LB.89 & 7.22. In strategic decision making \\
\hline LB.90 & 7.23. While drafting the urban plan \\
\hline LB.91 & 7.24. While approving the urban plan \\
\hline
\end{tabular}


LB.93 7.26. During the integration of Agenda 21 into urban planning 
Table S1.9 SMIS

\begin{tabular}{|c|c|}
\hline \multirow[t]{3}{*}{ Code } & \multirow{2}{*}{$\begin{array}{l}\text { Are/Category/Indicator } \\
\text { 1. LAND OCCUPATION }\end{array}$} \\
\hline & \\
\hline & 01. Occupation of land use \\
\hline SMIS.1 & 01.1 Artificial surface per capita \\
\hline SMIS.2 & 01.2 Artificial surface in relation to the municipal surface \\
\hline \multirow[t]{2}{*}{ SMIS.3 } & 01.3 Urbanized area of the municipality \\
\hline & 02. Population density \\
\hline SMIS.4 & 02.1 Density of housing \\
\hline \multirow[t]{2}{*}{ SMIS.5 } & 02.2 Density of floating and diverse population \\
\hline & 03. Urban compactness \\
\hline \multirow[t]{2}{*}{ SMIS.6 } & 03.1 Dispersion of population centres \\
\hline & 04. Green areas per capita \\
\hline \multirow[t]{3}{*}{ SMIS.7 } & 04.1 Public green areas and present in the urban planning \\
\hline & 2. URBAN COMPLEXITY \\
\hline & 05. Urban complexity \\
\hline SMIS.8 & 05.1 Number of activities per inhabitant \\
\hline \multirow[t]{3}{*}{ SMIS.9 } & 06. Balance between employment and residence \\
\hline & 3. SUSTAINABLE MOBILITY \\
\hline & 07. Modal distribution of the transport system \\
\hline SMIS.10 & 07.1 Modal transport intermunicipal \\
\hline \multirow[t]{2}{*}{ SMIS.11 } & 07.2 Time and average distance travelled by reason of commuting \\
\hline & 08. Road space for pedestrians \\
\hline \multirow[t]{2}{*}{ SMIS.12 } & 08.1 Proportion of the number of streets with priority for pedestrians \\
\hline & 09. Space for bicycles \\
\hline \multirow[t]{2}{*}{ SMIS.13 } & 09.1 Proximity of the population to cycling network \\
\hline & 10. Road space for public transport \\
\hline SMIS.14 & 10.1 Proximity of the population to public transport network \\
\hline \multirow[t]{3}{*}{ SMIS.15 } & 10.2 Number of intercity services by urban center \\
\hline & 4. URBAN METABOLISM \\
\hline & 11. Urban water consumption \\
\hline \multirow[t]{2}{*}{ SMIS.16 } & 11.1 Water losses in the distribution network \\
\hline & 12. Treatment of urban waste water \\
\hline \multirow[t]{2}{*}{ SMIS.17 } & 12.1 Percentage of population connected to sewage networks \\
\hline & 13. Reuse of treated wastewater \\
\hline \multirow[t]{2}{*}{ SMIS.18 } & 13.1 Volume of recycled water per capita \\
\hline & 14. Final energy consumption \\
\hline \multirow[t]{2}{*}{ SMIS.19 } & 14.1 Municipal Power Consumption \\
\hline & 15. Local production of renewable energy \\
\hline SMIS.20 & 15.1 Local energy self-sufficiency from renewable energies \\
\hline SMIS.21 & 16. Generation of municipal solid waste \\
\hline SMIS.22 & 17. Selective collection of waste \\
\hline \multirow[t]{2}{*}{ SMIS.23 } & 18. Emissions of $\mathrm{CO}_{2}$ equivalent \\
\hline & 19. Quality of air \\
\hline SMIS.24 & 19.1 Population exposed to levels of immission lower than $40 \mu \mathrm{g} / \mathrm{m} 3$ \\
\hline \multirow[t]{3}{*}{ SMIS.25 } & 20. Acoustic comfort \\
\hline & 5. SOCIAL COHESION \\
\hline & 21. Ageing of the population \\
\hline \multirow[t]{2}{*}{ SMIS.26 } & 21.1 Segregation index for older people \\
\hline & 22. Foreign population \\
\hline SMIS.27 & 22.1 Segregation index of the foreign population \\
\hline \multirow[t]{2}{*}{ SMIS.28 } & 22.2 Foreign population by origin \\
\hline & 23. Number of graduates \\
\hline SMIS.29 & 23.1 Segregation index of the population with higher education \\
\hline & 24. Workforce \\
\hline SMIS.30 & 24.1 Unemployment rate \\
\hline SMIS.31 & 24.2 Dependency rate \\
\hline & 25. Self-containment labour \\
\hline SMIS.32 & 25.1 Self-sufficiency employment \\
\hline
\end{tabular}




\section{Proximity to basic urban services}

SMIS.34 26.1 Time of population access to basic urban services

SMIS.35 26.2 Access to ICT

SMIS.36 27. Citizen satisfaction with the local community

28. Association rate

SMIS.37

28.1 Associated population

\section{BIODIVERSITY INCREASEMENT}

29. Landscape area recovered

SMIS.38

29.1 Municipal Investment in restoration projects and environmental conservation

SMIS.39

30. Agricultural land and ecological farming 
Table S1.10 CGYM

\begin{tabular}{|c|c|}
\hline Code & Area/Sub-area/Indicator \\
\hline & 1. LAND OCCUPATION \\
\hline & 1.1 Intensity of use \\
\hline CGYM.1 & 1.1.1 Density of housing \\
\hline \multirow[t]{3}{*}{ CGYM.2 } & 1.1.2 Absolut compactness \\
\hline & 2. PUBLIC SPACE AND LIVING \\
\hline & 2.1 Public space \\
\hline \multirow[t]{2}{*}{ CGYM.3 } & 2.1.1 Corrected compactness \\
\hline & 2.1 Livability of urban space \\
\hline CGYM.4 & 2.2.1 Air quality \\
\hline CGYM.5 & 2.2.2 Acoustic comfort \\
\hline CGYM.6 & 2.2.3 Thermal comfort \\
\hline CGYM.7 & 2.2.4 Road accessibility \\
\hline CGYM.8 & 2.2.5 Proportion of the street \\
\hline CGYM.9 & 2.2.6 Perception of urban green space \\
\hline \multirow[t]{3}{*}{ CGYM.10 } & 2.2.7 Proximity of the population to basic services \\
\hline & 3. MOBILITY AND FACILITIES \\
\hline & 3.1 Network configuration \\
\hline CGYM.11 & 3.1.1 Travel mode of population \\
\hline \multirow[t]{2}{*}{ CGYM.12 } & 3.1.2 Proximity of the population public transport networks and alternatives to the car. \\
\hline & 3.2 Functionality \\
\hline CGYM.13 & 3.2.1 Distribution of public road: pedestrian road - vehicular road \\
\hline \multirow[t]{2}{*}{ CGYM.14 } & 3.2.2 Proximity of the population to bicycle parking \\
\hline & 3.3 Infrastructure \\
\hline CGYM.15 & 3.3.1 Parking for private vehicles off the road \\
\hline CGYM.16 & 3.3.2 Theoretical infrastructure deficit of parking for private vehicles \\
\hline CGYM.17 & 3.3.3 Loading and unloading of goods out of the driveway \\
\hline \multirow[t]{3}{*}{ CGYM.18 } & 3.3.4 Infrastructure services \\
\hline & 4. URBAN COMPLEXITY \\
\hline & 4.1 Diversity \\
\hline CGYM.19 & 4.1.1 Urban diversity index \\
\hline CGYM.20 & 4.1.2 Balance between employment and residence \\
\hline CGYM.21 & 4.1.3 Proximity to daily business activities \\
\hline \multirow[t]{2}{*}{ CGYM.22 } & 4.1.4 Dense knowledge activities \\
\hline & 4.2 Functionality \\
\hline \multirow[t]{3}{*}{ CGYM.23 } & 4.2.1 Spatial and functional continuity of the street corridor \\
\hline & 5. GREEN SPACES AND BIODIVERSITY \\
\hline & 5.1 Structure \\
\hline CGYM.24 & 5.1.1 Soil biotic index \\
\hline CGYM.25 & 5.1.2 Green space per inhabitant \\
\hline CGYM.26 & 5.1.3 Green roofs \\
\hline CGYM.27 & 5.1.4 Proximity of the population to green spaces \\
\hline CGYM.28 & 5.1.5 Biodiversity of trees \\
\hline \multirow[t]{2}{*}{ CGYM.29 } & 5.1.6 Connectivity of urban green corridors \\
\hline & 5.2 Potential \\
\hline \multirow[t]{4}{*}{ CGYM.30 } & 5.2.1 Functionality index of urban parks \\
\hline & 6. URBAN METABOLISM \\
\hline & 6.1 Energy \\
\hline & 6.1.1 Energy consumption by sector (COe) (for consolidated urban fabric) \\
\hline CGYM.31 & Energy demand by sector (for new urban developments) \\
\hline CGYM.32 & 6.1.2 Local production of renewable energy \\
\hline \multirow[t]{3}{*}{ CGYM.33 } & 6.1.3 Energy self-sufficiency from renewable energies \\
\hline & 6.2 Water \\
\hline & 6.2.1 Water consumption by sector (COh) (for consolidated urban fabric) \\
\hline CGYM.34 & Water demand by sector (for new urban development) \\
\hline CGYM.35 & 6.2.2 Regeneration of marginal water \\
\hline \multirow[t]{2}{*}{ CGYM.36 } & 6.2.3 Water self-sufficiency \\
\hline & 6.3 Food \\
\hline
\end{tabular}




\subsection{Waste and materials}

CGYM.38 6.4.1 Valorisation of construction and demolition waste

CGYM.39 6.4.2 Selective collection of waste

CGYM.40 6.4.3 Provision of recycling containers

CGYM.41 6.4.4 Proximity of the population to collection waste points

CGYM.42 6.4.5 Proximity of the population to collection waste centres

CGYM.43 6.4.6 Closing the cycle of organic matter

\subsection{Atmosphere}

CGYM.44 6.5.1 Emission of greenhouse gases in the atmosphere

CGYM.45 6.5.2 Light pollution

\begin{tabular}{ll}
\hline & 7. SOCIAL COHESION \\
\hline CGYM.46 & 7.1 Mixed population \\
\hline CGYM.47 & 7.1.2 Foreign population \\
CGYM.48 & 7.1.3 Number of graduates \\
& 7.2 Access to affordable housing \\
\hline CGYM.49 & 7.2.1 Social housing \\
\hline & 7.3 Public equipment \\
\hline CGYM.50 & 7.3.1 Provision of public equipment and facilities \\
CGYM.51 & 7.3.2 Proximity of the population to public facilities \\
\hline & SUSTAINABILITY FUNCTION \\
\hline CGYM.52 & 8.1 Efficiency of the urban system
\end{tabular}


Table S1.11 SEV

Code Category/Indicator

\begin{tabular}{|c|c|}
\hline & 1. URBAN MORPHOLOGY \\
\hline SEV.1 & 1.1. Building density \\
\hline SEV. 2 & 1.2. Absolut compactness \\
\hline SEV.3 & 1.3. Corrected compactness \\
\hline & 2. PUBLIC SPACE AND MOBILITY \\
\hline SEV.4 & 2.1 Surface of public road for automobile traffic and public transport. \\
\hline SEV.5 & 2.2 Public road for pedestrians and other uses of public space \\
\hline SEV.6 & 2.3 Continuity of street corridor \\
\hline SEV.7 & 2.4 Prohibition of residential gated condominiums \\
\hline SEV.8 & 2.5 Provision of trees according to the vertical projection of shadow on ground \\
\hline SEV.9 & 2.6 Thermal potential habitability in urban spaces \\
\hline SEV.10 & 2.7 Provision of lamps in public lighting without light pollution. \\
\hline SEV.11 & 2.8 Design and introduction of ICT in the public space \\
\hline SEV.12 & 2.9 Accessibility to stops of public network transport. \\
\hline SEV.13 & 2.10 Accessibility to the bicycle network. \\
\hline SEV.14 & 2.11 Accessibility to underground logistics platforms \\
\hline SEV.15 & 2.12 Reserve for parking spaces: private vehicles \\
\hline SEV.16 & 2.13 Underground tunnels for facilities \\
\hline SEV.17 & 2.14 Reserve for parking spaces: Bike \\
\hline SEV.18 & 2.15 Accessibility for disabled citizens \\
\hline & 3. COMPLEXITY \\
\hline SEV.19 & 3.1 Urban complexity $(\mathrm{H})$ \\
\hline SEV.20 & 3.2 Balance between employment and residence \\
\hline SEV.21 & 3.3 Minimum surface of shops \\
\hline SEV.22 & 3.4 Proportion of daily activities \\
\hline SEV.23 & 3.5 Diversity of activities. Specialization Index \\
\hline SEV.24 & 3.6 Proportion of dense knowledge activities. Activities @ \\
\hline & 4. URBAN METABOLISM \\
\hline SEV.25 & 4.1 Energy self-generation households \\
\hline SEV.26 & 4.2 Water self-sufficiency in urban demand \\
\hline SEV.27 & 4.3 Minimizing collection systems in public spaces. Solid Waste \\
\hline SEV.28 & 4.4 Reduction and valorisation of construction and demolition waste \\
\hline SEV.29 & 4.5 Use of reused, recycled and renewable materials \\
\hline SEV.30 & 4.6 Reserve spaces for self-composting processes and urban gardens \\
\hline SEV.31 & 4.7 Reserve space for the installation of clean points \\
\hline SEV.32 & 4.8 Noise level \\
\hline & 5. BIODIVERSITY \\
\hline SEV.33 & 5.1 Citizens' access to green space \\
\hline SEV.34 & 5.2 Compensation waterproofing and sealing: permeability index \\
\hline SEV.35 & 5.3 Provision of trees in public space \\
\hline SEV.36 & 5.4 Green corridors \\
\hline SEV.37 & 5.5 A second layer of biodiversity in height: green roofs \\
\hline SEV.38 & 5.6 A second layer of biodiversity in height: green facades \\
\hline SEV.39 & 5.7 Reserve of free space in block interiors \\
\hline SEV.40 & 5.8 Corrected weighted compactness \\
\hline SEV.41 & 5.9 Requirements spaces for staying \\
\hline & 6. SOCIAL COHESION \\
\hline SEV.42 & 6.1 Access to basic facilities and services \\
\hline SEV.43 & 6.2 Mix rents in residential building: social housing \\
\hline & 7. SUSTAINABILITY \\
\hline
\end{tabular}


Table S1.12 BCN

Code Category/Indicator

\begin{tabular}{|c|c|}
\hline & 1. TERRITORY \\
\hline BCN.1 & 1.1 Urban land use \\
\hline \multirow[t]{2}{*}{$\mathrm{BCN} .2$} & 1.2 Protection of areas with natural interest \\
\hline & 2. WASTE \\
\hline BCN.3 & 2.1 Intensity of waste production of the local economy \\
\hline BCN.4 & 2.2 Recovery of municipal waste \\
\hline BCN.5 & 2.3 Use of municipal clean points of recycling \\
\hline \multirow[t]{2}{*}{ BCN.6 } & 2.4 Recovery of industrial waste \\
\hline & 3. ENERGY \\
\hline BCN.7 & 3.1 Local energy intensity \\
\hline BCN.8 & 3.2 Final energy consumption \\
\hline BCN.9 & 3.3Urban structure: population mobility \\
\hline BCN.10 & 3.4 Production of renewable energies \\
\hline \multirow[t]{2}{*}{ BCN.11 } & 3.5 Greenhouse gases emissions \\
\hline & 4. WATER \\
\hline BCN.12 & 4.1 Intensity of water consumption of the local economy \\
\hline BCN.13 & 4.2 Municipal water supply \\
\hline
\end{tabular}


Table S1.13 BIL

\begin{tabular}{|c|c|}
\hline Code & Category/Indicator \\
\hline & 1. WATER \\
\hline BIL.1 & 1. Water consumption \\
\hline BIL.2 & 2. Water discharges \\
\hline & 2. ENERGY \\
\hline BIL.3 & 3. Energy consumption \\
\hline BIL.4 & 4. Production and consumption of renewable energy \\
\hline & 3. TRANSPORT \\
\hline BIL.5 & 5. Local mobility and passenger transport \\
\hline BIL.6 & 6. Intensity of network traffic access to Bilbao \\
\hline BIL.7 & 7. Distribution of length of track devoted to transport infrastructure \\
\hline BIL.8 & 8. Mobile vehicles \\
\hline BIL.9 & 9. Motorisation index \\
\hline BIL.10 & 10. Road safety \\
\hline & 4. AIR \\
\hline BIL.11 & 11. Urban air quality \\
\hline & 5. NOISE \\
\hline BIL.12 & 12. Urban noise \\
\hline & 6. NATURAL ENVIRONMENT, BIODIVERSITY AND GREEN AREAS \\
\hline BIL.13 & 13. Green areas and open spaces per inhabitant \\
\hline BIL.14 & 14. Reintroduction of native tree species \\
\hline BIL.15 & 15. Municipal spending on environment \\
\hline & 7. SOIL \\
\hline BIL.16 & 16. Sustainable land use \\
\hline & 8. WASTE \\
\hline BIL.17 & 17. Generation and waste management \\
\hline & 9. URBAN SPACE \\
\hline BIL.18 & 18. Availability of public open areas and services in the municipality \\
\hline BIL.19 & 19. Number of social housing completed annually \\
\hline BIL.20 & 20. Restoration of urban surfaces \\
\hline & 10. ECONOMIC ACTIVITIES \\
\hline BIL.21 & 21. Dynamism of the local economy \\
\hline BIL.22 & 22. Integrating environment in the activities of the municipality \\
\hline BIL.23 & 23. Registered unemployment rate \\
\hline BIL.24 & 24. Tourist vitality \\
\hline & 11. SOCIETY \\
\hline BIL.25 & 25. Poverty and social exclusion \\
\hline BIL.26 & 26. Citizen satisfaction with the local community \\
\hline BIL.27 & 27. Index of children / youth / aging / dependency population \\
\hline BIL.28 & 28. Municipal spending on social policies \\
\hline BIL.29 & 29. Municipal Implementation in international solidarity activities \\
\hline BIL.30 & 30. Integration of immigrants \\
\hline BIL.31 & 31. Knowledge of Basque language \\
\hline BIL.32 & 32. Municipal spending in organizing cultural activities \\
\hline & 12. INFORMATION, AWARENESS AND CITIZEN PARTICIPATION \\
\hline BIL.33 & 33. Citizen participation \\
\hline BIL.34 & 34. Environmental education \\
\hline
\end{tabular}


Supplementary Information 2: Classification of the indicators into the 14 categories and 69 subcategories

This information presents a classification of the 786 indicators provided by the 13 tools in the proposed two-level structure, which has been divided into 14 categories and 69 subcategories.

Table S2.1. Classification of indicators in category "site and soil"

\begin{tabular}{|c|c|c|c|c|c|c|c|c|c|c|c|c|c|}
\hline \multirow[b]{2}{*}{ Subcategories } & \multicolumn{13}{|c|}{ Tools } \\
\hline & LEED ND & $\begin{array}{l}\text { BREEA } \\
\text { M } \\
\text { Comm }\end{array}$ & CASBEE UD & ECOCITY & $\begin{array}{l}\text { INDI-RU } \\
2005\end{array}$ & BRIDGE & KITCASP & LB & SMIS & CGYM & SEV & $\mathrm{BCN}$ & BIL \\
\hline \multirow{5}{*}{$\begin{array}{l}\text { Weather and site } \\
\text { conditions }\end{array}$} & LEED. 5 & BRE.1 & CASBEE. 5 & ECO.13 & & BRDG.12 & KIT.18 & LB. 2 & & & & & \\
\hline & LEED. 6 & BRE. 2 & CASBEE. 6 & ECO.14 & & BRDG.27 & & LB. 57 & & & & & \\
\hline & LEED.11 & & CASBEE. 25 & & & BRDG.28 & & & & & & & \\
\hline & & & & & & BRDG.10 & & & & & & & \\
\hline & & BRE.21 & CASBEE. 45 & & & BRDG.11 & & & & & & & \\
\hline \multirow[t]{5}{*}{ Land occupation } & LEED.1 & BRE.18 & & ECO.19 & INDI.17 & BRDG.17 & KIT.9 & & SMIS.1 & & & BCN.1 & \\
\hline & & & & ECO.30 & INDI.26 & & & & SMIS.2 & & & & \\
\hline & & & & & INDI.61 & & & & SMIS.3 & & & & \\
\hline & & & & & & & & & SMIS.4 & & & & \\
\hline & & & & & & & & & SMIS.5 & & & & \\
\hline \multirow{4}{*}{$\begin{array}{l}\text { Soil and heritage } \\
\text { reuse and } \\
\text { conservation }\end{array}$} & LEED.7 & BRE.19 & CASBEE.34 & ECO. 2 & INDI.16 & BRDG.18 & & LB. 5 & & & & BCN.2 & BIL.16 \\
\hline & LEED.41 & BRE.20 & & ECO.26 & INDI.20 & & & LB.10 & & & & & BIL.20 \\
\hline & LEED.42 & & & ECO.27 & INDI.58 & & & LB.11 & & & & & \\
\hline & LEED.43 & & & ECO.29 & & & & LB.74 & & & & & \\
\hline \multirow[t]{6}{*}{ Compactness } & LEED.16 & & & ECO.28 & INDI.14 & BRDG.19 & & LB. 8 & SMIS.6 & CGYM.1 & SEV.1 & & \\
\hline & LEED.19 & & & ECO.31 & & & & & & CGYM.2 & SEV. 2 & & \\
\hline & & & & ECO.34 & & & & & & & & & \\
\hline & & & & ECO. 148 & & & & & & & & & \\
\hline & & & & ECO.179 & & & & & & & & & \\
\hline & & & & ECO.183 & & & & & & & & & \\
\hline
\end{tabular}


Table S2.2. Classification of indicators in category "urban morphology"

\begin{tabular}{|c|c|c|c|c|c|c|c|c|c|c|c|c|c|}
\hline \multirow[b]{2}{*}{ Subcategories } & \multicolumn{13}{|c|}{ Tools } \\
\hline & LEED ND & $\begin{array}{l}\text { BREEA } \\
\mathrm{M} \\
\text { Comm }\end{array}$ & CASBEE UD & ECOCITY & $\begin{array}{l}\text { INDI-RU } \\
2005\end{array}$ & BRIDGE & KITCASP & LB & SMIS & CGYM & SEV & $\mathrm{BCN}$ & BIL \\
\hline \multirow{12}{*}{$\begin{array}{l}\text { Design and quality of } \\
\text { public space }\end{array}$} & LEED.15 & BRE.10 & CASBEE.35 & ECO.18 & INDI.15 & & & LB. 4 & & CGYM.3 & SEV.3 & & \\
\hline & LEED.18 & BRE.26 & CASBEE.38 & ECO.35 & INDI.22 & & & LB.16 & & CGYM.8 & SEV.4 & & \\
\hline & LEED. 22 & BRE.27 & CASBEE.39 & ECO.44 & INDI.23 & & & LB.18 & & CGYM.17 & SEV. 5 & & \\
\hline & LEED. 23 & BRE.28 & & ECO.45 & INDI.24 & & & LB.19 & & CGYM.18 & SEV.7 & & \\
\hline & & BRE.29 & & ECO.46 & INDI.67 & & & & & CGYM.23 & SEV.14 & & \\
\hline & & BRE.30 & & ECO.48 & & & & & & & SEV.16 & & \\
\hline & & BRE.31 & & ECO.49 & & & & & & & SEV.6 & & \\
\hline & & BRE.45 & & ECO.50 & & & & & & & SEV.40 & & \\
\hline & & & & ECO.56 & & & & & & & SEV.41 & & \\
\hline & & & & ECO.76 & & & & & & & & & \\
\hline & & & & ECO.100 & & & & & & & & & \\
\hline & & & & ECO.139 & & & & & & & & & \\
\hline \multirow{9}{*}{$\begin{array}{l}\text { Mixed-used } \\
\text { development }\end{array}$} & LEED.20 & & & ECO.15 & INDI.48 & & & LB.7 & SMIS.9 & CGYM.20 & SEV.20 & & \\
\hline & & & & ECO.16 & INDI.60 & & & LB.14 & SMIS.8 & & SEV.19 & & \\
\hline & & & & ECO.36 & & & & LB.76 & & & SEV.21 & & \\
\hline & & & & ECO.39 & & & & LB. 80 & & & SEV.23 & & \\
\hline & & & & ECO.41 & & & & & & & SEV.42 & & \\
\hline & & & & ECO.42 & & & & & & & & & \\
\hline & & & & ECO.43 & & & & & & & & & \\
\hline & & & & ECO.78 & & & & & & & & & \\
\hline & & & & ECO.167 & & & & & & & & & \\
\hline \multirow[t]{3}{*}{ Equipment } & LEED.26 & & & ECO.37 & INDI.31 & & & LB. 27 & & CGYM.50 & SEV.22 & & BIL.18 \\
\hline & LEED. 27 & & & ECO.175 & INDI.59 & & & LB.77 & & & & & \\
\hline & LEED. 28 & & & & & & & LB.79 & & & & & \\
\hline \multirow{3}{*}{$\begin{array}{l}\text { Universal design and } \\
\text { architectural barriers }\end{array}$} & LEED. 28 & BRE.47 & CASBEE. 32 & ECO.47 & INDI.27 & & & LB. 15 & & CGYM.7 & SEV.18 & & \\
\hline & & & & ECO.75 & & & & & & & & & \\
\hline & & & & ECO.86 & & & & & & & & & \\
\hline \multirow[t]{3}{*}{ Parking space } & & BRE.40 & & ECO.103 & & & & LB.43 & & CGYM.15 & SEV.15 & & \\
\hline & & BRE.41 & & ECO.105 & & & & LB.41 & & CGYM.16 & & & \\
\hline & & & & ECO.106 & & & & & & & & & \\
\hline \multirow{7}{*}{$\begin{array}{l}\text { Safety, health and } \\
\text { hygiene }\end{array}$} & & BRE.22 & CASBEE.26 & ECO.51 & INDI.28 & & & & & & & & \\
\hline & & & CASBEE. 27 & ECO.63 & INDI.29 & & & & & & & & \\
\hline & & & CASBEE.28 & ECO.85 & INDI.30 & & & & & & & & \\
\hline & & & & & INDI.32 & & & & & & & & \\
\hline & & & & & INDI.33 & & & & & & & & \\
\hline & & & & & INDI.34 & & & & & & & & \\
\hline & & & & & INDI.35 & & & & & & & & \\
\hline
\end{tabular}


Table S2.3. Classification of indicators in category "mobility and transport"

\begin{tabular}{|c|c|c|c|c|c|c|c|c|c|c|c|c|c|}
\hline \multirow[b]{2}{*}{ Subcategories } & \multicolumn{13}{|c|}{ Tools } \\
\hline & LEED ND & $\begin{array}{l}\text { BREEA } \\
\mathrm{M} \\
\text { Comm }\end{array}$ & CASBEE UD & ECOCITY & $\begin{array}{l}\text { INDI-RU } \\
2005\end{array}$ & BRIDGE & KITCASP & LB & SMIS & CGYM & SEV & $\mathrm{BCN}$ & $\mathrm{BIL}$ \\
\hline \multirow{11}{*}{$\begin{array}{l}\text { Distances } \\
\text { reduction and } \\
\text { private vehicle use }\end{array}$} & LEED. 8 & BRE.32 & CASBEE.24 & ECO.40 & INDI.49 & BRDG.20 & KIT.10 & LB. 28 & SMIS.12 & CGYM.10 & & BCN.9 & BIL.8 \\
\hline & LEED.10 & BRE.36 & CASBEE.29 & ECO.79 & INDI.56 & BRDG.22 & & LB. 29 & SMIS.34 & CGYM.12 & & & BIL.9 \\
\hline & LEED. 24 & BRE.39 & CASBEE.30 & ECO.80 & INDI.62 & & & LB. 30 & & CGYM.13 & & & \\
\hline & & BRE.42 & CASBEE.31 & ECO.81 & INDI.64 & & & LB.33 & & CGYM.21 & & & \\
\hline & & & CASBEE.65 & ECO.87 & INDI.65 & & & LB.34 & & CGYM.51 & & & \\
\hline & & & & ECO.97 & & & & LB. 35 & & & & & \\
\hline & & & & ECO.98 & & & & LB.40 & & & & & \\
\hline & & & & ECO.99 & & & & LB.42 & & & & & \\
\hline & & & & ECO.102 & & & & & & & & & \\
\hline & & & & ECO.164 & & & & & & & & & \\
\hline & & & & ECO.165 & & & & & & & & & \\
\hline \multirow{9}{*}{$\begin{array}{l}\text { Public transport } \\
\text { and other } \\
\text { sustainable } \\
\text { alternatives }\end{array}$} & LEED.17 & BRE.33 & & ECO.17 & INDI.63 & BRDG.21 & KIT.8 & LB.36 & SMIS.13 & CGYM.11 & SEV.13 & & BIL.5 \\
\hline & LEED.9 & BRE.34 & & ECO.33 & INDI.66 & BRDG.23 & & LB. 37 & SMIS.14 & CGYM.14 & SEV.12 & & BIL.7 \\
\hline & & BRE.35 & & ECO.82 & & BRDG.24 & & LB.38 & SMIS.15 & & SEV.17 & & \\
\hline & & BRE.37 & & ECO.83 & & & & LB.39 & & & & & \\
\hline & & BRE.38 & & ECO.84 & & & & & & & & & \\
\hline & & BRE.43 & & ECO.88 & & & & & & & & & \\
\hline & & & & ECO.89 & & & & & & & & & \\
\hline & & & & ECO.90 & & & & & & & & & \\
\hline & & & & ECO.91 & & & & & & & & & \\
\hline \multirow{2}{*}{$\begin{array}{l}\text { Efficiency of } \\
\text { public transport }\end{array}$} & LEED. 25 & BRE.44 & & ECO.95 & & & & & & & & & \\
\hline & & & & ECO.101 & & & & & & & & & \\
\hline \multirow{7}{*}{$\begin{array}{l}\text { Transport } \\
\text { management }\end{array}$} & & BRE.46 & CASBEE.23 & ECO.92 & & & & LB. 32 & SMIS.10 & & SEV.11 & & BIL.6 \\
\hline & & & CASBEE.66 & ECO.93 & & & & & SMIS.11 & & & & BIL.10 \\
\hline & & & CASBEE. 72 & ECO.94 & & & & & & & & & \\
\hline & & & CASBEE.79 & ECO.107 & & & & & & & & & \\
\hline & & & CASBEE. 80 & ECO.109 & & & & & & & & & \\
\hline & & & & ECO.110 & & & & & & & & & \\
\hline & & & & ECO.113 & & & & & & & & & \\
\hline
\end{tabular}


Table S2.4. Classification of indicators in category "nature and biodiversity"

\begin{tabular}{|c|c|c|c|c|c|c|c|c|c|c|c|c|c|}
\hline \multirow[b]{2}{*}{ Subcategories } & \multicolumn{13}{|c|}{ Tools } \\
\hline & $\begin{array}{l}\text { BREEAM } \\
\text { Communi } \\
\text { ties }\end{array}$ & $\begin{array}{l}\text { BREEA } \\
\text { M } \\
\text { Comm. }\end{array}$ & CASBEE UD & ECOCITY & $\begin{array}{l}\text { INDI- } \\
\text { RU } \\
2005\end{array}$ & BRDG & KITCASP & LB & SMIS & CGYM & SEV & $\mathrm{BCN}$ & BIL \\
\hline \multirow[t]{8}{*}{ Green areas } & & BRE.23 & CASBEE.13 & ECO.1 & INDI.21 & & KIT.13 & LB. 3 & SMIS.7 & CGYM.9 & SEV.34 & & BIL.13 \\
\hline & & BRE.54 & & ECO.3 & & & & LB. 20 & & CGYM. 25 & SEV.35 & & \\
\hline & & & & ECO.6 & & & & LB. 21 & & CGYM.26 & SEV.36 & & \\
\hline & & & & ECO.7 & & & & LB. 23 & & CGYM.27 & SEV.33 & & \\
\hline & & & & ECO.52 & & & & LB. 24 & & CGYM.29 & SEV.37 & & \\
\hline & & & & ECO.58 & & & & LB. 25 & & CGYM.30 & SEV.38 & & \\
\hline & & & & ECO.134 & & & & LB. 26 & & & SEV.39 & & \\
\hline & & & & ECO.135 & & & & & & & & & \\
\hline \multirow{2}{*}{$\begin{array}{l}\text { Urban farming and } \\
\text { food }\end{array}$} & LEED.4 & & & ECO.8 & & & & & SMIS.39 & CGYM.37 & SEV.30 & & \\
\hline & LEED.30 & & & ECO.57 & & & & & & & & & \\
\hline \multirow[t]{3}{*}{ Natural resources } & LEED.12 & & CASBEE.12 & ECO.4 & & & & LB.1 & & CGYM.24 & & & \\
\hline & LEED.13 & & & & & & & & & & & & \\
\hline & LEED.14 & & & & & & & & & & & & \\
\hline \multirow[t]{3}{*}{ Species biodiversity } & LEED. 2 & BRE.51 & CASBEE.11 & & & & KIT.19 & LB. 22 & SMIS.38 & CGYM.28 & & & BIL.14 \\
\hline & & BRE.52 & CASBEE.14 & & & & & & & & & & \\
\hline & & BRE. 53 & & & & & & & & & & & \\
\hline \multirow{2}{*}{$\begin{array}{l}\text { Architectural } \\
\text { elements with } \\
\text { vegetation }\end{array}$} & & & & ECO.53 & & & & & & & & & \\
\hline & & & & ECO.62 & & & & & & & & & \\
\hline
\end{tabular}


Table S2.5. Classification of indicators in category "building and housing"

\begin{tabular}{|c|c|c|c|c|c|c|c|c|c|c|c|c|c|}
\hline \multirow[b]{2}{*}{ Subcategories } & \multicolumn{13}{|c|}{ Tools } \\
\hline & LEED ND & $\begin{array}{l}\text { BREEAM } \\
\text { Comm }\end{array}$ & $\begin{array}{l}\text { CASBEE } \\
\text { UD }\end{array}$ & ECOCITY & INDI-RU 2005 & BRDG & KITCASP & LB & SMIS & CGYM & SEV & $\mathrm{BCN}$ & BIL \\
\hline \multirow{2}{*}{$\begin{array}{l}\text { Fulfilment of } \\
\text { standards and } \\
\text { regulations }\end{array}$} & LEED.33 & BRE.60 & & & INDI.2 & & & & & & & & \\
\hline & LEED.37 & BRE.61 & & & INDI.36 & & & & & & & & \\
\hline \multirow{3}{*}{$\begin{array}{l}\text { Building renovation } \\
\text { and adaptation of } \\
\text { use }\end{array}$} & & BRE.62 & & ECO.68 & & & & & & & & & \\
\hline & & & & ECO.72 & & & & & & & & & \\
\hline & & & & ECO.74 & & & & & & & & & \\
\hline \multirow{4}{*}{$\begin{array}{l}\text { Building resource } \\
\text { efficiency }\end{array}$} & LEED.34 & & & & & & & & & & & & \\
\hline & LEED.35 & & & & & & & & & & & & \\
\hline & LEED.38 & & & & & & & & & & & & \\
\hline & LEED.39 & & & & & & & & & & & & \\
\hline \multirow{7}{*}{$\begin{array}{l}\text { Building energy } \\
\text { demand }\end{array}$} & & & & ECO.117 & & & & & & & & & \\
\hline & & & & ECO.118 & & & & & & & & & \\
\hline & & & & ECO.119 & & & & & & & & & \\
\hline & & & & ECO.120 & & & & & & & & & \\
\hline & & & & ECO.121 & & & & & & & & & \\
\hline & & & & ECO.122 & & & & & & & & & \\
\hline & & & & ECO.123 & & & & & & & & & \\
\hline \multirow{4}{*}{$\begin{array}{l}\text { Bioclimatic building } \\
\text { design } \\
\text { Diversity of housing }\end{array}$} & & & & ECO.69 & & & & & & & & & \\
\hline & & & & & INDI.50 & & & LB.13 & & & & & \\
\hline & & & & & INDI.51 & & & & & & & & \\
\hline & & & & & INDI.52 & & & & & & & & \\
\hline \multirow{3}{*}{$\begin{array}{l}\text { Maintenance of } \\
\text { buildings }\end{array}$} & & & & ECO.73 & & & KIT.7 & & & & & & \\
\hline & & & & ECO.182 & & & & & & & & & \\
\hline & & & & ECO.188 & & & & & & & & & \\
\hline
\end{tabular}


Table S2.6. Classification of indicators in category "energy"

\begin{tabular}{|c|c|c|c|c|c|c|c|c|c|c|c|c|c|}
\hline \multirow[b]{2}{*}{ Subcategories } & \multicolumn{13}{|c|}{ Tools } \\
\hline & LEED ND & $\begin{array}{l}\text { BREEA } \\
\mathrm{M} \\
\text { Comm }\end{array}$ & CASBEE UD & ECOCITY & $\begin{array}{l}\text { INDI- } \\
\text { RU } \\
2005\end{array}$ & BRDG & KIT & LB & SMIS & CGYM & SEV & $\mathrm{BCN}$ & BIL \\
\hline \multirow{2}{*}{$\begin{array}{l}\text { Sunlight and } \\
\text { shadows }\end{array}$} & LEED.31 & & CASBEE.17 & & & & & & & & SEV. 8 & & \\
\hline & LEED.46 & & CASBEE. 53 & & & & & & & & & & \\
\hline \multirow{9}{*}{$\begin{array}{l}\text { Bioclimatic urban } \\
\text { design }\end{array}$} & & & CASBEE.16 & ECO.10 & INDI.25 & BRDG.3 & & LB.12 & & CGYM.6 & SEV.9 & & \\
\hline & & & CASBEE. 40 & ECO.12 & & BRDG.9 & & LB.17 & & & & & \\
\hline & & & CASBEE. 52 & ECO.32 & & BRDG.5 & & LB. 45 & & & & & \\
\hline & & & & ECO.54 & & BRDG. 6 & & LB. 46 & & & & & \\
\hline & & & & ECO.59 & & BRDG.7 & & & & & & & \\
\hline & & & & ECO.60 & & & & & & & & & \\
\hline & & & & ECO.61 & & & & & & & & & \\
\hline & & & & ECO.114 & & & & & & & & & \\
\hline & & & & ECO.115 & & & & & & & & & \\
\hline \multirow[t]{3}{*}{ Urban heat island } & LEED.45 & BRE.4 & CASBEE.1 & & & BRDG.2 & & & & & & & \\
\hline & & & CASBEE. 2 & & & & & & & & & & \\
\hline & & & CASBEE. 3 & & & & & & & & & & \\
\hline \multirow{8}{*}{$\begin{array}{l}\text { Energy efficiency } \\
\text { of facilities and } \\
\text { monitoring }\end{array}$} & LEED.48 & BRE.5 & CASBEE.4 & ECO.21 & INDI.1 & & & LB. 47 & & & & & \\
\hline & LEED.49 & BRE.8 & CASBEE.18 & ECO.116 & INDI.3 & & & & & & & & \\
\hline & & BRE.11 & CASBEE.19 & ECO.124 & & & & & & & & & \\
\hline & & & CASBEE. 43 & ECO. 125 & & & & & & & & & \\
\hline & & & CASBEE. 68 & ECO.126 & & & & & & & & & \\
\hline & & & CASBEE.69 & & & & & & & & & & \\
\hline & & & CASBEE.71 & & & & & & & & & & \\
\hline & & & CASBEE. 81 & & & & & & & & & & \\
\hline \multirow[t]{5}{*}{ Renewable energy } & LEED.47 & BRE. 6 & CASBEE. 67 & ECO.9 & INDI.7 & BRDG.4 & KIT.16 & LB.48 & SMIS.20 & CGYM. 32 & & BCN.10 & BIL.4 \\
\hline & & BRE.7 & & ECO.22 & & & & & & CGYM. 33 & SEV. 25 & & \\
\hline & & & & ECO.127 & & & & & & & & & \\
\hline & & & & ECO. 128 & & & & & & & & & \\
\hline & & & & ECO.129 & & & & & & & & & \\
\hline \multirow[t]{3}{*}{ Energy supply } & & & CASBEE. 20 & & & & & LB.49 & & & & & \\
\hline & & & CASBEE. 21 & & & & & & & & & & \\
\hline & & & CASBEE. 22 & & & & & & & & & & \\
\hline \multirow{2}{*}{$\begin{array}{l}\text { Energy } \\
\text { consumption }\end{array}$} & & & CASBEE. 75 & & INDI.5 & BRDG.1 & & LB.44 & SMIS.19 & CGYM.31 & SEV.44 & BCN.7 & BIL.3 \\
\hline & & & & & INDI.6 & & & & & CGYM. 52 & & BCN.8 & \\
\hline
\end{tabular}

Table S2.7. Classification of indicators in category "water"

\begin{tabular}{|c|c|c|c|c|c|c|c|c|c|c|c|c|c|}
\hline \multirow[b]{2}{*}{ Subcategories } & \multicolumn{13}{|c|}{ Tools } \\
\hline & LEED ND & $\begin{array}{l}\text { BREEA } \\
\text { M } \\
\text { Comm }\end{array}$ & CASBEE UD & ECOCITY & $\begin{array}{l}\text { INDI-RU } \\
2005\end{array}$ & BRDG & KIT & LB & SMIS & CGYM & SEV & $\mathrm{BCN}$ & $\mathrm{BIL}$ \\
\hline \multirow[t]{2}{*}{$\begin{array}{l}\text { Water } \\
\text { consumption }\end{array}$} & LEED.40 & BRE.9 & & ECO.130 & INDI.9 & BRDG. 8 & & LB. 50 & SMIS.16 & CGYM.34 & SEV.26 & BCN.12 & BIL.1 \\
\hline & & & & & INDI.10 & & & LB.51 & & CGYM.36 & & BCN.13 & \\
\hline \multirow{6}{*}{$\begin{array}{l}\text { Rainwater and } \\
\text { wastewater } \\
\text { management }\end{array}$} & LEED.44 & BRE.3 & CASBEE.56 & ECO.131 & INDI.11 & & & LB.52 & SMIS.17 & CGYM.35 & & & \\
\hline & LEED.50 & & CASBEE.57 & ECO.132 & INDI.12 & & & LB.53 & SMIS.18 & & & & \\
\hline & & & CASBEE.58 & ECO.133 & INDI.13 & & & LB.54 & & & & & \\
\hline & & & CASBEE.59 & ECO.136 & & & & LB. 55 & & & & & \\
\hline & & & CASBEE.60 & ECO.140 & & & & LB.56 & & & & & \\
\hline & & & CASBEE.61 & & & & & LB.65 & & & & & \\
\hline \multirow[t]{3}{*}{ Water quality } & LEED.3 & BRE.16 & CASBEE. 8 & ECO.55 & & & KIT.20 & & & & & & BIL.2 \\
\hline & & & CASBEE. 9 & ECO.137 & & & & & & & & & \\
\hline & & & CASBEE.10 & ECO.138 & & & & & & & & & \\
\hline
\end{tabular}


Table S2.8. Classification of indicators in category "materials"

\begin{tabular}{|c|c|c|c|c|c|c|c|c|c|c|c|c|c|}
\hline \multirow[b]{2}{*}{ Subcategories } & \multicolumn{13}{|c|}{ Tools } \\
\hline & LEED ND & $\begin{array}{l}\text { BREEAM } \\
\text { Comm }\end{array}$ & CASBEE UD & ECOCITY & $\begin{array}{l}\text { INDI-RU } \\
2005\end{array}$ & BRDG & KIT & LB & SMIS & CGYM & SEV & $\mathrm{BCN}$ & BIL \\
\hline \multirow{6}{*}{$\begin{array}{l}\text { Low-impact } \\
\text { materials }\end{array}$} & & BRE.12 & CASBEE.41 & ECO.70 & & & & & & & & & \\
\hline & & & CASBEE. 42 & ECO.152 & & & & & & & & & \\
\hline & & & CASBEE.74 & ECO.154 & & & & & & & & & \\
\hline & & & CASBEE. 77 & & & & & & & & & & \\
\hline & & & CASBEE.70 & & & & & & & & & & \\
\hline & & & CASBEE. 78 & & & & & & & & & & \\
\hline \multirow{2}{*}{$\begin{array}{l}\text { Certified reference } \\
\text { materials }\end{array}$} & & & & & INDI.18 & & & & & & & & \\
\hline & & & & & INDI.19 & & & & & & & & \\
\hline \multirow{10}{*}{$\begin{array}{l}\text { Reused and recycled } \\
\text { materials }\end{array}$} & LEED.51 & & & ECO.71 & & & & LB.59 & & & SEV.29 & & \\
\hline & & & & ECO.112 & & & & LB.60 & & & & & \\
\hline & & & & ECO.147 & & & & LB.61 & & & & & \\
\hline & & & & ECO.149 & & & & & & & & & \\
\hline & & & & ECO.150 & & & & & & & & & \\
\hline & & & & ECO.151 & & & & & & & & & \\
\hline & & & & ECO.155 & & & & & & & & & \\
\hline & & & & ECO.156 & & & & & & & & & \\
\hline & & & & ECO.157 & & & & & & & & & \\
\hline & & & & ECO.158 & & & & & & & & & \\
\hline \multirow[t]{2}{*}{ Local materials } & & BRE.13 & CASBEE.33 & ECO.111 & & & & LB.58 & & & & & \\
\hline & & BRE.14 & & ECO.153 & & & & & & & & & \\
\hline
\end{tabular}

Table S2.9. Classification of indicators in category "waste"

\begin{tabular}{|c|c|c|c|c|c|c|c|c|c|c|c|c|c|}
\hline \multirow[b]{2}{*}{ Subcategories } & \multicolumn{13}{|c|}{ Tools } \\
\hline & LEED ND & $\begin{array}{l}\text { BREEAM } \\
\text { Comm }\end{array}$ & CASBEE UD & ECOCITY & $\begin{array}{l}\text { INDI-RU } \\
2005\end{array}$ & BRDG & KIT & LB & SMIS & CGYM & SEV & $\mathrm{BCN}$ & BIL \\
\hline \multirow{10}{*}{$\begin{array}{l}\text { Minimising waste } \\
\text { production } \\
\text { Waste treatment }\end{array}$} & & BRE.15 & & ECO.145 & & & & & SMIS.21 & & SEV. 28 & BCN.3 & BIL.17 \\
\hline & LEED.52 & & CASBEE. 62 & ECO.23 & INDI.42 & & & LB.62 & SMIS.22 & CGYM.38 & SEV.27 & BCN.4 & \\
\hline & & & CASBEE.63 & ECO.24 & INDI.43 & & & LB.63 & & CGYM.39 & SEV. 31 & BCN. 5 & \\
\hline & & & CASBEE.64 & ECO.25 & & & & LB.64 & & CGYM.40 & & BCN.6 & \\
\hline & & & & ECO.108 & & & & LB.66 & & CGYM.41 & & & \\
\hline & & & & ECO.141 & & & & LB. 67 & & CGYM.42 & & & \\
\hline & & & & ECO.142 & & & & LB.68 & & CGYM.43 & & & \\
\hline & & & & ECO.143 & & & & LB.69 & & & & & \\
\hline & & & & ECO.144 & & & & & & & & & \\
\hline & & & & ECO.146 & & & & & & & & & \\
\hline
\end{tabular}


Table S2.10. Classification of indicators in category "pollution"

\begin{tabular}{|c|c|c|c|c|c|c|c|c|c|c|c|c|c|}
\hline \multirow[b]{2}{*}{ Subcategories } & \multicolumn{13}{|c|}{ Tools } \\
\hline & LEED ND & $\begin{array}{l}\text { BREEAM } \\
\text { Comm }\end{array}$ & CASBEE UD & ECOCITY & $\begin{array}{l}\text { INDI- } \\
\text { RU } \\
2005 \\
\end{array}$ & BRDG & KIT & LB & SMIS & CGYM & SEV & $\mathrm{BCN}$ & BIL \\
\hline \multirow[t]{2}{*}{ Soil } & & BRE.17 & CASBEE.7 & ECO.65 & & & & & & & & & \\
\hline & & & CASBEE.44 & ECO.66 & & & & & & & & & \\
\hline \multirow[t]{4}{*}{ Air } & & & CASBEE.15 & ECO.64 & INDI.38 & BRDG.13 & KIT.17 & & SMIS.23 & CGYM.4 & & BCN.11 & BIL.11 \\
\hline & & & CASBEE.48 & ECO.5 & INDI.8 & BRDG.14 & & & SMIS.24 & CGYM.44 & & & \\
\hline & & & & & & BRDG.15 & & & & & & & \\
\hline & & & CASBEE. 51 & ECO.11 & INDI.37 & BRDG.16 & & & & & & & \\
\hline Water & & & & ECO.67 & & & & & & & & & \\
\hline \multirow[t]{3}{*}{ Noise } & & & CASBEE.49 & & INDI.39 & & & & SMIS. 25 & CGYM.5 & SEV.32 & & BIL.12 \\
\hline & & & CASBEE.50 & & INDI.40 & & & & & & & & \\
\hline & & & & & INDI.41 & & & & & & & & \\
\hline \multirow[t]{2}{*}{ Light } & LEED.53 & & CASBEE.54 & & & & & & & CGYM.45 & SEV.10 & & \\
\hline & & & CASBEE.55 & & & & & & & & & & \\
\hline \multirow{4}{*}{$\begin{array}{l}\text { Resources and } \\
\text { others }\end{array}$} & LEED. 36 & & CASBEE.46 & & & & & LB.70 & & & & & \\
\hline & & & CASBEE.76 & & & & & & & & & & \\
\hline & & & CASBEE.47 & & & & & & & & & & \\
\hline & & & CASBEE. 82 & & & & & & & & & & \\
\hline
\end{tabular}

Table S2.11. Classification of indicators in category "social aspect"

\begin{tabular}{|c|c|c|c|c|c|c|c|c|c|c|c|c|c|}
\hline \multirow[b]{2}{*}{ Subcategories } & \multicolumn{13}{|c|}{ Tools } \\
\hline & LEED ND & $\begin{array}{l}\text { BREEAM } \\
\text { Comm }\end{array}$ & CASBEE UD & ECOCITY & $\begin{array}{l}\text { INDI-RU } \\
2005\end{array}$ & BRDG & KIT & LB & SMIS & CGYM & SEV & $\mathrm{BCN}$ & BIL \\
\hline \multirow{6}{*}{$\begin{array}{l}\text { Social cohesion and } \\
\text { mixed } \\
\text { neighbourhoods }\end{array}$} & LEED.21 & BRE.24 & CASBEE. 36 & ECO.77 & INDI.44 & BRDG.25 & KIT.6 & LB.73 & SMIS.26 & CGYM.46 & & & BIL.25 \\
\hline & & & & ECO.159 & INDI.46 & & KIT.14 & & SMIS.27 & CGYM.47 & & & BIL.27 \\
\hline & & & & ECO.160 & INDI.73 & & KIT.15 & & SMIS.28 & CGYM.48 & & & BIL.30 \\
\hline & & & & ECO.161 & & & & & SMIS.29 & & & & BIL.31 \\
\hline & & & & & & & & & SMIS.31 & & & & \\
\hline & & & & & & & & & SMIS.37 & & & & \\
\hline \multirow[t]{3}{*}{ Citizen participation } & LEED.29 & BRE.48 & CASBEE.37 & ECO.162 & INDI.68 & & & LB. 85 & SMIS.36 & & & & BIL.26 \\
\hline & & BRE.49 & & ECO.163 & INDI.69 & & & & & & & & BIL.33 \\
\hline & & & & & INDI.70 & & & & & & & & \\
\hline \multirow[t]{2}{*}{ Civil association } & & & & ECO.38 & & & & LB.71 & & & & & \\
\hline & & & & & & & & LB.72 & & & & & \\
\hline \multirow[t]{4}{*}{ Affordable housing } & & BRE. 25 & & ECO.184 & & BRDG.26 & & LB.75 & & CGYM.49 & SEV.43 & & BIL.19 \\
\hline & & & & ECO.185 & & & & & & & & & \\
\hline & & & & ECO.187 & & & & & & & & & \\
\hline & & & & ECO.189 & & & & & & & & & \\
\hline Energy poverty & & & & ECO.186 & INDI.4 & & KIT.12 & & & & & & \\
\hline \multirow[t]{3}{*}{ Education } & & & & & INDI.53 & & KIT.11 & & & & & & \\
\hline & & & & & INDI.54 & & & & & & & & \\
\hline & & & & & INDI.55 & & & & & & & & \\
\hline
\end{tabular}


Table S2.12. Classification of indicators in category "economic aspect"

\begin{tabular}{|c|c|c|c|c|c|c|c|c|c|c|c|c|c|}
\hline \multirow[b]{2}{*}{ Subcategories } & \multicolumn{13}{|c|}{ Tools } \\
\hline & LEED ND & $\begin{array}{l}\text { BREEAM } \\
\text { Comm }\end{array}$ & CASBEE UD & ECOCITY & $\begin{array}{l}\text { INDI-RU } \\
2005\end{array}$ & BRDG & KIT & LB & SMIS & CGYM & SEV & $\mathrm{BCN}$ & BIL \\
\hline \multirow{3}{*}{$\begin{array}{l}\text { Local, social and } \\
\text { green jobs }\end{array}$} & & BRE.55 & & ECO.172 & INDI.71 & & & LB. 6 & & & & & BIL.21 \\
\hline & & & & ECO.173 & INDI.72 & & & LB.31 & & & & & BIL.22 \\
\hline & & & & ECO.174 & & & & LB.78 & & & & & \\
\hline \multirow[t]{3}{*}{ Employment rates } & & BRE.57 & & & INDI.45 & & KIT.1 & & SMIS.30 & & & & BIL.23 \\
\hline & & & & & INDI.47 & & KIT.2 & & SMIS.32 & & & & \\
\hline & & & & & INDI.57 & & & & SMIS.33 & & & & \\
\hline \multirow{2}{*}{$\begin{array}{l}\text { New business and } \\
\text { investment }\end{array}$} & & BRE.58 & & ECO.166 & & & KIT.4 & & & & & & \\
\hline & & & & ECO.168 & & & & & & & & & \\
\hline \multirow{2}{*}{$\begin{array}{l}\text { Quality of } \\
\text { employment }\end{array}$} & & BRE.56 & & ECO.169 & & & KIT.5 & & & & & & \\
\hline & & & & ECO.170 & & & & & & & & & \\
\hline Tourism & & & & & & & & & & & & & BIL.24 \\
\hline \multirow{3}{*}{$\begin{array}{l}\text { Return on } \\
\text { investment and } \\
\text { affordable costs }\end{array}$} & & & & ECO.176 & & & & & & & & & \\
\hline & & & & ECO.177 & & & & & & & & & \\
\hline & & & & ECO.178 & & & & & & & & & \\
\hline
\end{tabular}

Table S2.13. Classification of indicators in category "management and institution"

\begin{tabular}{|c|c|c|c|c|c|c|c|c|c|c|c|c|c|}
\hline \multirow[b]{2}{*}{ Subcategories } & \multicolumn{13}{|c|}{ Tools } \\
\hline & LEED ND & $\begin{array}{l}\text { BREEAM } \\
\text { Comm }\end{array}$ & CASBEE UD & ECOCITY & $\begin{array}{l}\text { INDI- } \\
\text { RU } \\
2005 \\
\end{array}$ & BRDG & KIT & LB & SMIS & CGYM & SEV & $\mathrm{BCN}$ & BIL \\
\hline \multirow{3}{*}{$\begin{array}{l}\text { Institutional } \\
\text { management }\end{array}$} & LEED.56 & BRE.50 & & ECO.180 & & & & LB.9 & & & & & \\
\hline & & & & ECO.181 & & & & LB.83 & & & & & \\
\hline & & & & & & & & LB. 87 & & & & & \\
\hline \multirow{7}{*}{$\begin{array}{l}\text { Process } \\
\text { management } \\
\text { Administrative } \\
\text { transparency }\end{array}$} & LEED.55 & & CASBEE.73 & & & & & & & & & & \\
\hline & & & & & & & & LB. 88 & & & & & \\
\hline & & & & & & & & LB.89 & & & & & \\
\hline & & & & & & & & LB.90 & & & & & \\
\hline & & & & & & & & LB.91 & & & & & \\
\hline & & & & & & & & LB.92 & & & & & \\
\hline & & & & & & & & LB.93 & & & & & \\
\hline \multirow{3}{*}{$\begin{array}{l}\text { Knowledge and } \\
\text { information } \\
\text { management }\end{array}$} & & & & ECO.171 & & & & LB. 81 & & CGYM.19 & & & \\
\hline & & & & & & & & LB.82 & & CGYM.22 & SEV.24 & & \\
\hline & & & & & & & & LB.84 & & & & & \\
\hline \multicolumn{14}{|l|}{$\begin{array}{l}\text { Information and } \\
\text { Communications }\end{array}$} \\
\hline Technology (ICT) & & & & & & & & & SMIS.35 & & & & \\
\hline \multirow{4}{*}{$\begin{array}{l}\text { Investment in } \\
\text { activities for society }\end{array}$} & & BRE.59 & & & & & KIT.3 & & & & & & BIL.15 \\
\hline & & & & & & & & & & & & & BIL.28 \\
\hline & & & & & & & & & & & & & BIL.29 \\
\hline & & & & & & & & & & & & & BIL.32 \\
\hline $\begin{array}{l}\text { Environmental } \\
\text { education }\end{array}$ & & & & ECO.96 & & & & LB. 86 & & & & & BIL.34 \\
\hline $\begin{array}{l}\text { Regulations to } \\
\text { improve }\end{array}$ & & & & ECO.104 & & & & & & & & & \\
\hline sustainability & & & & ECO.20 & & & & & & & & & \\
\hline
\end{tabular}


Table S2.14. Classification of indicators in category "innovation"

\begin{tabular}{|c|c|c|c|c|c|c|c|c|c|c|c|}
\hline \multirow[b]{2}{*}{ Subcategory } & \multicolumn{11}{|c|}{ Tools } \\
\hline & LEED ND & $\begin{array}{l}\text { BREEAM } \\
\text { Communit } \\
\text { ies }\end{array}$ & CASBEE UD & ECOCITY & $\begin{array}{l}\text { INDI-RU } \\
2005\end{array}$ & LB & SMIS & CGYM & SEV & $\mathrm{BCN}$ & BIL \\
\hline Innovation & LEED.54 & BRE.63 & & & & & & & & & \\
\hline
\end{tabular}

